\title{
Why has productivity growth stagnated in most Latin American countries since the neo-liberal reforms?
}

\author{
José Gabriel Palma ${ }^{1}$ \\ Cambridge Working Papers in Economics (CWPE) 1030
}

(Available at http://www.econ.cam.ac.uk/dae/repec/cam/pdf/cwpe1030.pdf)

\begin{abstract}
Latin America's economic performance since the beginning of neo-liberal reforms has been poor; this not only contrasts with its own performance pre-1980, but also with what has happened in Asia since 1980. I shall argue that the weakness of the region's new paradigm is rooted as much in its intrinsic flaws as in the particular way it has been implemented. Latin America's economic reforms were undertaken primarily as a result of the perceived economic weaknesses of the region - i.e., there was an attitude of 'throwing in the towel' vis-à-vis the previous state-led import substituting industrialisation strategy, because most politicians and economists interpreted the 1982 debt crisis as conclusive evidence that it had led the region into a cul-de-sac. As Hirschman has argued, policymaking has a strong component of 'path-dependency'; as a result, people often stick with policies after they have achieved their aims, and those policies have become counterproductive. This leads to such frustration and disappointment with existing policies and institutions that is not uncommon to experience a 'rebound effect'. An extreme example of this phenomenon is post-1982 Latin America, where the core of the discourse of the economic reforms that followed ended up simply emphasising the need to reverse as many aspects of the previous development (and political) strategies as possible. This helps to explain the peculiar set of priorities, the rigidity and the messianic attitude with which the reforms were implemented in Latin America, as well as their poor outcome. Something very different happened in Asia, where economic reforms were often intended (rightly or wrongly) as a more targeted and pragmatic mechanism to overcome specific economic and financial constraints. Instead of implementing reforms as a mechanism to reverse existing industrialisation strategies, in Asia they were put into practice in order to continue and strengthen ambitious processes of industrialisation.
\end{abstract}

Key words: Ideology, Neo-liberalism, Productivity, Employment, Investment, Income distribution, Rent-seeking, De-industrialisation, Catching-up, Export diversification

JEL classifications: B52, D31, E20, F13, F59, H54, J20, L50, N16, N36, 016, O40, P50

A shortened version of this paper will be published in J A Ocampo and J Ros (eds.), The Handbook of Latin American Economics, OUP.

1 September 2010. Faculty of Economics, Cambridge University. jgp5@cam.ac.uk. I would like to thank Anish Acharya, Stephanie Blankenburg, Ha-Joon Chang, Antonio David, Jonathan Di John, Samer Frangie, Jayati Ghosh, Daniel Hahn, Geoff Harcourt, Andre Hofman, Edward Hogan, Jorge Katz, Mushtaq Khan, Jan Kregel, Javier Núñez, José Antonio Ocampo, Isidoro Palma Matte, Guillermo Paraje, Carlota Pérez, Jonathan Pincus, Ignês Sodré, Lance Taylor and Damián Vergara for their helpful comments. Participants at several conferences and seminars also made helpful suggestions. Shortage of space in the Handbook means I shall be unable to review some of the relevant literature. The usual caveats apply. 
The business of historians is to remember what others forget.

Eric Hobsbawm

Today the appeal to newness, of no matter what kind, provided only that it is archaic enough, has become universal.

Theodor Adorno

If one of the Paretian optimum conditions cannot be fulfilled, a second best optimum situation is achieved only by departing from all other optimum conditions.

Richard Lipsey and Kevin Lancaster

Productivity isn't everything, but in the long run it is almost everything.

Paul Krugman

[Our recent past] demonstrates that the victory of the ideals of justice and equality

is always ephemeral, but also that [...] we can always start all over again [and again].

Leo Valiani

[Latin America] has a narcissistic tendency to use reality as a mirror for self-contemplation. [... Yet] human history is the product of discontent.

José Ortega y Gasset

\section{1.--Introduction}

Except for several commodities and a small number of other activities, Latin America's economic performance since the beginning of neo-liberal reforms has been poor; this not only contrasts with its own performance pre-1980, but also with what has happened in Asia. I shall argue that the weakness of the region's new paradigm is rooted as much in its intrinsic flaws as in the particular way it has been implemented. Keynes once said (discussing Say's Law) that Ricardo conquered England as completely as the Holy Inquisition conquered Spain; the same could be said for neo-liberalism in Latin America: it has conquered the region, including many in its left-wing intelligentsia, as completely (and fiercely) as the Inquisition conquered Spain. This process has been so successful that it has actually had the effect of 'closing the imagination' to conceptualising more progressive alternatives.

In Latin America (LA), the genesis of the new development strategy can be located in a series of negative external and domestic shocks c.1980, when the region was particularly vulnerable. As had happened in the 1930s, these laid the foundations for a radical ideological transformation that led to a new paradigm, this time along the lines of Anglo-Saxon neo-liberalism and US neo-conservatism. This was quite distinct from what was happening in Asia, where reforms were implemented in a much more pragmatic way.

Perhaps the key difference between LA and Asia is that in the latter most actors in favour of the reforms (including local capitalist élites, the administrative classes, and most intellectuals - even many in the 'new' left) have a different 
sense of national identity from their counterparts in LA; they also have a strong historical awareness, and their policy making is always firmly grounded in the real world. Nobody had to convince them that in reality there are so many distortions, market failures, coordination failures (especially in investment) and financial fragilities that when it came to policy-making the Washington Consensus's set of 'first-best' policies belongs to a fantasy world. And maybe they were also just cynical enough not to get too excited about an ideology (neoliberalism) that is based mostly on recycled $19^{\text {th }}$-century ideas wrapped in a narcissistic 'end of history' aura (Frangie and Palma, 2010). Also, in terms of 'modernity' in economic thinking, they probably did not need Adorno to remind them that: "Today the appeal to newness, of no matter what kind, provided only that it is archaic enough, has become universal." (2006; see epigraph to this paper). Or that: "Newness only becomes mere evil in its totalitarian format, where all the tension between individual and society, that once gave rise to the category of the new, is dissipated." So, in Asia one often finds the parallel existence of a seemingly fundamentalistic neo-liberal discourse (to appease the gods of the markets - or, rather, to appease those fake idols that at the moment seem constantly to be demanding worship, particularly in financial markets), with a more pragmatic, targeted and sometimes imaginative implementation of reforms. And an 'irreverent' pro-growth macro is never far away. ${ }^{2}$ In LA, instead, regarding the neo-liberal orthodoxy the aim of policy makers (including - and so far especially - those in the 'new' left) is not just the 'talking the talk', but the 'walking the walk' of that orthodoxy!

In fact, I sometimes wonder whether the unique brand of neo-liberalism bought by so many Latin Americans is just shorthand for 'nothing left to decide' - and in the case of the 'new' left, of course, 'nothing left to think about critically' (Palma, 2009a). Indeed, in most of the region the attitude today towards neoliberal economics, and in particular when it comes to policy-making, resembles Lord Kelvin's attitude towards physics at the end of the $19^{\text {th }}$ century (Kelvin, 1900). Then, he famously declared that in physics "there is nothing new to be discovered now. All that remains is more and more precise measurement. ${ }^{3}$

What characterises LA's economic reforms most is that they were undertaken primarily as a result of the perceived economic weaknesses of the region - i.e., there was an attitude of 'throwing in the towel' vis-à-vis the previous state-led import substituting industrialisation strategy (ISI). Basically, most politicians and economists interpreted the 1982 debt crisis as conclusive evidence that ISI had led the region into a cul-de-sac. As Hirschman has argued (1982), policy-making has a strong component of 'path-dependency'. As a result, people often stick with policies well after they have achieved their aims, and those policies have even become counterproductive. This leads to such frustration and disappointment with existing policies and institutions that is not uncommon to experience a 'rebound effect'. 4 An extreme example of this 'backlash' (or 'reverse shift') phenomenon is post-1982 LA, where economic

2 In Spain there is a saying that for a priest to become a bishop he needs to be a 'closet atheist'. Maybe in Asia many policy makers think that for their countries to become 'tigers' they have to follow a 'double play': on the one hand, to appear to play the globalisation game in full; on the other, in their policy-making practice, to think like neo-liberal atheists...

3 Lord Kelvin was one of the most important physicists of the 19th century, who played key roles in the development of thermodynamics, electric lighting and transatlantic telecommunication. He was buried next to Isaac Newton in Westminster Abbey.

4 Polanyi and Kalecki also wrote along similar lines; for an analysis of this issue, see Palma (2009c). 
reform ended up being mostly about the reversal of the previous development strategy - which, in many aspects, had overstayed its welcome.

From this perspective, what most differentiated LA from Asia was not just the strength with which the new neo-liberal ideology was adopted, but also the form in which the previous one (ISI) was given up. Hirschman called this "LA's tendency to fracasomania" (1982). So, perhaps it should not be surprising that the discourse of the reforms ended up resembling a compass whose 'magnetic north' was simply the reversal of as many aspects of the previous development strategy as possible - as Gustavo Franco (when President of Brazil's Central Bank) explained, the main task of economic reform in Cardoso's first government was "...to undo forty years of stupidity [besteira]..." (Veja, 15/11/1996). ${ }^{5}$ With this 'reverse-gear' attitude, this experiment in economic reform almost inevitably ended up as an exercise in 'not-very-creative-destruction'. This phenomenon was reinforced by the usual dynamic of idealisation: when there is an unremitting need to sustain the idealisation something (in this case, the neo-liberal economicreforms), what is needed is simultaneously to demonise something else (in this case anything to do with 'the past', especially the previous development strategy of state-led industrialisation). In fact, the more evident the flaws of what was idealised, the stronger the demonisation of the past had to be. ${ }^{6}$ This attitude towards 'the past' also leads to a peculiar sense of what is 'new' or 'modern', already mentioned above in the quotation from Adorno. And the mere idea that alternatives could exist increasingly met with a mixture of amusement and contempt. Franco again: "[The alternative now] is to be neo-liberal or neo-idiotic [neo-burros]." (Ibid.) And, of course, "burros" belong in (intellectual) Gulags.

In this respect, I would argue that perhaps one reason why 'pure' ideology is so important in LA (past and present) is because there is little else in the form of social cohesion. This helps to explain the peculiar set of priorities and the rigidity with which the reforms were implemented in $L A$, as well as their poor outcome, as distinct from many Asian countries - where economic reforms were implemented not as a messianic endeavour but (rightly or wrongly) as a more targeted and pragmatic mechanism to help lift specific pressing economic and financial constraints in order to continue and strengthen their existing ambitious industrialisation strategies.

LA is also a region whose critical social imagination has stalled. The emergence post-1950 of an intellectual tradition in the social sciences somehow runs against what one could call the 'Iberian tradition', which has been far more creative in painting, music, literature and film than in contributions to the social sciences. Basically, in the Iberian Peninsula social sciences have suffered due to a lack of 'enlightenment' beyond the arts and letters, and specifically the lack of sophistication in the state's exercise of power. Foucault's ideas can help understand this issue: knowledge and power are interrelated, one presupposing the other (Foucault, 2004). Foucault intended to show how the development of social sciences was interrelated with the deployment of more 'modern' forms of power (Frangie, 2008). But in the Iberian world, since states have often governed through 'un-modern' means, and at times via crudely mediated forms, they have not required much social knowledge, or sophistication in the forms of control. So, social sciences have been relegated to a relatively marginalised academic enterprise.

5 For Franco, the fact that Brazil's state-led ISI-industrialisation had delivered for most of those 40 years one of the fastest growth rates in the world was probably a mere detail of history.

6 For an analysis of the process of idealisation, see Sodré (2009). 
In essence, what has become manifest in the implementation of economic reforms in LA is how its brand of neo-liberalism - with its Anglo-Saxon fundamentalism and its Iberian 'minimalism' - has fitted perfectly with both its underlying power structure (and in particular with its perennial rent-seeking bias), and its lack of political need for more sophisticated forms of social imagination. Perhaps that also helps understand why this ideology was soon wrapped in an atmosphere of superiority, 'specialness' and contempt, not just for possible alternatives but also for everything that happened before (the past, even the recent past, acquired a growing sense of unreality). ${ }^{7}$

Ortega y Gasset once referred to LA's "...narcissistic tendency to use reality as a mirror for self-contemplation, rather than as a subject for critical analysis and progress". He also observed that in LA he found too many "selfsatisfied individuals", reminding them that "...human history is the product of discontent" (1918; see also epigraph). There's probably no better way to summarise what is wrong with LA's current ('Anglo-Iberian') neo-liberal paradigm and its political economy and policy-making than Ortega's observations, as (for reasons beyond the scope of this paper - see Palma, 2009a) these regional features have returned with a vengeance.

\section{2.-Latin America's poor growth performance post-1980: two main stylised facts}

\section{1.-The collapse of Latin America's growth rate post-1980 is unique in the Third World}

As is well known, the beginning of neo-liberal reforms instituted by Reagan and Thatcher was followed by a slowdown of the world economy. This was also associated with the complex transition from the 'mass-production-for-massconsumption' techno-economic paradigm to the age of information and telecommunications, with its more knowledge-intensive and flexible production techniques (Pérez, 2002). The average annual growth rate of the world economy fell from $4.5 \%(1950-1980)$ to $3.5 \%(1980-2008)$; and the median rate fell even further - from $4.7 \%$ to $3.1 \%$ (GGDC, 2009). However, LA's growth-rate collapse was extreme, even in this context (5.4\% to $2.7 \%)$.

The exception to the general slowdown was the 'third-tier' NICs (China, India, and Vietnam). Elsewhere in the developing world, the 'second-tier' NICs (Malaysia, Thailand, Indonesia) managed (on average) to keep their growth-rate stable despite the 1997 financial crisis, while in the 'first-tier' NICs (Korea, HongKong, Singapore, Taiwan), and in North Africa and Sub-Saharan Africa growthrates declined, but by a relatively small margin. LA, meanwhile, saw its growth rate halved. For example, if one ranks all countries of the database (excluding oil-exporting Middle Eastern countries) by GDP growth-rate (97 countries), Brazil's growth-ranking collapses from 10 (1950-1980) to 70 (1980-2008); in turn, Mexico's falls from 13 to 62 . What a contrast with China (43 to 1 ), India ( 72 to 7 ), and Vietnam (84 to 2)! Their divergent fortunes become evident in Figure 1.

\footnotetext{
7 As quoted in the epigraph, for Hobsbawm the business of historians is to remember what others forget. Today in LA this applies especially to economists.
} 


\section{FIGURE 1}

Brazil's GDP per capita as a multiple of India's GDP per capita, and Mexico's as a multiple of Vietnam's, 1950-2008

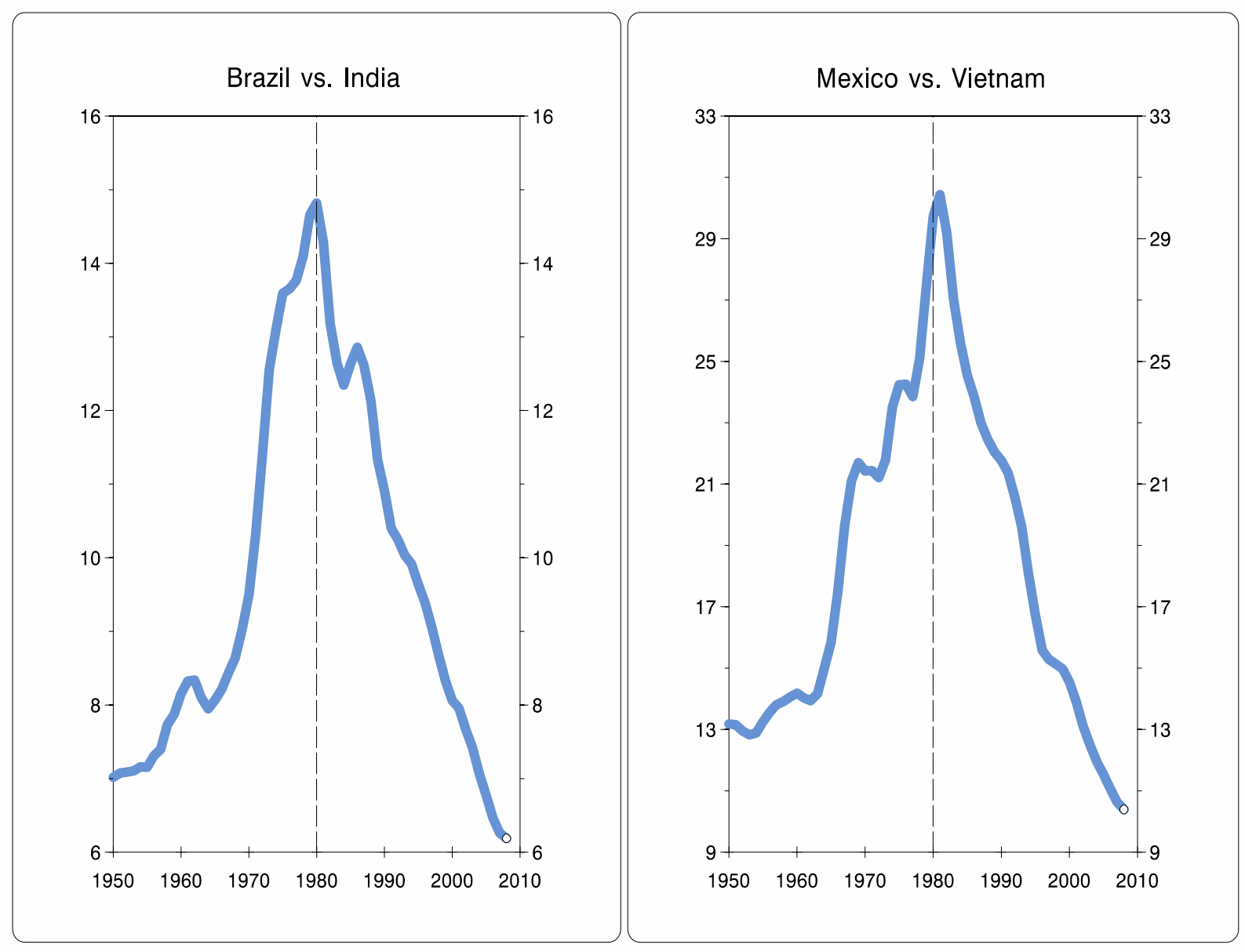

- Source: WDI (2010, data in constant 2000-US\$). The series were brought back to 1950 using GGDC (2009). 3-year moving averages.

Although from a Gerschenkronian (or Kuznetsian) perspective, one would have expected some catching-up by lower-income Asian countries, the extent of the post-1980 gains is truly remarkable - and China's catching-up is of course faster still. Figure 1 also confirms that (as opposed to what is usually argued) LA's relative growth weakness is not confined to the 1980s. Moreover, LA's disappointing post-1980 performance is fairly homogenous - see Figure 2. 
FIGURE 2

Latin America and other regions: GDP growth, 1950-1980 and 1980-2008

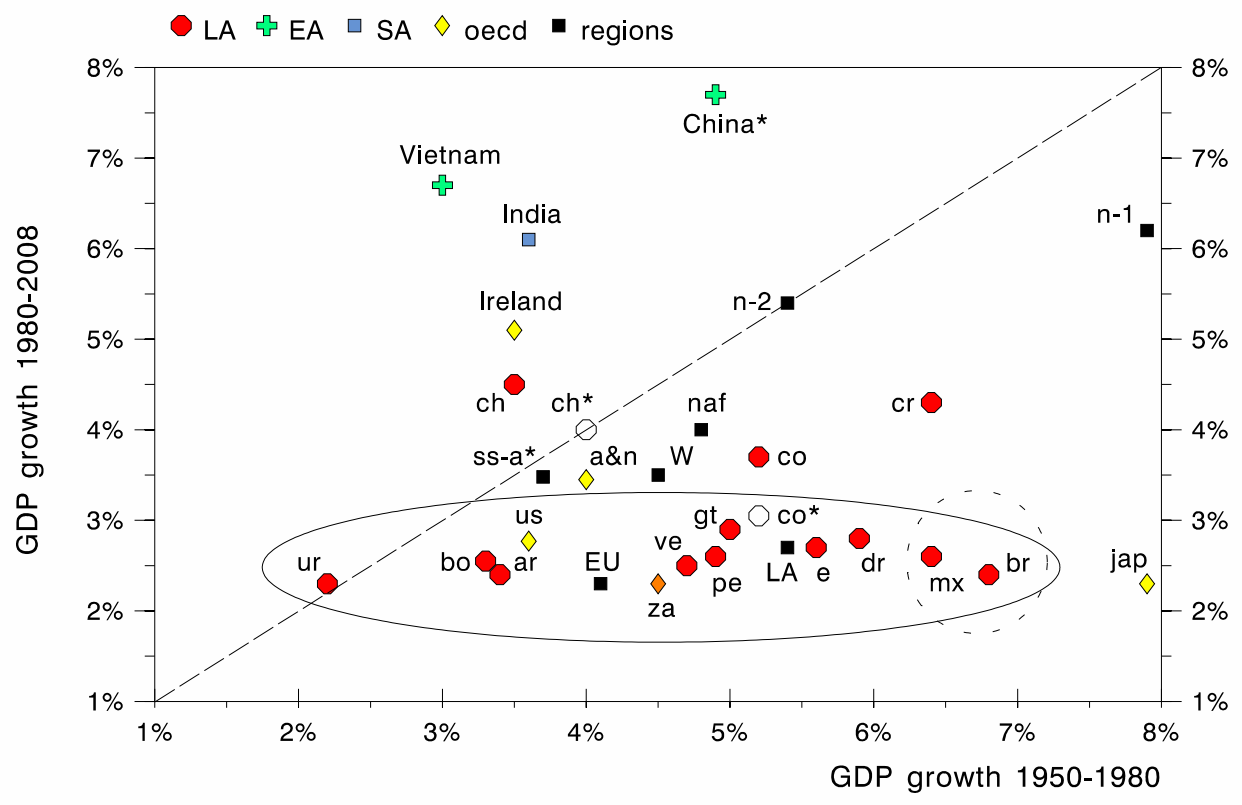

- Regions: $\mathbf{L A}=$ Latin America; $\mathbf{E A}=$ East and South East Asia; EU = European Union (excluding Germany because of unification); $\mathbf{n - 2}=$ second-tier NICs; naf = North Africa; SA = South Asia; ss-a* = Sub-Saharan Africa (excluding South Africa); and $\mathbf{W}=$ 'world' (weighted average for the 97 countries of the source).

- Countries: a\&n = Australia and New Zealand; ar = Argentina; $\mathbf{b o}=$ Bolivia; $\mathbf{b r}=$ Brazil; $\mathbf{c h}=$ Chile $\left(\mathbf{c h}^{*}=\right.$ Chile $1950-72$ and $1972-2008 ; 1972$ is chosen as a cutting year to avoid the distorting effect of 1973 , the year of the military coup); China*, rate of growth $1980-2008=8.5 \%$; co $=$ Colombia $\left(\right.$ co* $^{*}$ Colombia, second period 1980-2004); $\mathbf{c r}=$ Costa Rica; $\mathbf{d r}=$ Dominican Republic $\mathbf{e}=$ Ecuador $; \mathbf{g t}=$ Guatemala; $\mathbf{m x}=$ Mexico; $\mathbf{p e}=$ Peru; $\mathbf{u s}=$ United States; $\mathbf{u r}=$ Uruguay; $\mathbf{v e}=$ Venezuela $;$ and $\mathbf{z a}=$ South Africa (the rate of growth of the second period improves to $3.6 \%$ if restricted to 1994-2008). Unless otherwise stated, these acronyms will be used throughout the paper.

- Source: GGDC (2009, data in constant 1990-US\$, converted at Geary Khamis PPPs). The GGDC dataset only provides information for 13 Latin American countries (all included in the graph). Unless otherwise stated, this will be the source of all data on GDP, employment and labour productivity in this paper.

While between 1950 and 1980 the range of growth in LA was rather wide (from $2.1 \%$ [Uruguay] to $6.8 \%$ [Brazil]), in the latter period (1980-2008) 10 of the 13 countries of the database appear within a very narrow range - between $2.2 \%$ (Uruguay) and $2.9 \%$ (Guatemala). Furthermore, Colombia only emerged from this narrow range after 2004 (see 'co*'), leaving only Costa Rica and Chile properly outside this remarkably narrow band (growth-rates for 1980-2008 of $4.3 \%$ and $4.5 \%$, respectively).

Moreover, only Chile (and marginally Uruguay) managed to grow faster in the second period. In Chile, however, economic reforms began in 1973, so a more meaningful comparison would be between pre-1973-ISI and post-1973reform periods. In this case, the growth rate is actually the same in both (4\%; see 'ch*' in Figure 2). This Figure also confirms the remarkable growth-collapse of Brazil and Mexico - only Japan does worse. 


\section{2.-In Latin America the decline in GDP growth after 1980 was entirely absorbed by productivity, leaving the employment growth practically unaffected}

A comparison between Mexico and Thailand helps explain the second contrast between LA and Asia - now in terms of how a decline in GDP growth is absorbed differently by employment and labour productivity (Figure 3 ).

\section{FIGURE 3}

Mexico and Thailand: output, employment and productivity, 1950-2008

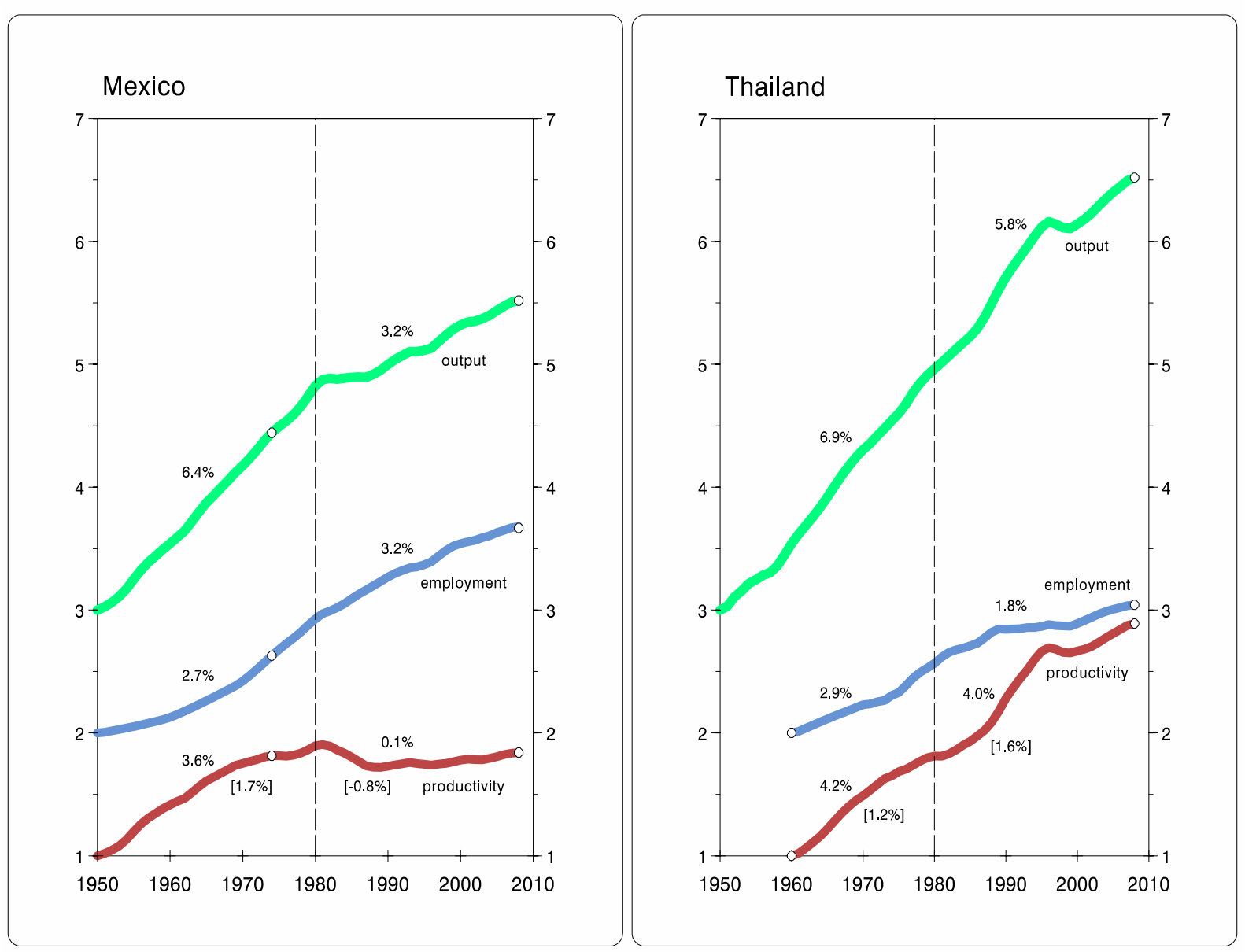

- Log scales and 3-year moving averages. Percentages above the lines are average annual real rates of growth for respective periods (Mexico, 1950-74 and 1974-2008 due to its different productivity cycle); those in brackets below the productivity lines indicate factor productivity (TFP) growth rates (due to lack of data, throughout this paper TFP rates are restricted to 1960-2004). For Thailand (and other Asian countries below), the first period in employment and productivity also starts in 1960 because for most Asian countries the GGDC database only provides employment data from that date.

- Source: as Figure 1; for TFP growth, see Figure 6 below.

If one divides these six decades into two periods, during the first there is little difference between the two countries in terms of their growth-rate of GDP $(6.4 \%$ and $6.9 \%$, respectively), employment $(2.7 \%$ and $2.9 \%)$, and labour productivity (3.6\% and $4.2 \%)$. This is clearly not the case afterwards: although both GDPs slowed, in Mexico this is totally absorbed by a decline in labour productivity (from $3.6 \%$ to $0.1 \%$ ), while in Thailand this is done by employment (from $2.9 \%$ to 
$1.8 \%$ ). So while Mexico's productivity growth collapses, employment creation actually accelerates (from $2.7 \%$ to $3.2 \%$ ) ${ }^{8}$ In contrast, Thailand's productivity growth continues at the same pace $(4.2 \%$ and $4 \%)$, and employment absorbs the fall in GDP growth (2.9\% and $1.8 \%$, respectively). Both countries have cycles and sectoral diversities, but in aggregate term the contrasting picture in terms of GDP 'shock-absorbers' is clear. And as Thailand has had little industrial policy, this asymmetry mostly reflects market outcomes. In fact, in Mexico, as the whole of GDP growth ends up being explained by additional employment, TFP growth becomes negative (and remains so after reforms; see Table 2 below). Table 1 shows that this contrast in terms of GDP 'shock-absorbers' also applies to the other countries of each region.

\section{TABLE 1}

\section{GDP, Employment, Labour Productivity and Gross Employment Elasticities, 1950-2008}

\begin{tabular}{|r|ccccccccc|}
\hline & \multicolumn{2}{|c}{ GDP } & \multicolumn{3}{c}{ Employment } & \multicolumn{2}{c|}{ L Productivity } & \multicolumn{2}{c|}{ Emp "Elast" } \\
\cline { 2 - 9 } & $1950-80$ & $80-2008$ & $1950-80$ & $80-2008$ & $1950-80$ & $80-2008$ & $1950-80$ & $80-2008$ \\
\hline China* & 4.9 & 8.5 & 2.4 & 1.7 & 2.0 & $\mathbf{6 . 7}$ & 0.5 & 0.2 \\
Vietnam* & 3.0 & 6.7 & 1.8 & 2.4 & 0.6 & $\mathbf{4 . 2}$ & 0.6 & 0.4 \\
N-1* & 8.1 & 6.2 & 3.7 & 2.0 & 5.0 & $\mathbf{4 . 2}$ & 0.5 & 0.3 \\
India* & 3.6 & 6.1 & 2.0 & 2.3 & 1.4 & $\mathbf{3 . 8}$ & 0.6 & 0.4 \\
N-2* & 5.4 & 5.4 & 2.4 & 2.3 & 3.5 & $\mathbf{3 . 0}$ & 0.5 & 0.4 \\
"World" & 4.4 & 3.7 & 2.0 & 1.6 & 2.4 & $\mathbf{2 . 1}$ & 0.4 & 0.4 \\
USA & 3.6 & 2.9 & 1.7 & 1.3 & 1.9 & $\mathbf{1 . 6}$ & 0.5 & 0.4 \\
EU & 4.1 & 2.3 & 0.5 & 0.8 & 3.6 & $\mathbf{1 . 5}$ & 0.1 & 0.4 \\
Australia \& NZ* & 4.0 & 3.3 & 2.1 & 1.8 & 1.9 & $\mathbf{1 . 5}$ & 0.5 & 0.6 \\
South Africa* & 4.5 & 2.3 & 2.8 & 1.2 & 1.7 & $\mathbf{1 . 1}$ & 0.6 & 0.5 \\
Latin America & $\mathbf{5 . 4}$ & $\mathbf{2 . 7}$ & $\mathbf{2 . 8}$ & $\mathbf{2 . 5}$ & $\mathbf{2 . 5}$ & $\mathbf{0 . 2}$ & $\mathbf{0 . 5}$ & $\mathbf{0 . 9}$ \\
\hline & & & & & & & & \\
Colombia & 5.2 & 3.7 & 3.1 & 2.2 & 2.0 & $\mathbf{1 . 4}$ & 0.6 & 0.6 \\
Chile & 3.5 & 4.5 & 1.4 & 3.1 & 2.1 & $\mathbf{1 . 4}$ & 0.4 & 0.7 \\
Costa Rica & 6.5 & 4.3 & 3.6 & 3.4 & 2.8 & $\mathbf{0 . 9}$ & 0.6 & 0.8 \\
Argentina & 3.4 & 2.4 & 1.2 & 2.0 & 2.1 & $\mathbf{0 . 4}$ & 0.4 & 0.8 \\
Brazil & 6.8 & 2.4 & 3.1 & 2.3 & 3.6 & $\mathbf{0 . 1}$ & 0.5 & 1.0 \\
Dom. Rep.* & 5.9 & 2.8 & 3.8 & 2.8 & 2.1 & $\mathbf{- 0 . 1}$ & 0.6 & 1.0 \\
Venezuela & 4.7 & 2.5 & 3.7 & 2.5 & 1.0 & $\mathbf{- 0 . 1}$ & 0.8 & 1.0 \\
Uruguay* & 2.1 & 2.2 & 0.6 & 2.2 & 1.6 & $\mathbf{- 0 . 1}$ & 0.3 & 1.0 \\
Mexico & 6.4 & 2.6 & 3.2 & 2.7 & 3.1 & $\mathbf{- 0 . 1}$ & 0.5 & 1.1 \\
Peru & 4.9 & 2.6 & 2.3 & 2.8 & 2.6 & $\mathbf{- 0 . 2}$ & 0.5 & 1.1 \\
Guatemala & 5.0 & 2.9 & 2.7 & 3.1 & 2.2 & $\mathbf{- 0 . 2}$ & 0.5 & 1.1 \\
Bolivia & 3.3 & 2.5 & 0.8 & 3.0 & 2.5 & $\mathbf{- 0 . 5}$ & 0.2 & 1.2 \\
Ecuador & 5.7 & 2.7 & 2.7 & 3.5 & 2.9 & $\mathbf{- 0 . 8}$ & 0.5 & 1.3 \\
\hline
\end{tabular}

- Countries and regions are ranked according to their 1980-2008 labour productivity growth rates. For those with ' $*$ ', for employment and productivity the first period rates are restricted to 1960-1980. L Productivity = labour productivity; Emp "Elast" = gross employment elasticities (understood simply as the ratio between employment growth and GDP growth); and $\mathbf{N Z}=$ New Zealand. 'World' excludes African countries as the source does not provide information on employment (and ILO, 2010 only provides information on African employment for a small number of years; furthermore, as for many African countries no real data exist, ILO estimates are based on econometric predictions).

- Sources: as Figure 1; and employment for South Africa, Quantec (2009).

8 There are well-known problems with employment data, especially in services (information on formal jobs is normally available, but those in the informal sector are often estimates). However, there is no reason to believe LA's employment statistics are any different than Asia's. 
Among the many issues arising from Table 1, four stand out vis-à-vis the first period (1950-80). First, pre-1980 only the 'first-tier' NICs (N-1) was doing better than LA in terms of GDP and employment. Second, LA's pre-1980 productivity growth was also relatively energetic $(2.5 \%)$; i.e., productivity doubling every 28 years, with Brazil and Mexico needing less than 20. Third, pre-1980 there was nothing special about LA's employment elasticities. And fourth, there was diversity within LA. However, post-1980 things changed sharply: while LA's GDP growth rate fell by half (becoming among the worst), its employment creation (by remaining stable) jumps to the top of the league. Consequently, its employment elasticity nearly doubles (from 0.49 to 0.92 , a level about twice most other countries'). And its labour productivity (growing at just $0.2 \%$ p.a.) sinks to the bottom.

A further comparison (Brazil vs. Korea), helps illustrate the above phenomenon (see Figure 4).

\section{FIGURE 4}

Brazil vs. Korea: labour productivity and 'catching up', 1950-2009 Labour productivity

'Catching up' with the US


- $\mathbf{L P}=$ labour productivity. Percentages on top are average annual real rates of productivity-growth during respective cycles (Brazil, 1950-1980, 1980-2003, and 20032009; Korea, 1960-1980, and 1980-2009). Those below in brackets indicate TFP growth rates in the same periods (although starting in 1960 in the first period, and finishing in 2004 in the second, as data necessary to construct TFP series are only available during these years; see Figure 7 below). 3-year moving averages.

- Source: as Figure 1; data were extended to 2009 using an update of the GGDC database (data in constant 2009-US\$, EKS PPPs). 
In terms of productivity, Brazil (as Mexico in Figure 3 above) was just about keeping up with Korea before 1980. In fact, by 1980 Brazil's overall productivity level was still higher (US\$19,713 and 17,184, respectively - data in constant 2009-US\$, EKS PPPs). And in terms of TFP (keeping in mind the problems associated with its concept and its measurement), before 1980 Brazil had a rate nearly three times higher than Korea. However, after 1980 the fortunes of these two countries moved in opposite directions: while Korea kept its productivity growth almost intact - and managed to double its TFP growth-rate - Brazil's productivity and TFP growth-rates collapsed to the point of becoming negative (the latter one highly negative). As a result, (and despite the post-2003 recovery in Brazil) by 2009 Korea's productivity was nearly 3 times higher than Brazil's (US $\$ 59,000$ and 21,900 ). So, while Korea was closing the productivity gap with the US very rapidly - up from $27 \%$ (1980) to $60 \%$ (2009) - Brazil was falling behind equally fast (but in a cyclical fashion) - down from $31 \%$ to $21 \%$ of US's productivity levels, respectively. ${ }^{9}$

\section{3.- Why is it so difficult for Latin America to sustain productivity growth (and TFP growth) for any significant length of time?}

\section{1.- Productivity growth in Latin American countries: an international perspective}

Perhaps the most significant stylised fact emerging from the above is that while Latin American countries are perfectly capable of generating periods of dynamic productivity growth (as evident in Brazil and Mexico for most of the 1950-1980 period, and in a few Latin American countries for short periods since then), they seem unable to sustain it long-term (Figures 5 and 6). Meanwhile, many in Asia mastered this technique quite nicely (Figure 6).

9 As has been widely reported (and evident in Figure 4), the Brazilian economy has moved into a more dynamic growth-cycle since 2003 (led mostly by a boom in commodities, finance and real estate), which was quickly resumed in 2010 after the 2009 slowdown (in part due to a pre-presidential election expenditure boom). As a result, productivity growth reached an annual rate of $1.9 \%$ between the starting point of the cycle (2003) and 2009. However, and despite a growing collective optimism in both Brazil and the financial press, there is so far little evidence that Brazil's current productivity-acceleration could be sustained and prove to be the exception to the above rule. 
FIGURE 5

Latin America (7): productivity growth, 1950-2008

Costa Rica, Ecuador, Guatemala and Colombia

Bolivia, Colombia and Dominican Republic
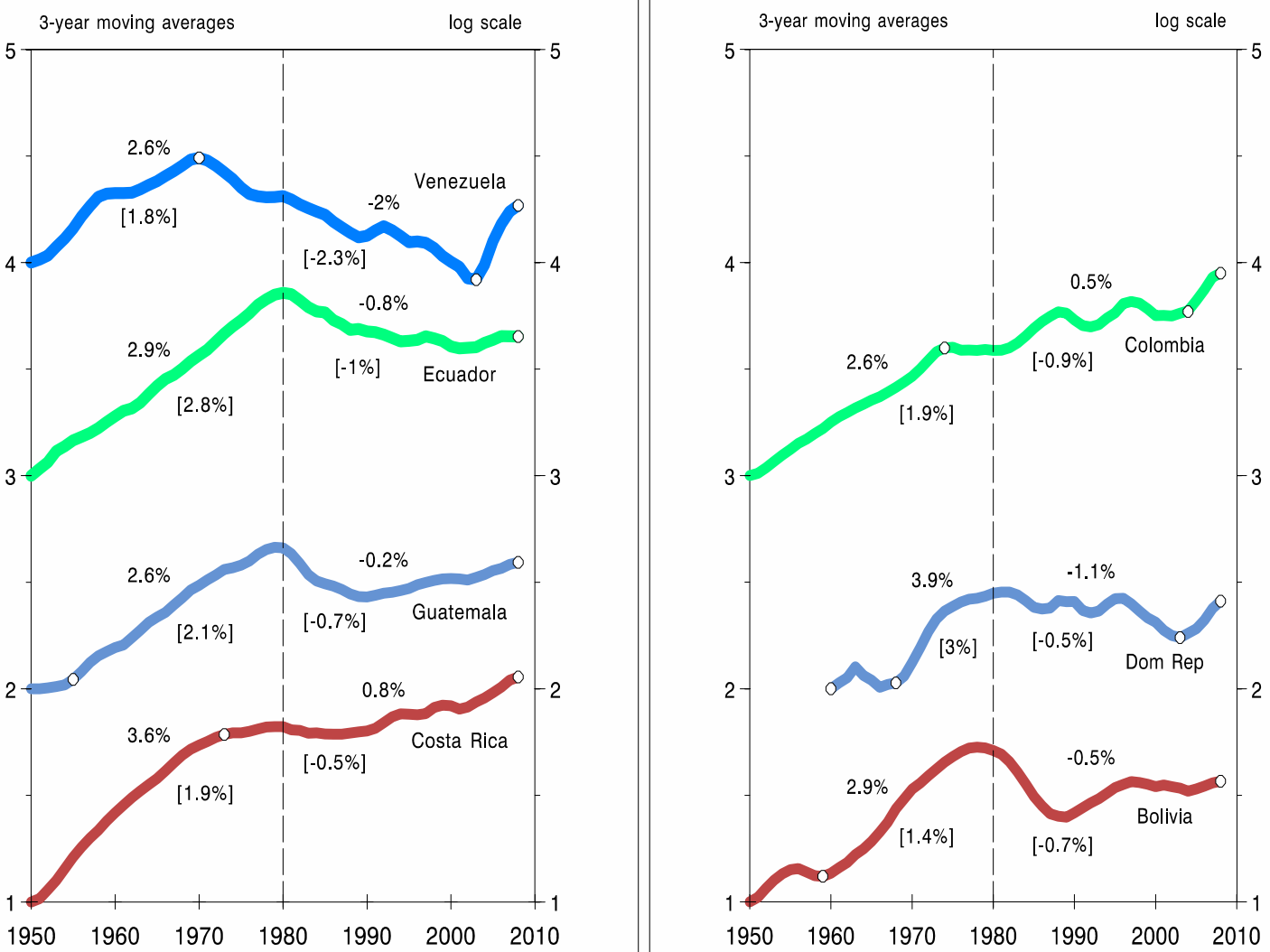

- Percentages above the lines are average annual real rates of productivity-growth during respective cycles. Those in brackets below the lines indicate TFP growth rates in the same periods (as in Figure 4; see also Figure 7 below). Dom Rep = Dominican Republic. 3year moving averages. 
FIGURE 6

Latin America (4) and Asia (3): productivity growth

Arg, Chile, Peru \& Urug: productivity growth, 1950-2008 Taiwan, China \& Indon: productivity growth, 1960-2008
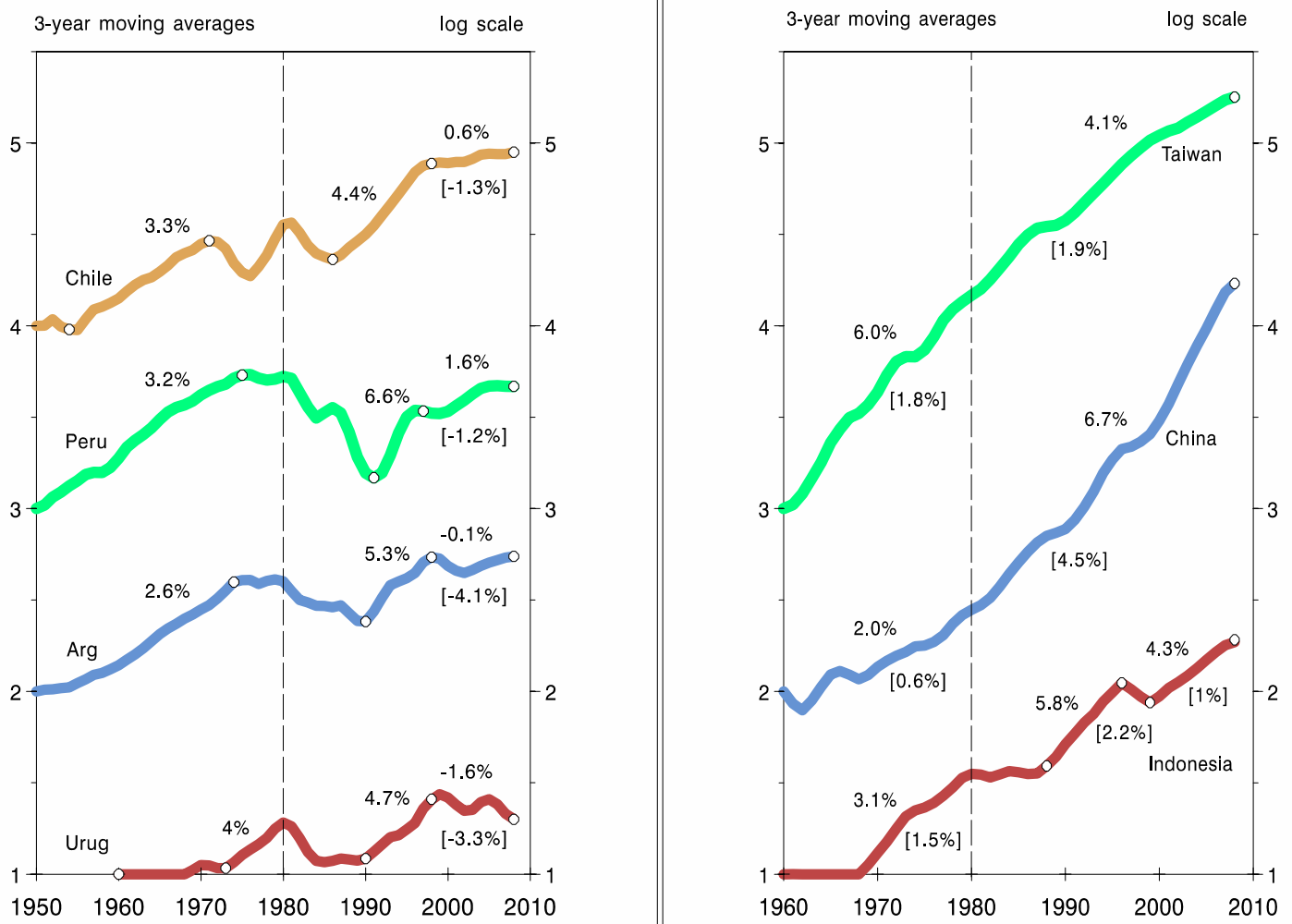

- Percentages above the lines are average annual real rates of productivity-growth during respective cycles; those in brackets below the lines indicate TFP growth rates between the end of the respective post-economic reform growth period and 2004 (last year for which TFP-data are availability). Arg = Argentina; and Urug = Uruguay .

The four Latin American countries of Figure 6 are included in this graph because (together with a few post-2003/2004 recoveries) they are the only ones in the region that experienced at least some years of rapid productivity growth after 1980. However, productivity growth in them all stopped abruptly after a relatively short period - and TFP growth became negative after that point (see also Figure 7). So, as far as productivity growth is concerned, if pre-1980 many LA countries were at least good middle-distance (productivity)-runners, post1980 they were at best good sprinters... Meanwhile many Asian tigers became top marathon-runners (a skill that crucially includes the ability to hold one's nerve more effectively in both sides of the economic cycle) - see Figure 6, right-hand panel.

The Chilean case is probably the most notable, in that its high productivity-growth period stopped abruptly in 1998 without having experienced a major financial crisis (as in Argentina) or political crisis (Peru). Chile needed only two relatively minor aftershocks (or contagion) from Asia (1997) and Russia (1998), and - this being LA - an over-reaction by its Central Bank (following the region's 'macho-monetarist' neo-liberal tradition). Subsequently productivity growth practically vanished $(0.6 \%$ between then and 2008$)$, becoming actually 
negative in 'per-hour-worked' terms $(-0.4 \%)$ - and even more so in TFP terms $(-1.3 \%) .{ }^{10}$ How different from the three Asian countries of Figure 6 (each representing one of the three NIC groups), or from other Asian countries that also managed rapid productivity growth during the near three decades between 1980 and 2008 , such as Korea (4.7\%), Vietnam (4.2\%), Thailand (4\%), India $(3.8 \%)$, Hong-Kong (3.4\%), Malaysia (3.3\%), Singapore (3.1\%), Sri Lanka (3.1\%), Bangladesh $(2.4 \%)$, or Pakistan $(2.9 \%)$, among others. LA's average for this period $(0.2 \%)$ seems to belong to a different world. Even if the 1980 s are excluded (due to LA's debt crisis and its aftermath), and the period is restricted to the post-reform 1990-2008 one, LA's average (1.3\%) is just a fraction of that of most Asian countries (China 8\%, Vietnam 5\%, India 4.2\%, Taiwan 4\%, Korea $3.9 \%$, Malaysia $3.7 \%$, Thailand $3.5 \%$, and so on).

Indonesia is included in Figure 6 (even though it is the least dynamic of the 'second-tier' NICs) because its experience is particularly relevant for a comparison with LA. Not only was it the hardest hit by the 1997 financial crisis, but also its whole post-independence history has been turbulent, plagued by natural disasters, separatism, poverty, genocide and corruption (the latter two especially during Suharto's three-decade-long presidency). Also, since the end of its oil-boom, Indonesia largely abandoned its (somewhat megalomaniac) industrial policy, and soon acquired a Latin-American-style proclivity for premature financialisation and monetarist-macro. ${ }^{11}$ Yet, no Latin American country has managed Indonesia's productivity growth-rate since 1990.

For those who consider TFP growth a more telling indicator of economic success (despite the major problems associated with its concept and its measurement), Figure 7 shows that in LA the contrasting picture between the two periods is even more striking.

\footnotetext{
10 Referring to these two contrasting periods, Michael Porter once said that Chile was like a two-act play; by then Chile was well into the second act, but most Chileans were still giving the first a standing ovation... Perhaps Ortega y Gasset would not have been surprised.

11 'Financialisation' is the rise in size and dominance of the financial sector relative to the non-financial sector, as well as the diversification towards financial activities in nonfinancial corporations.
} 


\section{FIGURE 7}

Latin America and five Asian economies: TFP (Hall and Jones), 1960-2004

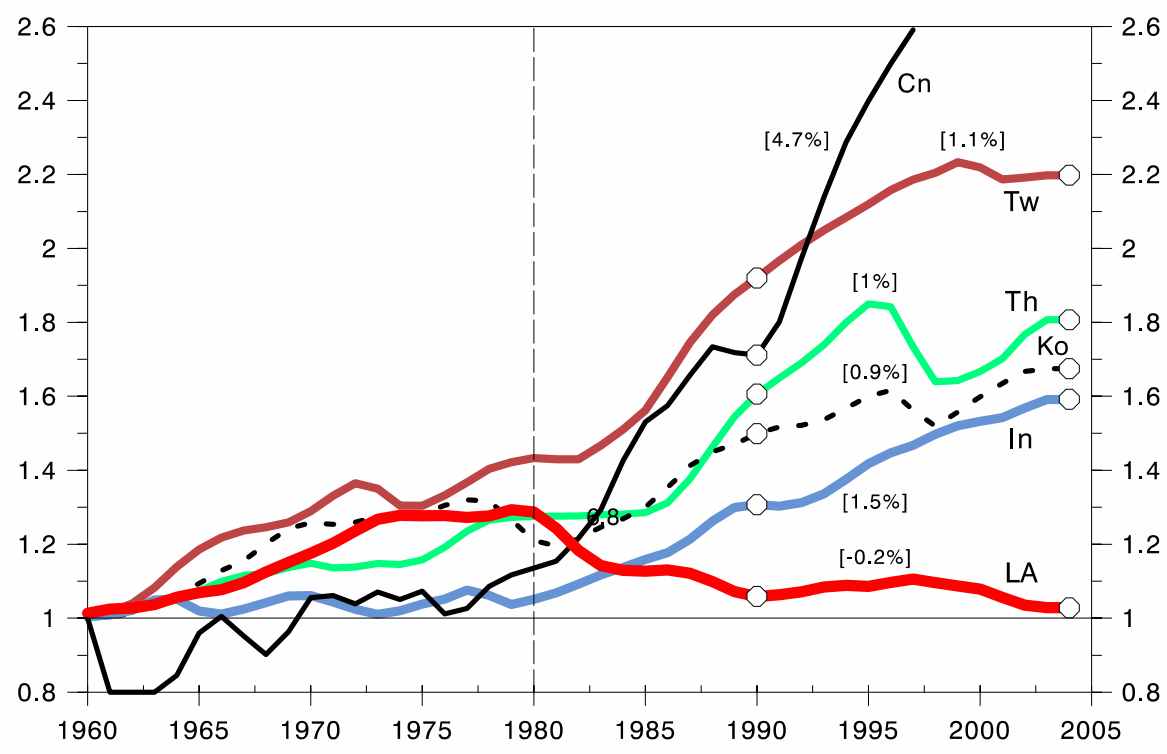

- $1960=1 . \quad$ Cn = China $(2003=3.12) ;$ In = India; Ko = Korea; Th = Thailand; and Tw = Taiwan. Percentages shown in the graph are TFP growth rates between 1990 and 2004 (i.e., the period of full-blown neo-liberal economic reform throughout Latin America). 3year moving averages.

- Source: Calculations made by Anish Acharya and author, using the Hall and Jones (1999) methodology for decomposing output per worker; data were available only until 2004 (2003 for some countries). Acharya (2009), and Palma (2010).

Much has been said regarding Krugman's 'TFP-critique' of East Asia (EA), as if the capacity to learn how to achieve rapid rates of factor accumulation (especially physical and human capital) could be dismissed as 'not the real thing'. However, Figure 7 and Table 2 show that even these more moderate Asian TFP-rates are well above LA's average post-1990 (i.e., post-economic-reform) performance. That was not the case with pre-1980 LA. 
TABLE 2

TFP growth: Latin America, Asia, South Africa and OECD, 1960-2004

\begin{tabular}{|r|rrr|r|rrr|} 
& $\mathbf{1 9 6 0 - 8 0}$ & $\mathbf{1 9 8 0 s}$ & $\mathbf{1 9 9 0 - 2 0 0 4}$ & & $\mathbf{1 9 6 0 - 8 0}$ & $\mathbf{1 9 8 0 s}$ & $\mathbf{1 9 9 0 - 2 0 0 4}$ \\
\cline { 2 - 2 } China & 0.6 & 4.2 & $\mathbf{4 . 7}$ & Chile & 0.5 & 0.7 & $\mathbf{1 . 4}$ \\
Ireland & 1.9 & 2.0 & $\mathbf{2 . 6}$ & D Republic & 1.0 & -1.8 & $\mathbf{1 . 0}$ \\
India & 0.2 & 2.5 & $\mathbf{1 . 5}$ & Costa Rica & 0.4 & -1.6 & $\mathbf{0 . 8}$ \\
Nordic & 1.0 & 0.8 & $\mathbf{1 . 1}$ & Argentina & 0.1 & -2.9 & $\mathbf{0 . 8}$ \\
Taiwan & 1.8 & 2.9 & $\mathbf{1 . 1}$ & Peru & 1.1 & -3.7 & $\mathbf{0 . 3}$ \\
Thailand & 1.2 & 2.4 & $\mathbf{1 . 0}$ & El Salvador & -0.7 & -2.4 & $\mathbf{0 . 3}$ \\
Australia & 1.2 & 0.2 & $\mathbf{1 . 0}$ & Brazil & 2.2 & -2.5 & $\mathbf{0 . 0}$ \\
Korea & 0.8 & 2.4 & $\mathbf{0 . 9}$ & Guatemala & 2.1 & -1.6 & $\mathbf{0 . 0}$ \\
Singapore & 1.2 & 1.4 & $\mathbf{0 . 9}$ & Uruguay & 1.4 & -1.5 & $\mathbf{- 0 . 1}$ \\
US & 0.8 & 0.8 & $\mathbf{0 . 8}$ & Nicaragua & -1.7 & -4.6 & $\mathbf{- 0 . 4}$ \\
Malaysia & 1.1 & 0.0 & $\mathbf{0 . 7}$ & Ecuador & 2.8 & -1.3 & $\mathbf{- 0 . 5}$ \\
World (84) & 1.2 & 0.7 & $\mathbf{0 . 7}$ & Mexico & 1.6 & -2.4 & $\mathbf{- 0 . 6}$ \\
New Zealand & 0.2 & 0.9 & $\mathbf{0 . 6}$ & Colombia & 1.9 & -1.1 & $\mathbf{- 0 . 6}$ \\
EU & 2.0 & 0.9 & $\mathbf{0 . 3}$ & Honduras & 0.6 & -1.2 & $\mathbf{- 1 . 1}$ \\
South Africa* & 1.7 & -2.1 & $\mathbf{0 . 1}$ & Paraguay & 1.9 & -1.8 & $\mathbf{- 1 . 3}$ \\
Latin America & $\mathbf{1 . 4}$ & $\mathbf{- 2 . 3}$ & $\mathbf{- 0 . 2}$ & Venezuela & -0.5 & -1.6 & $\mathbf{- 2 . 4}$ \\
\hline
\end{tabular}

- Countries/regions are ranked according to their TFP growth rates between 1990 and 2004. Nordic $=$ median Nordic country (Sweden); EU = median EU country excluding Nordic countries (Belgium); South Africa* = later period 1994-2004 (to reflect the period since the beginning of democracy and end to sanctions), and D Republic = Dominican Republic.

- Sources: as Figure 7.

With the exception of Chile, all LA posted negative TFP-rates during the 1980s, and in half of them TFP growth remained negative after 1990 and economic reform (and in two others is zero, and in another two practically stagnant). As a result, both during the 1980 s and the post-1990 reform-period LA's average is negative and well below everybody else's. That was clearly not the case between 1960 and 1980 - when only a few countries in the Mediterranean EU, Japan and Taiwan posted higher TFP growth rates than LA (and practically none higher than Brazil; see Table 2 and source). So, for those who follow the Washington Consensus, the most challenging question must be how was it that in most of LA TFP growth became negative (or at best stagnant) well after full-blown economic reform? And the well-rehearsed answer that what is needed is yet more of the same neo-liberal reforms sounds increasingly hollow.

\section{2.-Latin America's remarkably poor investment effort and its political economy}

There is little doubt that the core of LA's inability to sustain productivity growth after 1980 is its low rate of accumulation - poor even from the perspective of its relatively inadequate historical record (Figure 8, Panel A). 
FIGURE 8

Investment patterns in Latin America and Asia, 1950-2008

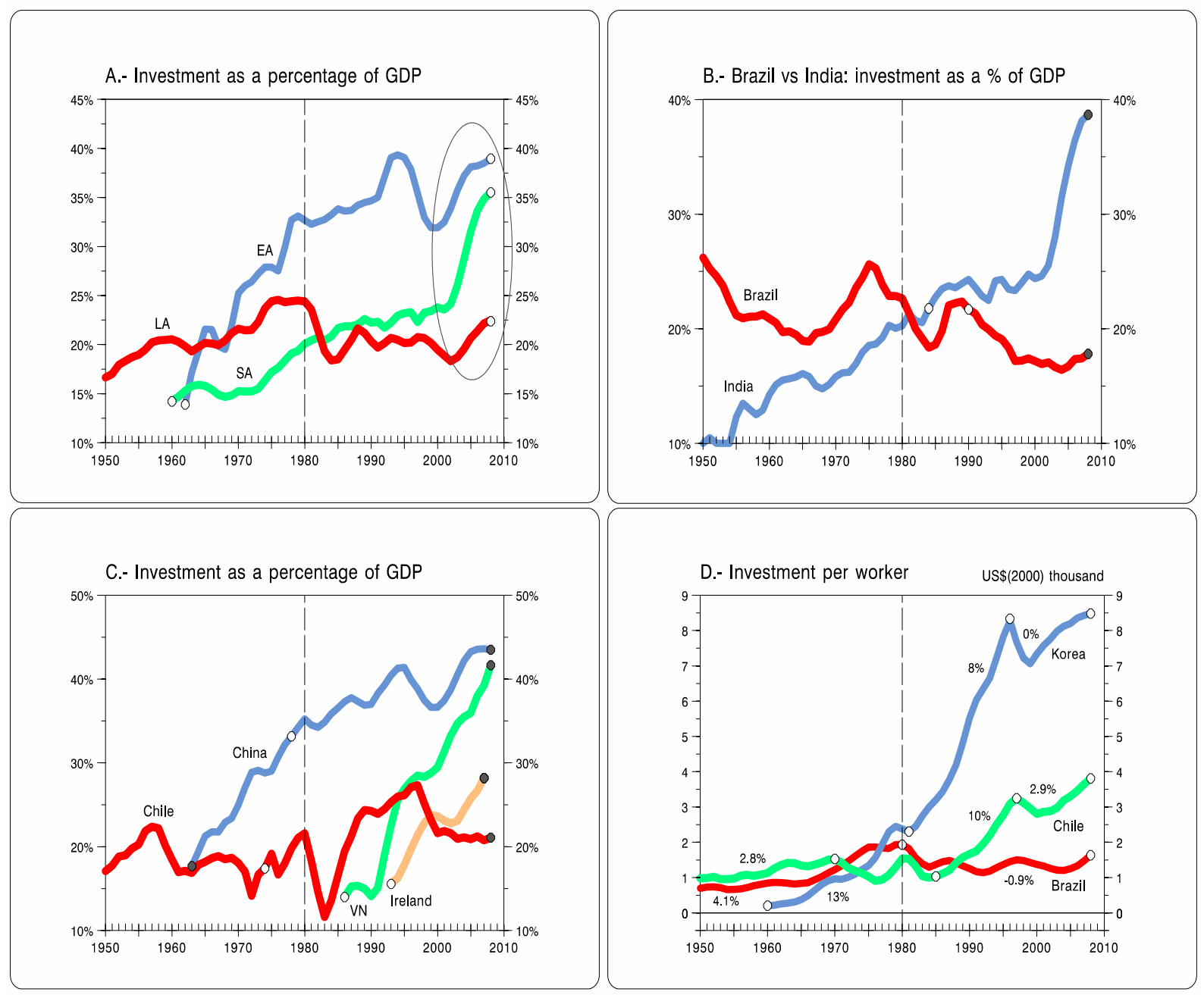

- In Panel B and C, white circles indicate the beginning of economic reform (for India, 1980; for Brazil, 1990 - Collor's 'New Brazil' Plan; fro Chile, 1973; for China, Deng Xiaoping's 1978 speech to the Third Plenary Session of the Party's Eleventh Central Committee; for Vietnam, 1986 - Doi moi; and for Ireland, 1993). For presentational purposes, Ireland is shown only from the beginning of economic reform. In Panel C, VN = Vietnam. In Panel D, percentages shown in the graph are growth rates in the respective periods (for Brazil, 1950-1980 and 1980-2008; for Chile, 1950-70, 1985-98 and 1998-2008; and for Korea, 1960-80, 1981-97 and 1997-2008. 3-year moving averages.

- Sources: for investment, WDI (2010); for investment in LA before 1960, CEPAL (2010); in India (http://mospi.gov.in/). For employment, GGDC (2009).

In Panel A, while investment-rates in EA and South Asia (SA) are stationary around a positive trend, LA's rate is stationary around a (low) intercept. ${ }^{12}$ It is fairly obvious that LA's capitalist élite has a preference for both sumptuous consumption, and for accumulation via mobile assets (financial ones and capital flight) rather than via 'fixed' capital formation. ${ }^{13}$ And neo-liberal reforms -

12 Due to space constraints, these and some other statistics below are not reported here; see Palma (2010a). In the case of SA, the investment-rate is stationary around a positive trend only until 2003 (due to India's investment surge after that date).

13 At least easy access to mobile assets helps oligarchies become more democratic... (See 
despite all their efforts towards defining and enforcing property rights, and many other 'market-friendly' policies aimed at incentivising investment - have had little impact on that. Even the small increase in investment during the surprisingly positive environment after $9 / 11$ (particularly in terms of access to finance and terms of trade) is unremarkable vis-à-vis those of Asia (see Panel A). Basically, in LA between 2002 and 2007 while the ratio of the stock of financial assets to GDP jumped from $106 \%$ to $182 \%$, the investment rate only improved from $19 \%$ to $22 \%$ (see IMF, 2009). Not much evidence here of the supposed revitalising effects of 'financial-deepening' promised by McKinnon and Shaw.

In essence, no theory of investment seems to be able to explain LA's stationarity-around-a-low-intercept behaviour, especially taking place during such a long period, such diverse domestic and international scenarios, and through such divergent development strategies. In turn, Panel B shows that in Brazil (like the rest of LA) economic reform seems to have unleashed more powerfully the predatory and rentier instincts of the region's capitalist élites (the former especially during the privatisation period) rather than their Schumpeterian ones. In India, as in many other Asian countries, meanwhile, reforms, especially partial financial liberalisation, may have brought complex challenges to the macro and the inevitable financial fragilities (as well as 'flexible' labour markets, increased inequalities, and so on), but at least in these Asian countries the rate of accumulation increased after their implementation. ${ }^{14}$ In LA, meanwhile, the cloud did not even have that silver lining. The contrast between Brazil and India in panel $B$ is particularly telling.

Furthermore, in the very few cases in LA where investment actually increased after reforms, as in Chile (Panel C), it is not obvious why it took so long for it to happen (over ten years after the beginning of reforms), let alone why it ran out of steam so easily afterwards (post-1998). Panel D indicates a similar difference in terms of investment per worker. While in Chile, at least for a time, this statistic shows dynamic growth, in Brazil (and despite the post-2003 recovery) by 2008 investment per worker was still $22 \%$ below that of 1980 (US $\$ 1,634$ and 2,106, respectively - data in constant 2000-US\$). On average, LA as a whole follows a pattern similar to Brazil's, with its 2008 level still below that of 1980. An extreme example is post-1980 Mexico (not in the graph): despite the highest level of FDI per worker in the world, by 2008 its investment per worker still had not recovered its 1980/1981 level. By then, and despite 1997, Korea had a level 3.6 times higher, and Malaysia and Thailand 2.2 times higher. In turn, China's 2008 level was 12 times higher; India's 4.5; and Vietnam had more than trebled this statistic since 1994 (first year that data are available for this country).

Perhaps from this perspective the contrasting productivity growth performance of LA and many in Asia - and the inability of LA to sustain productivity growth - are not that difficult to explain after all... In Brazil, for example, when between 1965 and 1980 investment per worker grew at an annual rate of $6.8 \%$, productivity grew at East Asian levels (4.3\%). Then, when investment per worker subsequently collapsed, productivity stagnated - its average rate of growth between 1980 and 2004 dropped to $-0.2 \%$. Finally, when investment per worker began to increase again (6.9\% between 2004 and 2008), productivity growth improved to $2.3 \%$ (2004-2009).

However, what is still unclear is why (despite the huge share of national income appropriated by the top earners, well-defined and enforced propertyrights, and 'pro-market' reforms) every time private investment in LA manages to

specially Boix, 2003).

14 The same is true, among others, for Korea, Malaysia and Thailand (not included in Panels B or C). 
rise much above $15 \%$ of GDP its capitalist élite starts experiencing feelings of vertigo (see Figure 9). From this perspective, the most striking difference between LA and Asia is found in their contrasting relationships between investment and income distribution.

\section{FIGURE 9}

Private Investment as a percentage of the income share of the top decile, c. 2007

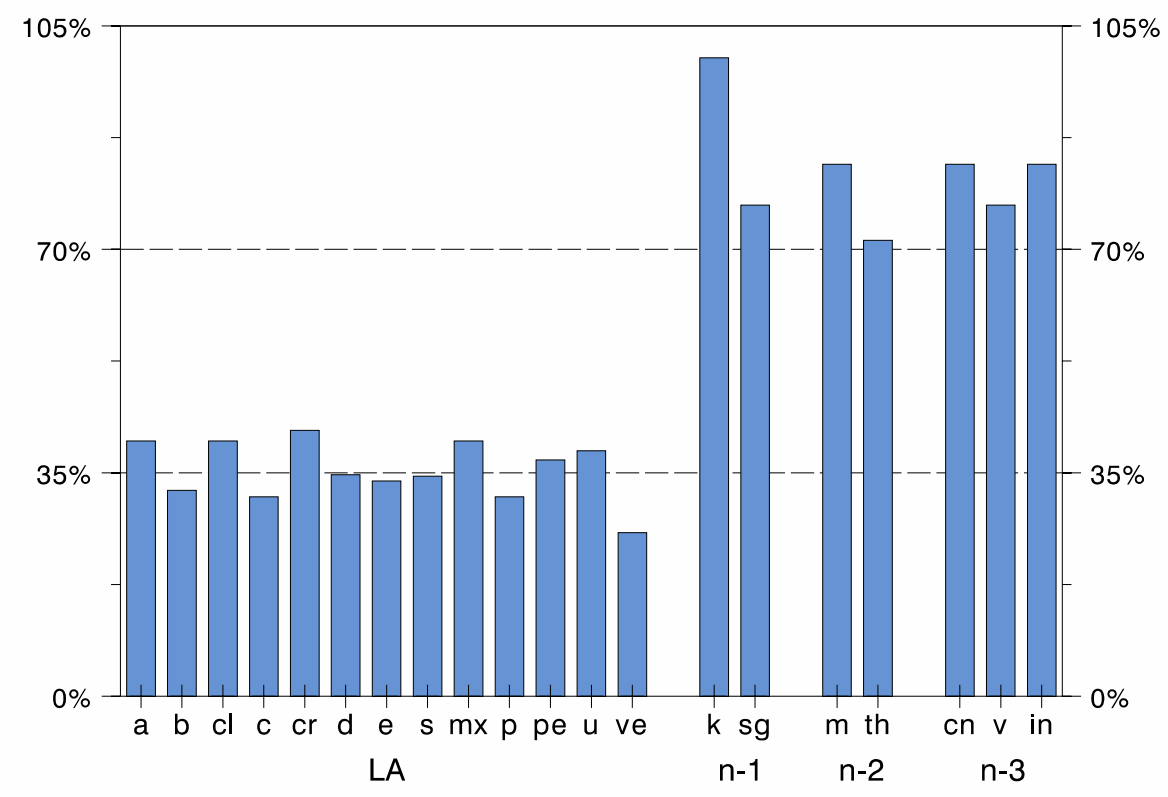

- Sources: for income distribution, WDI (2010); for private investment IMF (2010). $\mathbf{n - 3}=$ third-tier NICs (China, India and Vietnam), and $\mathbf{a}=$ Argentina; $\mathbf{b}=$ Brazil; $\mathbf{c l}=$ Chile; $\mathbf{c}=$ Colombia; $\mathbf{c r}=$ Costa Rica; $\mathbf{d}=$ Dominican Republic; $\mathbf{e}=$ Ecuador; $\mathbf{s}=\mathrm{El}$ Salvador; $\mathbf{m x}=$ Mexico; $\mathbf{p}=$ Paraguay $; \mathbf{p e}=$ Peru; $\mathbf{u}=$ Uruguay; $\mathbf{v e}=$ Venezuela; $\mathbf{k}=$ Korea; $\mathbf{s g}=$ Singapore; $\mathbf{m}=$ Malaysia $; \mathbf{t h}=$ Thailand; $\mathbf{c n}=$ China; $\mathbf{v}=$ Vietnam; $\mathbf{i n}=$ India.

It is often acknowledged that the only historical legitimacy of capitalism - i.e., the legitimacy of a small élite to appropriate such a large proportion of the social product - rests on the capacity of its élite to develop society's productive forces. And they can do so mainly by reinvesting most of that huge share. So, no other statistic seems to reflect so neatly the difference in the nature of capitalism in LA and most of Asia than that of Figure 9 - while in LA this ratio hovers around $35 \%$, in most of Asia it has a value of at least double that level, with Korea's above $1 !^{15}$

15 In South Africa (in this respect, LA's honorary middle-income country in Africa), and in The Philippines (the honorary one in Asia) similar low ratios as those of LA for private investment as a proportion of the income share of the top decile indicate that their capitalist élites have the same Latin preference for having their cake and eating it... Also, as discussed in detail in Palma (2009c), it seems that now with globalisation there is some 'Latin-contagion' going around, as LA is now exporting some crucial features of its political settlement and distributional outcome to the US (see Palma, 2009c). In the latter country, private investment as a percentage of the income share of the top decile has fallen from 
Figure 10 shows one of the key components of the poor investment effort in LA after neo-liberal reforms - the collapse of public investment.

\section{FIGURE 10}

\section{Latin America and other developing regions: public investment as a share of GDP, 1970-2009}
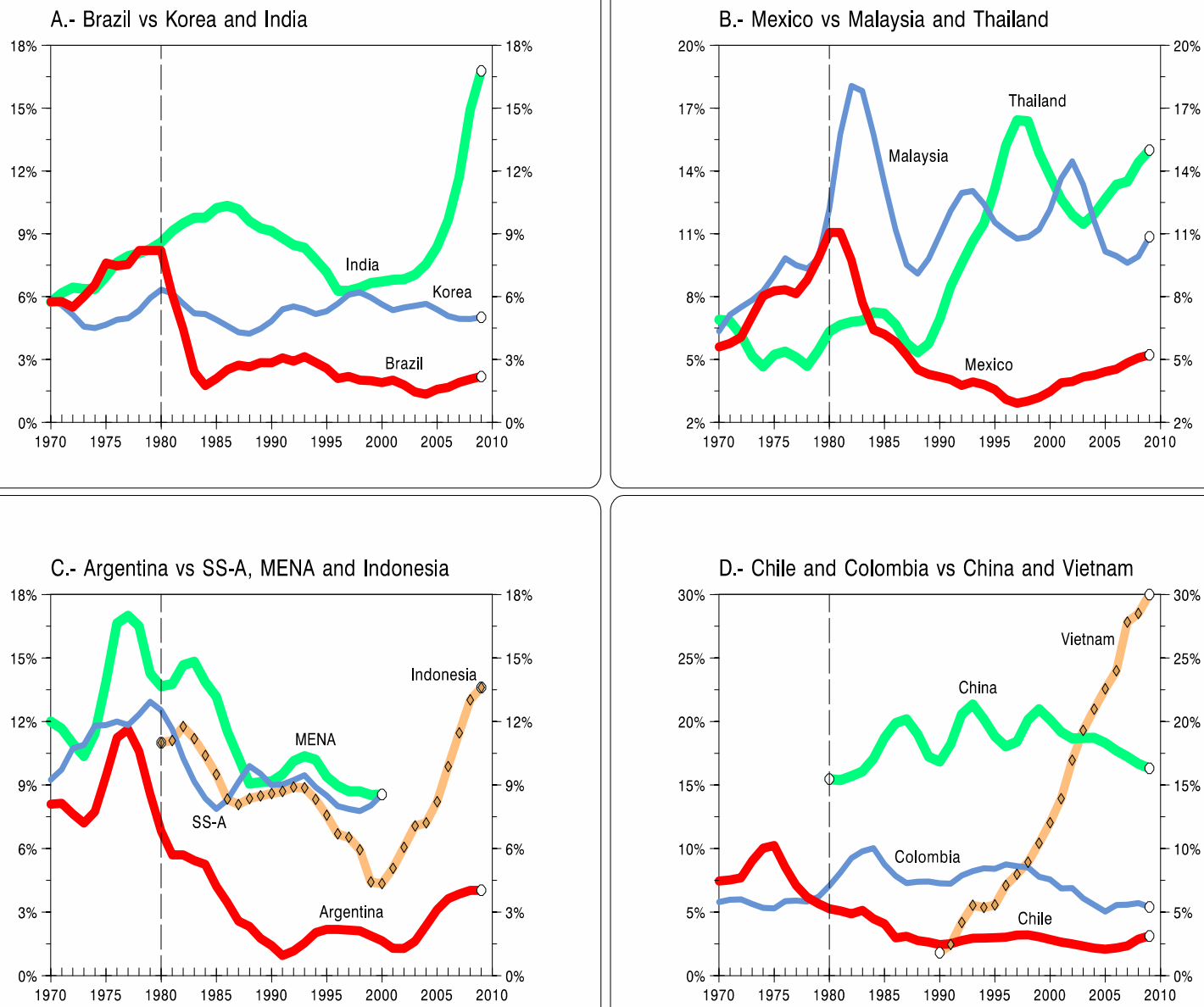

D.- Chile and Colombia vs China and Vietnam

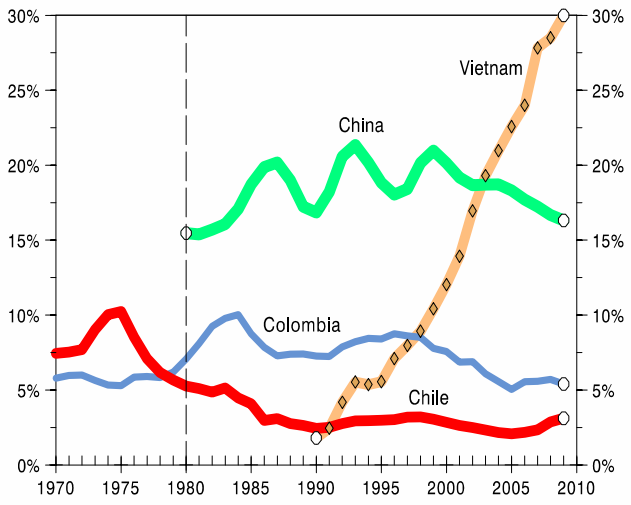

- Panel C, MENA = Middle East and North Africa. 3-year moving averages; current prices.

- Sources: for countries, IMF (2010; data for China and Indonesia only available from 1980, and for Vietnam from 1990). For regions, WB (2002); data available only until 2000).

One of the stated aims of neo-liberal reform in LA (but certainly not in Asia) is tying the hands of governments in terms of their capacity to create (what the mainstream likes to call) 'artificial' rents. In LA, however, neo-liberal reforms has only succeeded in tying government hands in terms of public investment - as it left its squeeze as the only mechanism to square public finances. Meanwhile, all

about half (before 1980s' Reagan) to a more relaxed Latin level of about a third. Also, what happened in Florida during the 2000 presidential election maybe was just the sign of things to come, as the electoral fraud engineered there could have come straight from the PRI's toolbox... In other words, and as opposed to Marx's prediction, now it is the less developed countries that seem to be showing the more industrialized ones the image of their own future. 
sorts of 'growth-hindering' rents (such as those resulting from lack of proper competition policy) and corruption continued unabated. Basically, a low (and remarkably regressive) tax intake - on average, less than half the OECD level in terms of share of GDP - and an emphasis on balanced budgets left little room for public investment. ${ }^{16}$ In some countries, especially Brazil, there was the added problem of servicing a huge public debt - a debt acquired mostly as a result of the mismanagement of financial reforms (see Palma, 2006). Unsurprisingly, crumbling infrastructure and shortages of complementary capital have become major constraints for growth. So, as Figure 10 indicates, the collapse in public investment took place as much in economies with relatively high tax intake (Brazil) as in those where this was low (Mexico, with just 12\% of GDP for non-oil taxes). In fact, Colombia, with the lowest tax collection among the major economies, had a slightly higher rate of public investment. Chile at least invested in infrastructure via 'private concessions'.

\section{3.-The crucial relationship between investment and productivity growth: the economy's engine-room}

The most robust statistical relationship between the growth of investment and productivity is found between non-residential investment per worker and productivity per hour worked. Not only is there a strong correlation between the two (stationary) series, but also (via an autoregressive distributed lag model that allows for more complex dynamics in the data) investment is found to have a large - and highly significant - impact multiplier. In Brazil, for example, during the period $1960-2008$ the $R^{2}$ is $68 \%$, and the impact multiplier is 0.4 (with a ' $t$ ' statistic of 9 ).

Figure 11 summarises the related growth cycle in two economies with at least one period of (Asian-pace) dynamic growth: Brazil (1964-1980), and Chile $(1986-1998) \cdot{ }^{17}$

\footnotetext{
16 In many Latin American countries, taxation is not just low, but it is so regressive that income distribution ends up being even more unequal after taxes. In the European Union, meanwhile, the GINI index improves by a range between 18 to 22 percentage points when taxes and all forms of government transfers are taken into account. In LA, instead, the GINI index improves at best by 2 percentage points; see Goñi, et. al. (2009). See also Di John (2007 and 2009).

17 In Chile, I have chosen 1986 as the starting date of the high growth period because after the 1982 crisis the economy only recovered its pre-1982 level of GDP in 1987.
} 
FIGURE 11

Brazil and Chile: investment and productivity paths, 1950-2008
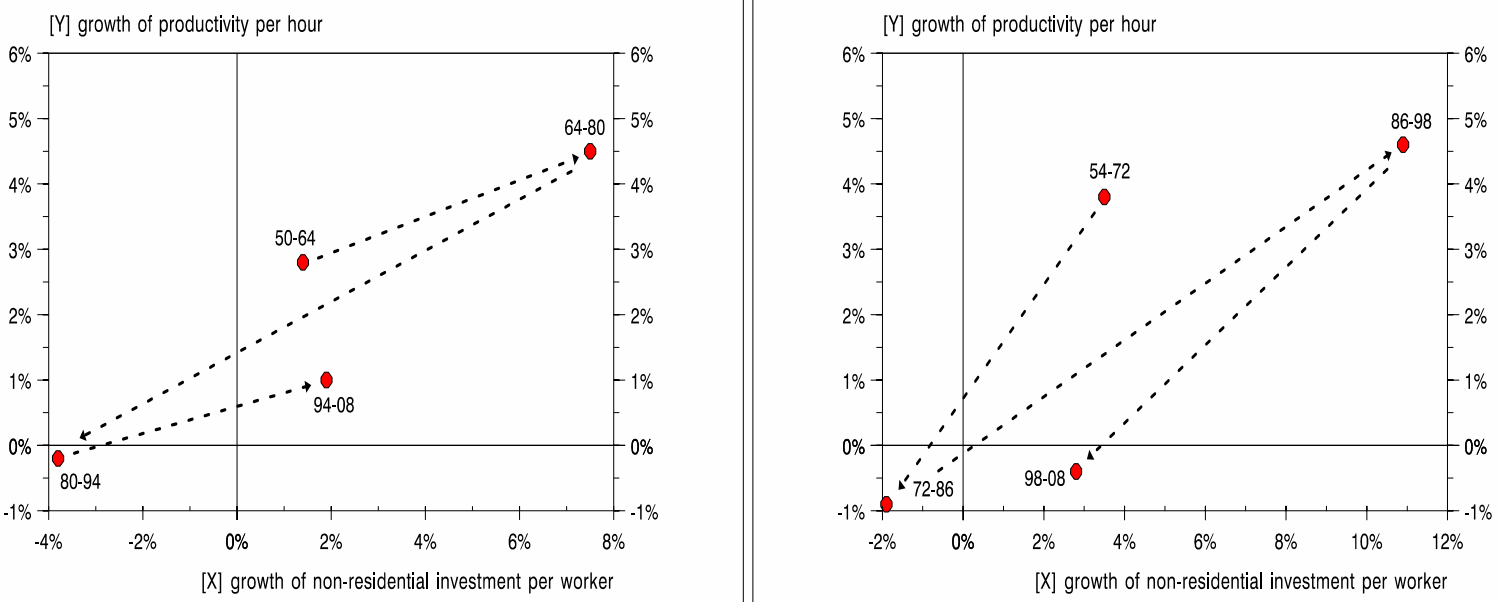

- $[\mathbf{Y}]=$ vertical axis; and $[\mathbf{X}]=$ horizontal axis. Each observation indicates the average rate of growth for both variables during the respective period.

- Sources: for productivity and employment, GGDC (2009); for investment, WDI (2010). To obtain the non-residential component of investment, I have multiplied the WDI data by the share of non-residential investment in total investment (from Hofman, 2000; this author provided the necessary updates).

Of the many intriguing issues arising from Figure 11, three are revealing: first, unsurprisingly, the periods of rapid productivity growth are associated with high investment growth. ${ }^{18}$ Second, when (for different reasons) investment declined, productivity growth did not just decline, but actually collapsed. Finally, although in both countries the growth of investment per worker in the last period resembles that in the first, productivity growth per hour worked is significantly lower (1.8 percentage points in Brazil, and 4.2 in Chile). Figure 12 shows that in this respect the striking difference between LA and Asia is even more intriguing.

18 For Kaleckian growth-dynamics, see Taylor (2010); and Ocampo, Rada and Taylor (2009). 
Latin America and Asia: growth rate of investment per worker and of labour productivity, 1950-80 and 1990-2008.

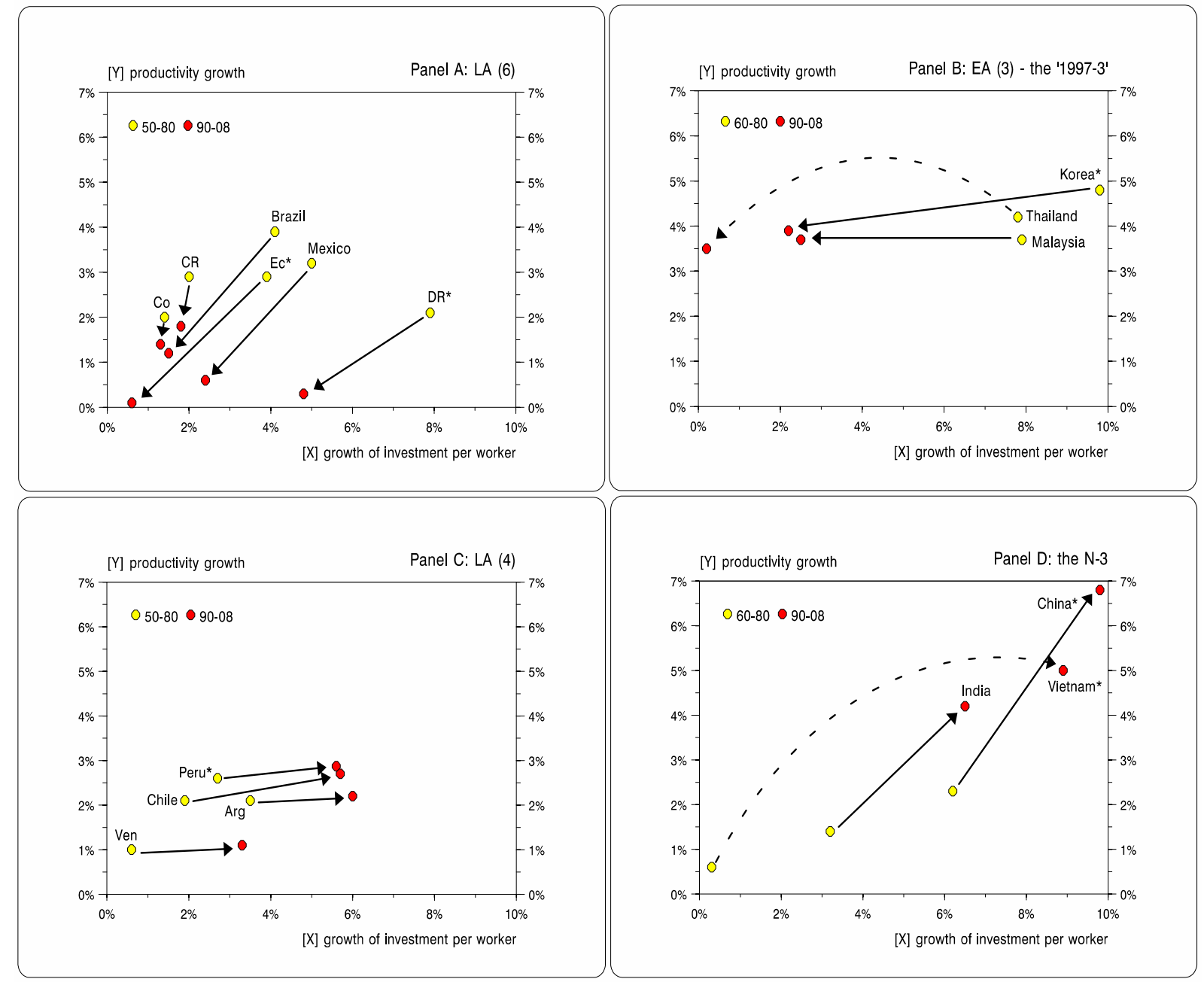

- $[\mathbf{Y}]=$ vertical axis; and $[\mathbf{X}]=$ horizontal axis. In Panels $\mathbf{A}$ and $\mathbf{C}$, due to lack of data for Ec*, DR* and Peru* first observation is restricted to 1960-80. In Panel B, Korea*, investment growth rate for $1960-80=13 \%$. In Panel D, China*, investment growth rate for $1990-2008=12.2 \%$; and Vietnam*, due to lack of appropriate data, first observation is only a rough estimate (using information from Trần Văn Thọ, et al., 2000). Note that in all panels the second period is restricted to 1990-2008 in order to compare LA's post-1990 economic reform period with its pre-1980 ISI one.

- Sources: as Figure 11 (except that due to lack of data for the residential component of Asia' investment, the horizontal axes represent the growth of overall investment per worker). Investment for Colombia, CEPAL (2010).

In Figure 12, LA is divided between those countries in which the growth-rate of investment per worker was lower in 1990-2008 than in 1950-1980 (six countries, Panel A), and those where it was higher (four, Panel C). Asia is also divided along the same lines in Panels $B$ and $D$. Starting with the top two panels, the contrast between LA (Panel A) and three of the Asian countries affected by the 1997 crisis (Panel B) could not be starker: while in LA a declining investment rate is associated with a collapse of productivity growth, in Asia an extraordinary post1997 fall in the investment rate leaves productivity growth practically unaffected. Aside from Asia's preference for absorbing shocks via employment rather than productivity, this comparison suggests a more solid productivity growth 
foundation in Asia due to higher levels and different sectoral distribution of investment. This helps to hedge productivity growth against temporary shocks in investment.

The contrast between the Latin American and Asian countries shown in Panels $C$ and $D$ is even more remarkable, indicating the opposite vertical and horizontal trajectories from those found in Panels A and B. In the four Latin countries of Panel $C$, an increased investment rate (though, in some cases, from a low starting point in 1990) is associated with constant rates of productivity growth. In the N-3 Asian countries (Panel D), meanwhile, these are instead associated with hugely improved rates of productivity growth. ${ }^{19}$

\section{4.- Latin America's unique post-reform combination of high employment elasticities and low productivity growth}

As already evident in Table 1, as far as employment elasticities are concerned, post-1980 LA seems to live in a world of its own. In fact, as already mentioned, Latin American countries' post-1980 employment elasticities are about twice as high as anybody else's - see Figure 13.

\section{FIGURE 13}

Latin America, Asia, S Africa \& OECD: gross employment elasticities, 1980-2008

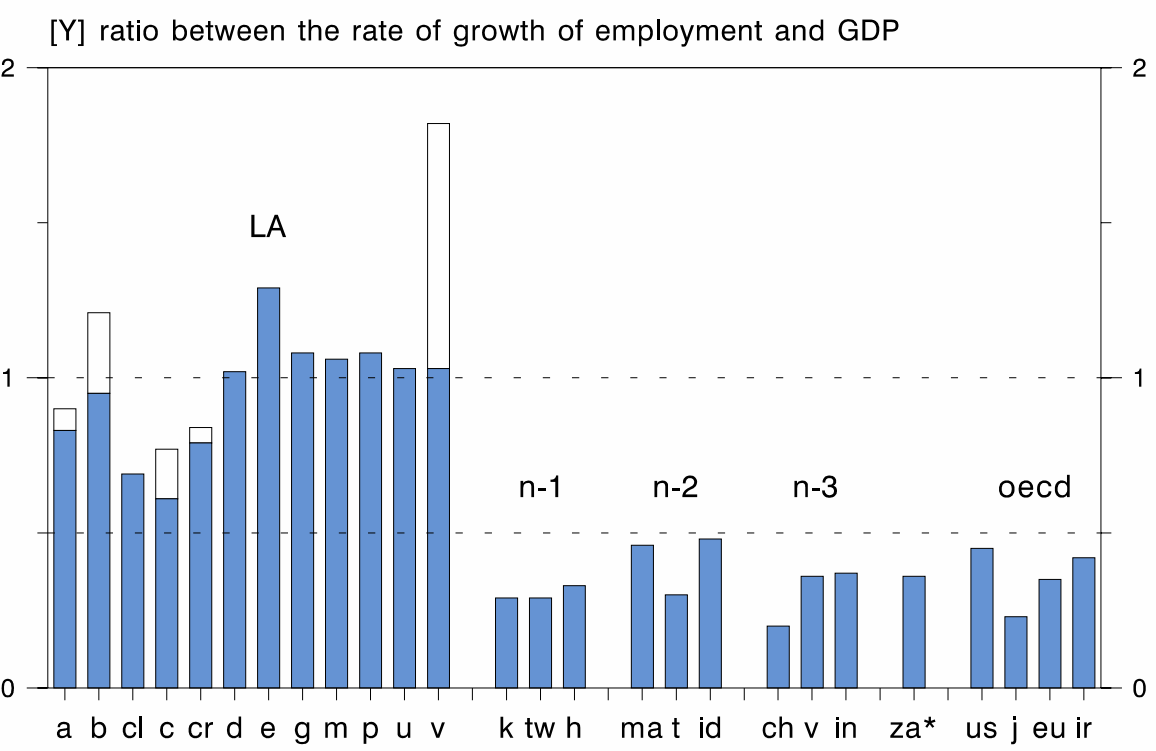

- Acronyms as in Figure 8, and (in the title) S Africa = South Africa. Also, eu = European Union; ir = Ireland; $\mathbf{h}=$ Hong Kong; $\mathbf{j}=$ Japan; $\mathbf{t}=$ Thailand; and $\mathbf{z a} *=$ South Africa between 1994-2008. Employment elasticities as in Table 1 (African countries are excluded because the GGDC, 2009 dataset does not provide data on employment, and the ILO database only provides econometric estimate; for South Africa, see Quantec, 2009). White bars on top of blue ones are additional employment elasticity when ratio is

19 In LA, Bolivia and Guatemala (not included in Panel C) do not even travel horizontally: an increased investment rate was associated with lower productivity growth. 
calculated using GDP in domestic currencies. The employment elasticities for most of Eastern Europe are actually negative (see Figure 15).

- Sources: for GDP, WDI (2010, constant 2000-US\$); for Taiwan (2010). For GDP in domestic currencies, GGDC (2007), and UN (2010). For employment GGDC (2009).

As already evident in Table 1, Latin American countries' post-1980 employment elasticities are about twice as high as anybody else's. A sectoral analysis indicates that LA's high elasticities are entirely due to services. For example, between 1980 and 2008 net-job creation in Brazil reached 32 million, of which 30 million were in services - 11 in trade/hotels/restaurants; 2 in transport/storage/ communication; 2.5 in finance/insurance/real estate; and 14 in community/ social/personal/government services. That is, while overall output in services was growing at an average rate of just $1.9 \%$, employment did so at $4.1 \%$.

Furthermore, whatever the 'populist' literature may suggest, there is no evidence that in the latter category these are mainly government jobs - in Brazil, for example, the overall employment elasticities of services reached 2.2, while excluding the latter sub-sector this increases to 3.5 (4.1\% employment-growth vs. $1.2 \%$ output-growth).

At the same time, and going against the expectations of those in the Washington Consensus, other than in the 'maquila' industry (an industry that exists mostly due to artificially-created trade restrictions in the US, which gave Mexico and some Central American countries preferential access to its markets) there is little evidence that increased employment creation relates (in a Heckscher-Ohlin-Samuelson 'market-led' fashion) to trade liberalisation. This is especially true in commodities. In fact, not only did employment in the primary sector decline in most countries (Brazil lost 2 million jobs), but also, with a few exceptions, there is no evidence that the jobs created in services are associated with the commodity boom in any significant way.

There are, of course, many political economy issues that emerge from LA's high employment elasticities, and the rôle played in it by the informal sector, that cannot be analysed here. ${ }^{20}$ However, I would like to mention at least one: the historical legacy of the 'new' left. Whatever one's views on the 'new' left, its emergence certainly helped reduce the traditional 'workers-paranoia' of the region's capitalist élites. Basically, when the 'new' left in LA became convinced that it could not get the political power to implement its own agenda, it decided to gain power to implement someone else's agenda. ${ }^{21}$ In fact, Mrs. Thatcher was right when she proudly proclaimed in one of her last interviews that 'New Labour' was her greatest political achievement. Likewise, perhaps the greatest political achievement of Pinochet (and similar military dictators) is the Latin American 'new' left. So, as far as employment was concerned, there was not much point in the region's capitalist élites continuing with their traditional anti-labour bias.

Here a comparison between Brazil and South Africa is telling. Both countries started economic reforms simultaneously, and had similar GDP-growth rates post-1994 (i.e., since the beginning of the ANC period, and the first election of Cardoso and the 'Real Plan'). However, in the following decade South Africa's GDP growth is almost entirely explained by productivity growth, Brazil's by employment. There are, of course, many differences between the two countries,

20 One is the remarkable idealisation of the informal sector by some neo-liberal aficionados, which led De Soto (1989), for example - following Milton Friedman's glowing remarks on the Italian black market - to proclaim that it was the only real 'market economy', the future of humanity!

21 See, for example, Arantes, 2007; Oliveira, 2006; and Palma 2009a. 
but the fact that in Brazil the Workers' Party (PT) became the capitalist élite's best friend (particularly after the election of Lula), while in South Africa COSATU, one of the ANC dominant forces - and despite the growing neo-liberal orientation in the ANC government's core policy-making - remained a militant organisation, had a lot to do with this. So, while Brazil increased its service employment by over one half (1994-2008), South Africa did so by only one third. From this perspective, South Africa's main problem is that it ended up with East Asian levels of employment elasticities (0.25), but Latin American levels of GDP growth $(3.6 \%)$, resulting in a quarter of its labour force unemployed.

The main lesson from the contrast between these two countries indicates that even in this globalised world there are still significant degrees of freedom regarding the labour-intensity of output. And if LA has chosen a labour-intensive growth-path and South Africa the opposite, this has been mostly for endogenous political economy reasons.

Figure 14, in turn, indicate that in LA during the post-1990 reform period there is a contrasting relationship between investment and productivity growth, on the one hand, and between investment and employment growth, on the other.

\section{FIGURE 14}

\section{Latin America: the contrasting fortunes of labour productivity and employment in the post-reform period, 1990-2008}
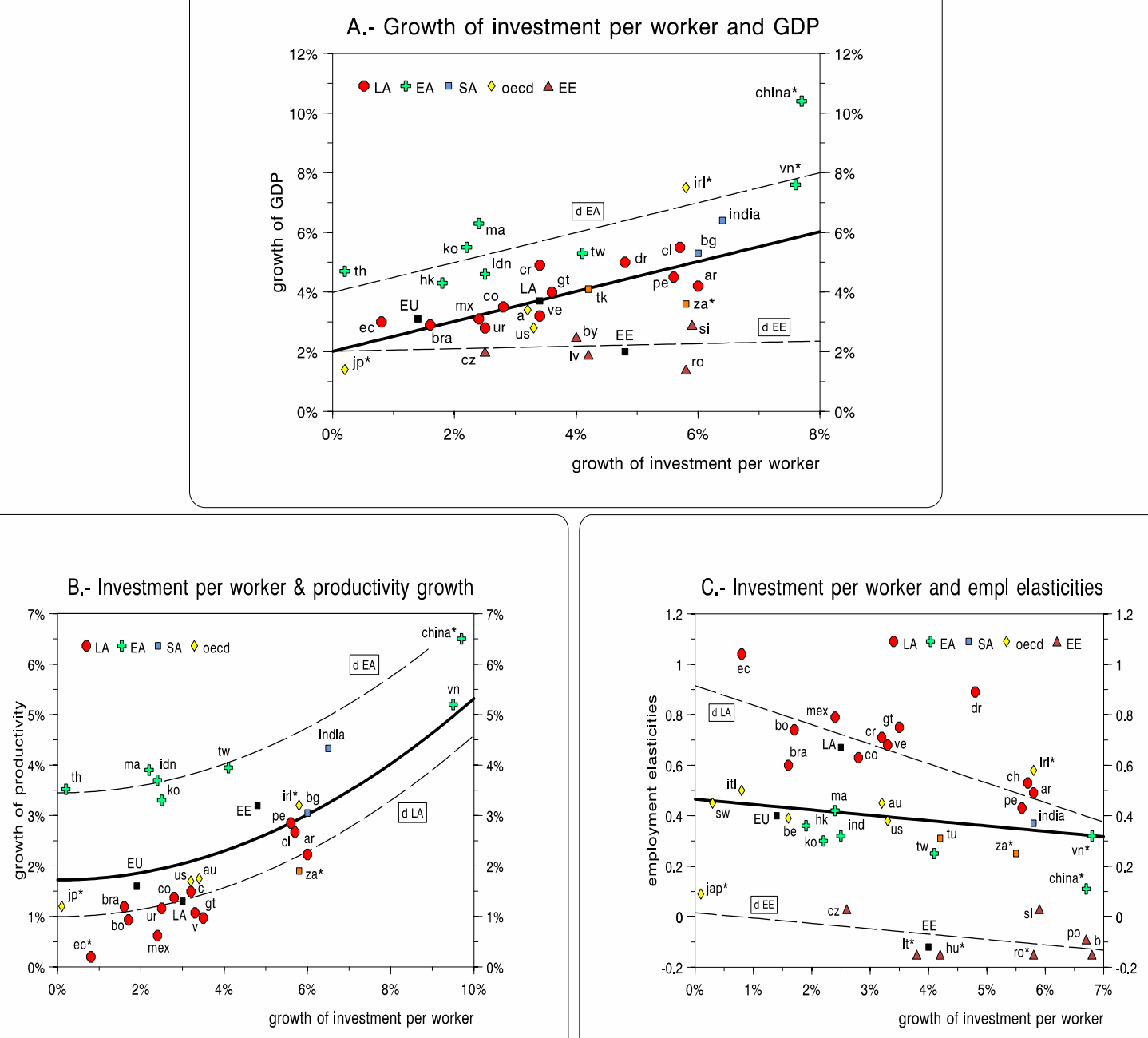
- Full titles: Panel A, Growth of investment per worker and of GDP, 1990-2008; Panel B, Growth of Investment per worker and of labour productivity, 1990-2008; and Panel C, Growth of investment per worker and employment elasticities, 1990-2008.

- Acronyms as in Figure 2, and au = Australia; bg = Bangladesh; by = Belarus; $\mathbf{c z}=$ Czech Republic; EE = Eastern Europe; hk = Hong Kong; idn = Indonesia; irl* = Ireland (1993-2007, to reflect the high growth period); Iv = Latvia; ro = Romania; si = Slovenia; tk = Turkey; tw = Taiwan; v = Venezuela; and za* = South Africa (1994-2008). china*, investment growth $=12.2 \%$; ec*, productivity growth $=-0.1$; for $\mathbf{j p} *=-0.6 \%$. 'd LA' $=$ dummies for LA (intercept in Panel C, and intercept and slop in Panel D); 'd EA' = dummy intercept for EA (Panels $A$ and $C$ ); 'd EE' = dummy slop for EE (Panel $A$ ), and intercepts for Panels $C$ and D).

- For regression statistics, see Palma (2010); $R^{2}$ in Panel $A=77 \%$; in Panel $B=86 \%$; and in Panel $\mathrm{C}=82 \%$; all variables are significant at the $1 \%$ level. In these and following regressions, ' $t$ ' statistics are calculated using White's heteroscedasticity adjusted standard errors. $^{22}$

- Sources: for GDP and investment, WDI (2010, constant 2000-US\$); for Taiwan (2010). For employment GGDC (2009).

While in panel $B$, LA is best represented by a highly significant negative (productivity) dummy, in Panel C LA generates a highly significant positive (employment) one. However, both dummies cancel each other out, and LA's relationship between investment and GDP growth (Panel $A$ ) ends up best represented by the base regression.

The fundamental point here is whether LA's ability to generate high employment elasticities may well affect investment and GDP growth negatively. More specifically, the two critical questions are: what is the nature of the relationship between LA's high employment elasticities and low productivity growth? And (crucially), if there is a fundamental relationship between the two, which is the direction of causality? See Figure 15.

22 For a discussion of the important econometric issues raised by cross-section regressions like these, see Pesaran, et. al. (2000). In particular, one has to understand that these regressions are simply a cross-sectional description of cross-country differences, categorised by the explanatory variable. That is, they should not be interpreted in a 'predicting' way, because there are a number of difficulties with a curve estimated from a single cross-section - especially regarding the homogeneity restrictions that are required to hold. 
FIGURE 15

Latin America's "flexible" labour markets, 1990-2008

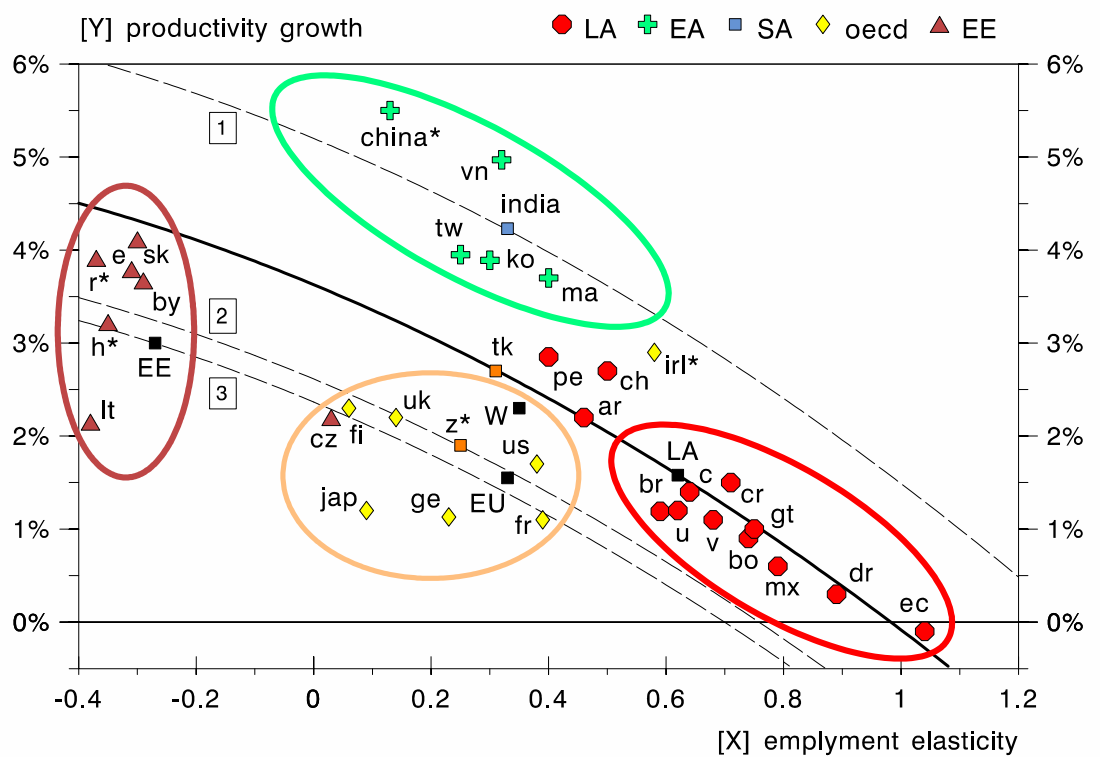

- $[\mathbf{Y}]=$ vertical axis; and $[\mathbf{X}]=$ horizontal axis. Countries and regions as Figure 2 and 12, and $\mathbf{c}=$ Colombia; $\mathbf{f i}=$ Finland; sk = Slovak Republic; uk = United Kingdom; $\mathbf{u}=$ Uruguay; and $\mathbf{v}=$ Venezuela. Employment elasticity for $\mathbf{h} *$ (Hungary) $=-1.2$; and for $\mathbf{r} *$ $($ Romania $)=-2$. china $*$, productivity growth $=8 \%$. [1] = dummy intercept for EA; [2] = dummy intercept for OECD countries; and [3] = dummy intercept for EE.

- $\mathrm{R}^{2}=85 \%$; all variables are significant at the 1\% level (Palma (2010).

Even though this is a difficult relationship to interpret as both variables (employment elasticities and productivity growth) have crucial components in common, Figure 15 complements what we already know from Figures 3 and 14 above - this time for the shorter post-reform period 1990-2008. That is, after economic reform most Latin American countries are uniquely positioned within the geography of this relationship due to their remarkable labour market 'flexibility' - flexibility in the sense that they are able to generate single-digit unemployment rates despite such poor GDP growth. Figure 15 also indicates that in the rest of the world there are also specific regional patterns.

As far as LA is concerned, there are at least two ways of understanding this intriguing relationship between employment, productivity, investment and growth. One is the (neo)structuralist view, postulating that in the absence of a binding foreign exchange constraint, output growth is largely driven by the demand. The emphasis here is on deficient effective demand leading to low GDP growth as the starting point for understanding overall low productivity growth. Sluggish output growth leads to modest labour absorption in the 'modern' (higher-productivity) sector, and to the necessity of high labour absorption in (low-productivity) services - mostly via the informal sector. The inevitable end result is low overall productivity growth (see Ocampo, 2004; and Ocampo, Rada and Taylor, 2009). So, slow aggregate productivity growth is understood mostly as a low-effective-demand/low-GDP-growth problem leading to increased 
informality, rather than as a Kaleckian-low-investment phenomenon. On such 'Pasinetti grounds', a high employment elasticity is a derived measure.

However, among other things, those working from this perspective still need to explain why is it that in other parts of the world (South Africa is just one example) low effective demand/low GDP growth leads to relatively fast productivity growth and high unemployment, rather than to LA's stagnant productivity and low unemployment (and the resulting high-employment elasticities)? Also, if their analysis is right, and in the absence of a foreign exchange constraint lack of sufficient effective demand is where the productivity problems start, in their work it is not really clear why is it that LA (but not Asia) has been saddled with sluggish effective demand since economic reform. Can it really all be due to just a fundamentalist macro?

There is an alternative perspective on the 'causality question', which is the one suggested here. Even though some of the above mechanisms may well also be at play, my view emphasises a converse logic: there are analytical and statistical reasons for arguing that the starting-point is not low GDP growth (somehow determined somewhere else in the economy), but the political economy of the labour market (reinforced by that of public finance). High employment elasticities are not the end result but the starting point of the analysis. Here the dynamics run mostly from high employment elasticities to low productivity growth via an alternative 'Cambridge-connection' - especially those of Marshall, Kalecki, Joan Robinson and Salter. In essence, I shall argue that what could be called 'excessive-labour-market-flexibility' is a key foundation for both LA's poor productivity, and low GDP growth performances - mostly via its negative impact on investment per worker, and efficiency wages. The (nonlinear) relationship of Figure 15 is also more significant when employment elasticity is the explanatory variable.

From this perspective, two different dynamics (leading to structural heterogeneity) are at work. On the one hand, in many commodities and in a few industrial and service activities openness and international competition have launched more interesting effective demand-investment-productivity growth dynamics. However, in the (more protected) bulk of the economy there is a very different reality. In LA, unemployment rates may be relatively low, but this does not mean that labour markets are tight: the labour force still grows fast by new entrants; in most countries the primary sector and often also manufacturing keep shedding labour; and there is a large 'reserve army' in the informal sector. Consequently, this dominant part of the economy (typically more than two-thirds) can operate with a remarkably elastic supply of labour and little pressure on wages, investment per worker and productivity growth. In other words, this bulk of the economy can operate with few compulsions for productivity growth thanks to 'flexible' labour markets, natural protection, and a (typically) high degree of oligopolistic concentration. ${ }^{23}$ And if in the bulk of the economy there is the option to increase output mostly by adding employment, what would be the incentive let alone the compulsion - to invest, particularly in terms of investment per worker? Moreover, as there is little upward pressure on wages what would give a Marshallian efficiency-wage dynamic a chance? As Joan Robinson analysed long ago in her criticism of the supposed 'exogeneity' of the variables making up the

23 As the head of Chile's largest holding company and former President of the Confederation of Chilean Industry explains, "in Chile [...] there are usually not more than three firms per sector. One can see this in pharmacies, supermarkets and most other activities. [...] Today we have the paradox that the world is moving towards democracy, but in Chile the movement in the economic sphere is towards the opposite direction ..." (http://www. Atinachile.cl/node/4629; my translation. See also below). 
Harrod-Domar model, the incentives for investment and productivity growth would only really kick in when the labour market gets tight.

Furthermore, as labour-intensive techniques in manufacturing have been mastered in low-income Asia - where wages are even lower and labour is in abundance - LA cannot compete in low-wage labour-intensive manufacturing anymore (except when its geographical location and US's trade treaties favour 'maquila' activities). In LA, therefore, services (both formal and informal) are the only employment-answer. At the same time (and very importantly), in relatively high middle-income countries there is also an insatiable (and often highly incomeelastic) demand for low-cost low-productivity services. ${ }^{24}$ In low-income Asia, meanwhile, more growth-enhancing labour-intensive manufacturing provides the higher employment-GDP-growth-outlet. Bangladesh is a good example of this, with its labour market more 'flexible' than India's, and an official minimum wages of less than US $\$ 2$ a day. ${ }^{25}$ So, Bangladesh follows a typical Lewis-model (2 million workers have been absorbed by the export-garment industry alone in recent years), but LA (in the bulk of the economy) follows an atypical one: there is high labour-absorption, but labour is being transferred to little or no productivity-growth-potential services - sometimes even from manufacturing (due to rapid de-industrialisation; see Palma, 2005b and Section 7 below).

LA's abysmal rates of productivity growth in services between 1980 and 2008 - either zero (Chile and Colombia) or negative (rest of the region) - are clearly not shared by the Asian countries discussed so far (India $4 \%$, Taiwan $3.7 \%$, Singapore 3.6\%, Malaysia 3.5\%, Indonesia 2.4\%, Hong Kong 2.3\%, Korea and Thailand $1 \%$ ), where (among other factors) rapid growth in manufacturing helps by pulling productivity growth in services à la Hirschman - as was often the case in LA before $1980 .{ }^{26}$ This single factor goes a long way to explaining the differences in the overall productivity growth rates between both regions.

From this perspective, one piece of the puzzle that the structuralist analysis clearly underestimates is that LA's low-productivity-growth in services is not just low effective demand/high-informality-related, but also low-investmentrelated - in particular, low-public-investment related; see Figure 16.

\footnotetext{
24 Although sometimes these activities are 'low-productivity' due to the peculiar way in which output in services is measured in national accounts.

25 After months of violent protests over poor pay and conditions, in July 2010 the official minimum wage was increased to 3,000 takas a month (US\$45), up from 1,662 takas (US\$25) - the first raise since 2006. Many international clothing companies, such as WalMart, Tesco, H\&M, Zara, Carrefour, Gap, Metro, JCPenney, Marks \& Spencer, Kohl's, Levi Strauss and Tommy Hilfiger, import in bulk from Bangladesh.

26 China's unreliable sectoral employment data makes it difficult to have a firm estimate of the rate of growth of productivity in services, but all indications are that its rate is at least as high as that of India.
} 
Latin America: growth of investment in infrastructure and in business construction per worker and productivity growth in services, 1950-2008
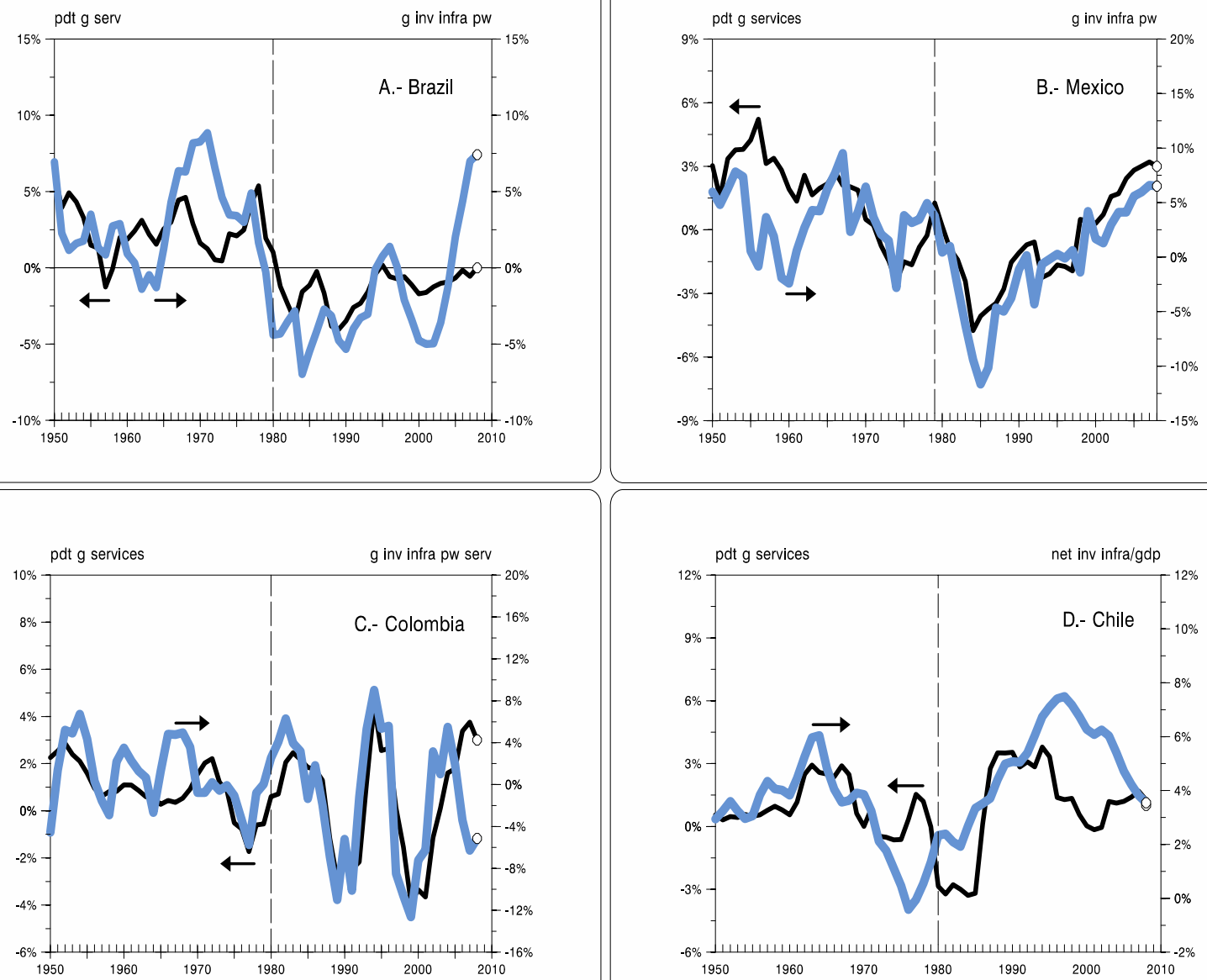

- pdt g serv = productivity growth in services; $\mathbf{g}$ inv infra pw = growth of investment in infrastructure and business construction per worker employed in services; net inv infra $=$ net investment in infrastructure and business construction as a share of GDP. Note that Chile's investment data are shown in terms of net investment in infrastructure and business construction as a share of GDP to indicate an alternative way of looking at the relationship between investment and productivity in services. Moving averages.

- Sources: investment, Hofman (2000); productivity, GGDC (2009).

An autoregressive distributed lag model confirms that in LA there is a strong correlation between the growth of investment and of productivity in services the former in terms of investment in infrastructure and business construction per worker employed in services (both series are stationary). There is also a large and highly significant investment impact-multiplier. For example, in Brazil (19602008 ), the $R^{2}$ of the regression is $50 \%$, the impact multiplier is 0.33 , and its ' $t$ ' statistics 6; and in Mexico the respective statistics are 52\%, 0.2 and $7 .{ }^{27}$

From this perspective the squeeze of public investment (particularly in infrastructure) is, of course, a crucial component of LA's post-1980 abysmal rates of productivity growth in services. Chile's 1986-1998 investment boom in

27 For similar statistics of this regressions for other countries, see Palma (2010a). 
infrastructure and business construction is the exception that confirms that in LA, too, services can not only absorb labour (3.8\% per annum during these 12 years), but can also have an East Asian rate of productivity growth (3.3\%; see also Figure 17$).^{28}$

In sum, low productivity growth in services (and, given the huge size of this sector, in the overall economy) is not just a low-effective-demand/low-GDPgrowth phenomenon limiting the capacity of the 'modern' sector to absorb additional labour (with 'high-employment-absorption-informality' coming to the rescue, like the cavalry in every good old Western - the structuralist model). It is also the result of both the political economy of LA's labour markets, and (a mostly public-investment-squeeze-related) low investment in services endogenising sluggish output growth. ${ }^{29}$ The resulting productivity growth rates may be poor, but there is a relatively stable low-intensity dynamic that the 'invisible hand' finds it difficult to break. ${ }^{30}$ This, together with peculiar politics (particularly when the 'new' left is involved), has led to political settlements characterised by 'low-intensity' Nash equilibria (Palma, 2009c; see also below). And where something different has been attempted, as in Venezuela, the results have been rather disastrous.

So, in most of the region today investment per worker is below, or at best similar to 30 years ago, and the unintended consequence of tight monetary policy (making sure that labour markets never even begin to get tight) is to preserve this 'market failure'. Unless governments get serious in achieving East Asian levels of public investment, and in implementing East Asian-style trade and industrial policies, more growth-enhancing macros, more effective market compulsions and other forms of 'disciplining' the capitalist élite, it is difficult to envisage a breakthrough. Unique specific circumstances may have helped some countries to break temporarily with this dynamic (like the rather unusual transition to democracy in Chile), but perhaps it is unsurprising that after a relatively short period they have returned to the fold, their burst of productivity growth having fizzled out. In the case of Brazil, for example, and despite the current growing euphoria (and what Ortega y Gasset would have probably called an abundance of "self-satisfied individuals"), there is so far little concrete evidence that Brazil's current (and well-publicised) growth-acceleration could prove to be the exception to this rule. ${ }^{31}$

28 In the post-1973 economic reform period in Chile there has been no productivity growth in services either before or after the 1986-1998 period of high investment in infrastructure and business construction. In the preceding period (1973-1986), productivity growth in services averaged $-1.8 \%$ per annum; and in the period that followed (1998-2007), this averaged $-0.1 \%$.

29 In net-terms, in most of LA investment in infrastructure and business construction was remarkably poor (sometimes even negative), not just during the 1980s, but also after reforms; see Hofman (2000).

30 Nelson was already trying to address this issue of 'low level equilibrium traps' in the 1950s (Nelson, 1956).

31 Recently released GDP data for Brazil has further contributed to the current euphoria, as they were 'better than expected'. However, mixed with the good news there were already indications that the three main economic problems of Brazil continued unabated: investment was already loosing momentum; imports were growing significantly faster than exports; and manufacturing continued to fall behind other activities — in fact, as a share of GDP, in 2010 manufacturing had the lowest share since the end of the Second World War (15.7\%; a share only similar to that of the crisis year of 1998 , and one that was less than half the level of the late 1970s and 1980s. See 'indústria de transformação: valor adicionado a preços básicos', in http://www.ipeadata.gov.br/). But at times of economic jubilation, minor 'inconveniences' like these don't really take the sparkle out of the congratulatory champagne... 
Within the context of the above-mentioned structural heterogeneity, LA has developed two types of successful 'modern-sector' regional oligopolies: those involved in large-scale capital-intensive commodity production for exports, and those that have mastered the technique of organising low-value-added labourintensive production chains - sometimes for exports (mostly agricultural products), and sometimes in services (eg. retail). ${ }^{32}$

Ultimately, in LA, the commodity boom (helped by favourable prices) has lifted foreign exchange constraints; services have generated the precarious, lowproductivity and low-wage employment (both formal and informal); while financial markets have provided all the fun. ${ }^{33}$

So, what is really wrong in post-reform LA is that neither the really 'modern' sector (usually associated with large-scale commodity production, although in Mexico also with its non-maquila manufacturing exports, and in Brazil with many of its 'BNDES-encouraged' manufacturing), nor the rest of the formal economy (mostly oriented towards the domestic market, although lately more regionally oriented), or (unsurprisingly) the informal sector are able to generate much of what really matters for the complexities of economic growth - i.e., the externalities and the spill-over effects that may help set in motion processes of cumulative causation that take advantage of dynamic economies of scale, increasing returns, etc. ${ }^{34}$ That is, those issues which are central to the 'how-onething-leads-to-another' Hirschmanian growth-philosophy when dealing with such intricate market structures as those that characterise developing countries complexities that get even more intricate as developing countries move to middle and high-middle income levels.

Although neo-liberals were just about the only political group who really understood Kalecki's hypothesis that capitalism cannot endure the political consequences of sustained periods of full employment, Latin American neoliberals have overshot in the opposite direction: capitalism with clearly insufficient labour market compulsions seems not to work very effectively either. That is, as capitalists practically need not compete with each other in the labour market, there are few market pressures coming from this direction either forcing productivity growth, or the investment levels necessary to back this up.

To perpetuate this, in most countries there is no collective bargaining, strikebreakers are legal, and sub-contracting labour (as a mechanism to bypass even timid labour legislation) is widespread - even in the public sector. At the same time, minimum wages are set at remarkably low levels (in Mexico, for example, in 2010 the value of the minimum wage was worth just one-third of its 1976 level). ${ }^{35}$ And there are still activities in which workers do not even have a

32 Their success has made the entry by foreign firms into the latter markets difficult; it is only when these regional oligopolies need new technologies that they get a foreign partner (rather than making the creative effort themselves) - see Robinson (2008).

33 In LA (2002-2007) the capitalization of the stock exchanges increased annually by 45 percent in real terms, bank assets by 21 percent, and private and public bonds by 22 percent and 25 percent (see IMF, 2009 ).

34 These are the kind of (difficult-to-model) issues that were usually ignored by traditional (constant-returns-cum-perfect-competition) mainstream economics, and are now tackled (but so far not very successfully) by the 'new' traditions in mainstream thought. In 'newgrowth' theory, for example, growth is now normally modelled as a function of market imperfections that somehow create increasing returns in the process of technical changebut this process is still explicitly modelled as not-sector-specific (see, for example, Aghion and Howitt, 1998; for a critique, see Palma, 2005b).

35 This is the value when its nominal level is deflated by the index of consumer prices; see http://www.inegi.org.mx. See also Palma (2005b). Latin American neo-liberals have not paid much attention to Churchill's views that low wages only subsidise inefficient 
legal minimum wage, or some other basic right - domestic servants in Chile, for example, an occupation that accounts for $12 \%$ of female employment, still do not have a minimum wage, and their legal working hours are 12 per day. ${ }^{36}$

Moreover, in those activities where minimum wages do apply, they are often ignored; and even in the formal sector many workers do not have a labour contract. ${ }^{37}$ And so on. Also, at the first sign of labour markets getting tight, not just 'independent' Central Banks, but also governments are quick to react. In Chile, for example, in the early 2000s when the market for domestic servants became slightly tight, and meagre wages began to increase, the government (presided over by a member of the Socialist Party) immediately opened up immigration from Peru - many things are possible in LA, but middle classes unable to afford domestic servants is not one of them.

\section{5.- Sectoral diversities and the "one-thing-at-a-time" process of catching-up}

Figure 17 measures the relative productivity gaps of four Latin American countries vis-à-vis the US. In Panel A, Brazil's productivity gaps throughout the whole 1950-2007 period show very clearly LA's 'one-thing-at-a-time' style of catching-up. While pre-1980 ISI succeeded in significantly closing the manufacturing productivity gap, this happened at the expense of commodities; the opposite was the case afterwards. One big difference, however, is that (as in EA) the pre-1980 manufacturing catching-up also managed to pull services à-laHirschman. This goes a long way to explaining the differences in the aggregate productivity growth rates between the two periods (2.6\% per annum for 1950 1980 and $0.2 \%$ for $1980-2008$ ). Another one, of course, is the superior growthenhancing characteristic of manufacturing due to its dynamic economies of scale, spill-over effects, and so on. And yet another is the fact that the post-1980 commodities' catching-up (except in Chile) was really only a narrow mining phenomenon.

producers. For example, in his speech to the House of Commons proposing the legislation to create 'Trade Boards' to regulate workers' remuneration in industries with low wages (28 April 1909), he explained that the Boards were necessary in industries where the bargaining strength of employers greatly outweighed that of workers. According to him, "... where you have what we call sweated trades, you have no organisation, no parity of bargaining, the good employer is undercut by the bad, and the bad employer is undercut by the worst." For an analysis of the minimum wage in Britain, see http://www.iatge.de/ aktuell/veroeff/2005/gr2005-01.pdf.

36 According to the main household survey, in 2006 their average working week actually reached 75 hours; see http://www.mideplan.cl/casen/.

37 In Chile, in 2000, half of the workers in non-agricultural firms that earned the minimum wage or less did not have a labour contract; see Infante, Marinakis and Velasco, (2003). 
Brazil, Mexico, Colombia and Chile: relative productivity gaps with the US
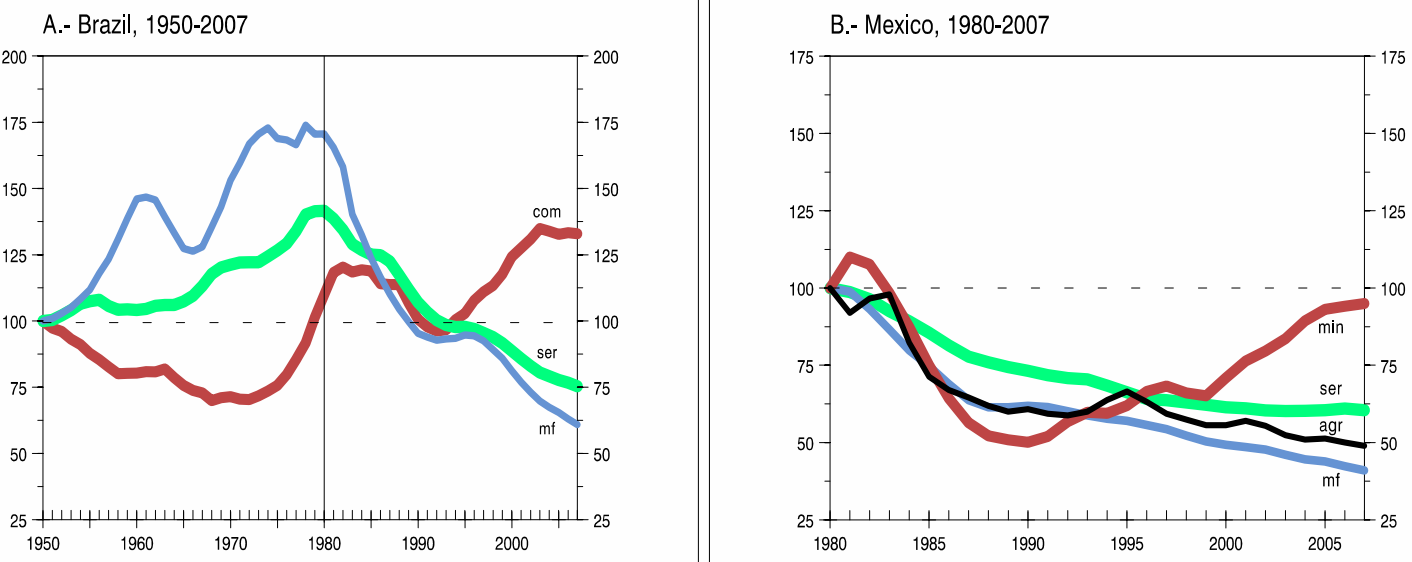

\section{C.- Argentina}

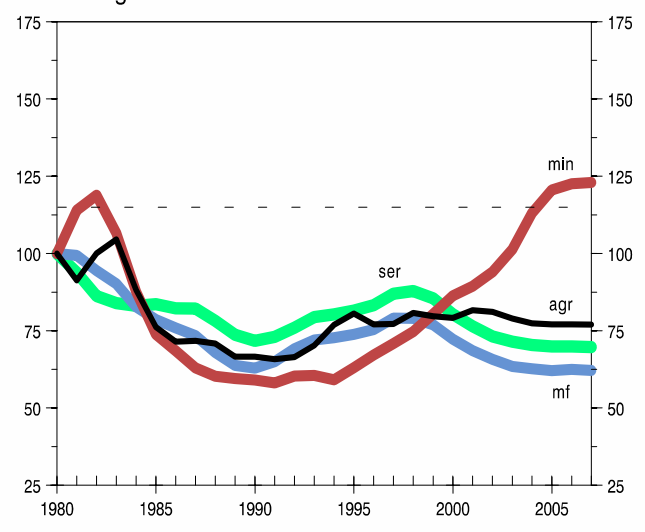

D.- Chile, $1980-2007$

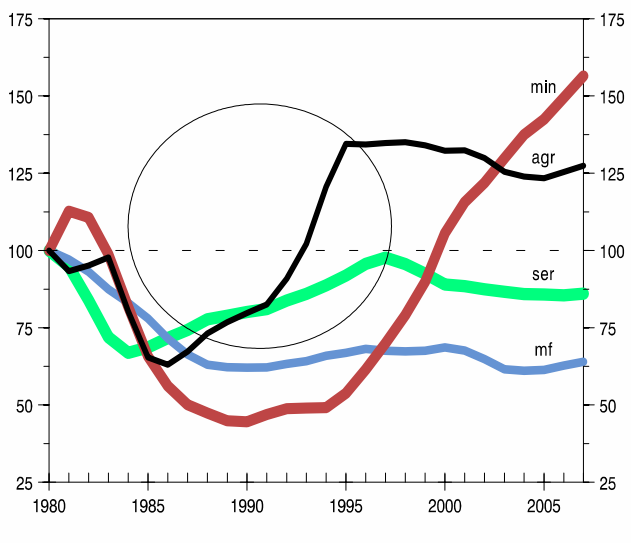

- $\mathbf{c o m}=$ commodities $($ primary sector) $;$ agr = agriculture, forestry and fishing; $\mathbf{m i n}=$ mining and quarrying; $\mathbf{m f}=$ manufacturing; and serv = services.

- Each line is an index number (1950 = 100 for Brazil, $1980=100$ for the rest) of the ratio of labour productivities between the respective country and the US (each in real terms and domestic currencies). An increase implies 'catching up' with the respective labour productivity in the US, and a decline a falling behind. 3-year moving averages.

- Source: GGDC (2007); UN (2010); and ILO (2010).

This does not mean that agriculture had not also gone through a major transformation as well. In fact, a technological revolution has been unfolding, which has altered the organization of production and the social relations in the rural sector of several Latin American countries (see, for example, Katz, 2004). In many cases, 'sowing pools' and 'cero tillage' production arrangements have replaced the traditional farmer. And this technological and organizational change has not come about only because of the influence of multinationals; it has also been the result of domestic technological efforts involving R\&D carried out both by public institutes (such as Fiocruz or Embrapa in Brazil, INTA and Instituto Malbran in Argentina, INIA in Chile), and local companies. However, as these transformations in agriculture has also taken place in the US, even in Argentina (and despite the remarkable boom in soya) the overall agriculture productivity gap with the US widened vis-à-vis 1980. The same happened in Brazil. 
The primary commodities revitalization has also had the added advantage of benefiting from the post 9/11 surge in commodity prices. Yet, as this phenomenon has been fuelled by massive speculation, it may well prove to be no more than a short term bubble; although it is possible that it could last for longer, while China and India continue to surge ahead, and (over-liquid) financial markets continue to be attracted by commodities. However, the key question here, as well as with the mining, timber and fisheries' revolution is why they have had such little capacity to pull the rest of the economy with them. Basically, what is happening is that while a few activities in the primary sector have succeed in forging ahead in their efforts to 'catch-up' with their counterparts in rich nations, the bulk of the economy (including, as Figure 17 shows, most of manufacturing) is being left behind. "Convergence", therefore, seems to be a far more complex phenomenon than it is implicit in neo-classical models. This is a remarkable fact that (with few exceptions; see Katz, 2004) finds little emphasis in the literature.

Panel D synthesises Chile's better 1986-1998 GDP performance. What took place was mostly an investment-led burst of productivity growth in agriculture, forestry and fishing (10\% p.a.), and increased productivity in services (3.3\%, backed up by infrastructural investment and business construction; see Figure 16 above). The growth of productivity in mining only started in the mid1990 s (when other sectors began to falter), reaching $11 \%$ p.a. in 1994-2003. In addition, after falling behind in the 1980s, the productivity gap in manufacturing stabilised (although, in part, this was due to a particularly rapid rate of deindustrialisation in Chile; see below).

One phenomenon apparent from Panel B is Mexico's particularly poor performance. For reasons of space, I cannot analyse this here in detail (see Palma, 2005a) but, basically, an economy with FDI levels and access to the US markets that policy-makers in other developing countries can only (day)dream of, has performed particularly disappointingly in terms of productivity growth falling behind the US in all sectors.

Regarding the remarkable neglect of manufacturing, as argued elsewhere (Palma, 2005b, and 2008; see also Section 7 below), there is plenty of evidence to suggest that the closer one gets to the productivity frontier, the need for industrial policy increases exponentially. From this perspective, the sad irony is that LA abandoned industrial policy at the very moment it needed it most! ${ }^{38}$ So, for example, since 1980 manufacturing productivity in the US has forged ahead of Brazil's by a factor of 3.5 (Panel A); by a factor of 2.3 vis-à-vis Mexico's (Panel $B$ ); by a factor of 1.7 vis-à-vis Argentina's (Panel C); by a factor of 1.6 vis-à-vis Chile's (Panel D); and by one of 2.4 vis-à-vis Colombia's (not included in Figure 17). Moreover, as most of Asia was catching up with the US in manufacturing, LA was falling behind Asia by an even larger relative margin (see Figure 18).

38 See also, Khan and Blankenburg (2009). 


\section{Brazil, Mexico, Argentina and Chile: relative productivity gaps with four Asian countries}

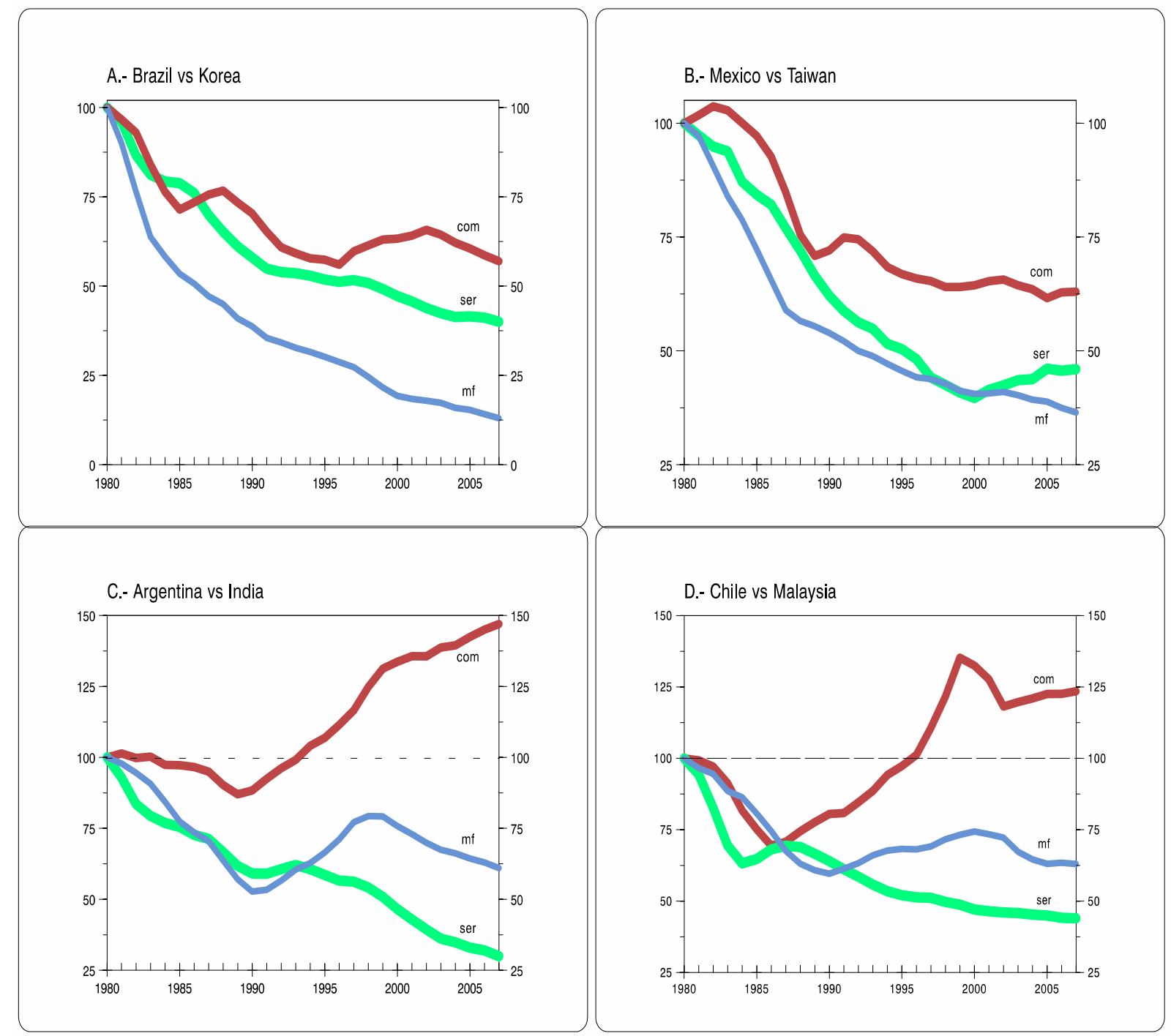

- As Figure 17.

The collapse of Brazil's productivity in manufacturing relative to Korea's is truly remarkable: since 1980, manufacturing productivity in Korea has forged ahead of Brazil's by a factor of 7.5 (Panel A). In turn, Mexico fell behind Taiwan by a factor of 2.8 (Panel B); Argentina vis-à-vis India (in a cyclical fashion) by a factor of 1.6, and in services by one of 3.4 (Panel C); and Chile vis-à-vis Malaysia (during the 1980s) by a factor of 1.6, and in services by one of 2.4 (Panel D).

At the beginning of September, The Economist joined the prevailing regional economic euphoria - based exclusively on the fact that after a soft landing from the global financial crisis, a few countries of the region are experiencing an acceleration of their growth rate led entirely by commodities, finance and real estate - and predicted that what is coming may well be a "Latin American decade", with Brazil as its powerhouse. And who knows? The 2010s might indeed surprise the sceptics and end up as the Latin American decade (in fact, more implausible events have occurred before), but so far the hard evidence is clearly on the side of yet another 'Asian decade'. 


\section{6.- Exports as a faltering engine of growth: the 'middle-income export-trap'}

As far as exports are concerned, LA moved from a situation in which pre-1980 exports and GDP were growing at roughly the same pace $(5.2 \%$ and $5.7 \%$ per annum between 1960 and 1980, respectively), to one where exports grew nearly three times faster (7.1\% and $2.6 \%)$ - even more in Mexico $(8.8 \%$ and $2.6 \%$; WDI, 2010, data in constant 2000-US\$). As in the ISI period income elasticities for imports were certainly higher than one, there was an inevitable foreign exchange constraint on growth (and a resulting accumulation of foreign debt); therefore, a pro-exports policy re-engineering was surely inevitable. However, the one chosen has not been the most effective: while the rate of growth of exports has increased on average by half, that of GDP fell by about half $(8.1 \%$ and $3.4 \%$ for the post-1990 economic reform period, respectively - even more disproportional in Mexico, $9.8 \%$ and $3 \%$; Ibid). ${ }^{39}$ In this pro-exports policy reengineering, the East Asian strategy of simultaneously insulating domestic markets and outwardly orienting manufacturing production was never even considered as an option.

So, unsurprisingly, when comparing LA with the rest of the world the region generates a significant negative export-GDP dummy (highly influenced by the disappointing performance of Brazil and Mexico; see Figure 19).

\section{FIGURE 19}

Export and GDP growth in four developing regions, 1990-2008

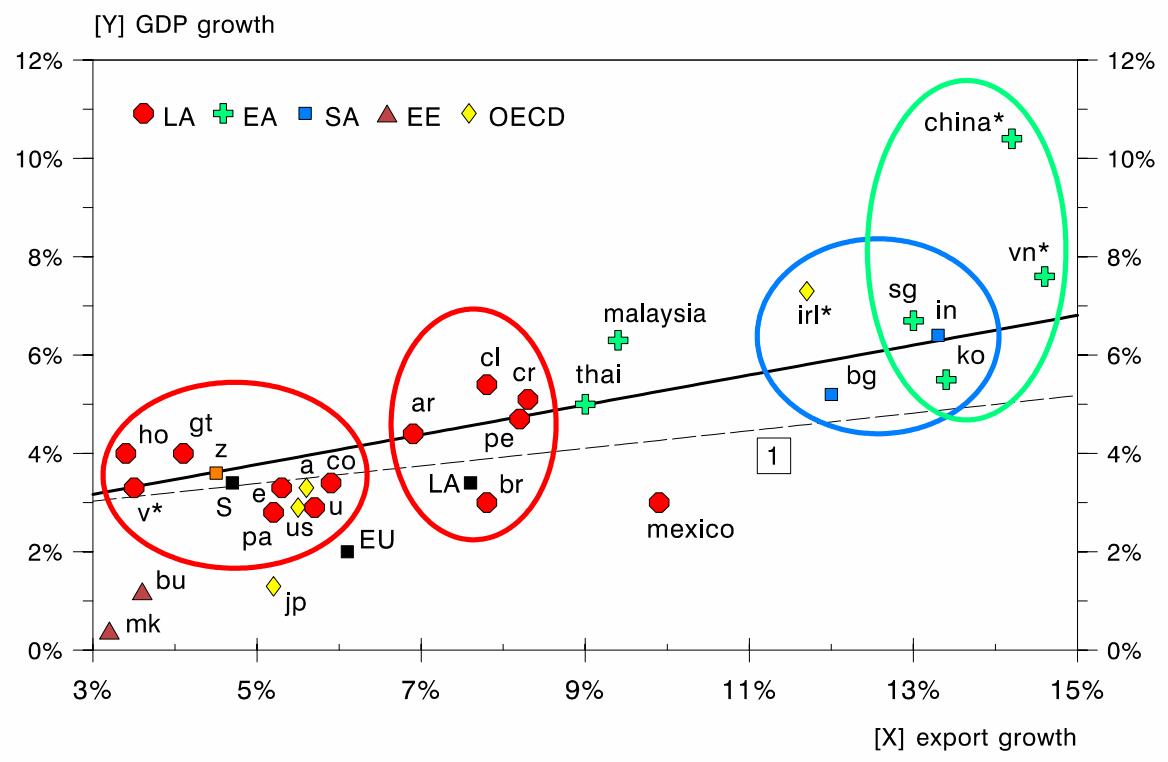

- $[\mathbf{Y}]=$ vertical axis; and $[\mathbf{X}]=$ horizontal axis. As Figure 2 and 11 , and $\mathbf{a}=$ Australia; bu = Bulgaria; china*, export growth = 17.1\%; e = Ecuador; It = Lithuania; $\mathbf{m k}=$ Macedonia; $\mathbf{S}=$ Sub-Saharan Africa excluding South Africa; $\mathbf{*} *=$ Venezuela (exports growth $=0.2 \%$; $\mathbf{v n} *=$ Vietnam (exports growth $=19.8 \%)$; and $\mathbf{z}=$ South Africa (1994-

39 These averages exclude the special case of oil-rich and politically distinctive Venezuela; if included, the regional averages are $6.8 \%$ and $3.4 \%$, respectively. 
2008). [1] = negative intercept dummy for LA; there are also a negative intercept dummy for the OECD and for the EE (not included in Figure). LA's average excludes Venezuela.

- $\mathrm{R}^{2}=79 \%$, and all variables (including dummies) are significant at the $1 \%$ level (Palma, 2010).

- Source: WDI (2010).

There is little doubt that one of the foundations of LA's negative export-GDPdummy is the fact that in an export-led model what matters is not only how much, but what one exports - and, of course, how does one make those exports (i.e., the question of the value added content of exports - in the Latin American context, this refers especially to the 'maquila' issue). In addition, having a nonmonetarist growth-enhancing macro-policy (able to deliver both a competitive exchange rate and a sensible and stable interest rate, as in most of fast-growing Asia) also helps. The comparison between Mexico and Malaysia (or Thailand) is the most telling (see middle of the graph).

Figure 19 also indicates that in this relationship there are two different clusters in LA, with the more dynamic export group composed of Argentina, Chile, Costa Rica and Peru (followed by Brazil and Mexico, with dynamic exports but sluggish GDP growth). Also, with the exception of the latter two countries, this small, livelier group is best represented by the base relationship (rather than the Latin American negative dummy). Figure 20 looks at the 'quality' of exports issue.

FIGURE 20

'Anti-clockwise' export-trajectories between the 1960s and the 1990s

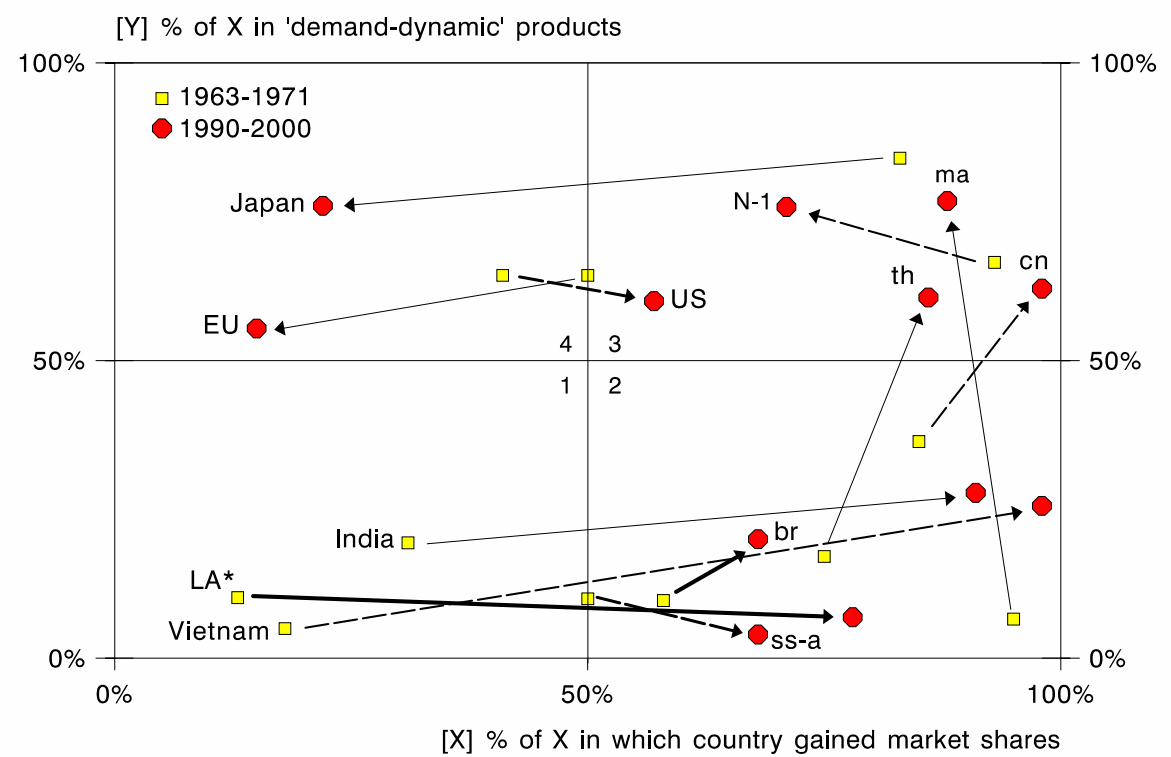

- $[\mathbf{Y}]$ = vertical axis = percentage of exports in products that were 'demand-dynamic' in OECD imports (i.e., products that increased their share in OECD imports during respective periods due, for example, to their higher income elasticity); and $[\mathbf{X}]=$ horizontal axis = percentage of exports in which the respective country or region gained market shares in OECD imports during the relevant period. That is, the vertical axis refers to product 'quality', and the horizontal one to countries/regions' 'competitiveness'. Excludes oil. LA* 
= Argentina, Bolivia, Chile, Colombia, Ecuador, Paraguay, Peru and Uruguay (i.e., Latin America excluding Brazil, oil-exporting Venezuela, and Mexico and Central America due to maquila exports); $\mathbf{N - 1}$ excludes Hong Kong. Data for Taiwan correspond to those reported in the second edition of the Trade-CAN software. Regarding Vietnam, the first observation corresponds to the period 1973-1984 (i.e., from the date when US combat troops left Vietnam until the beginning of economic reform; Trần Văn Thọ, et al. 2000).

- First observation: export profile of a country or region between 1963 and 1971 . Second observation: that between 1990 and 2000. If an observation is in Quadrant 1 this indicates an 'uncompetitive' country (i.e., less than half its exports have gained market shares) exporting 'non-demand-dynamic' products (i.e., less than half its exports are 'demand-dynamic' products); if it is in quadrant 2, it shows a 'competitive' country exporting 'non-demand-dynamic' products; if in quadrant 3, a 'competitive' country exporting 'demand-dynamic' products; and in quadrant 4, an 'uncompetitive' country exporting 'demand-dynamic' products - see Appendix 3 in Palma (2009) for a more formal definition of the four quadrants.

- Source: Trade-CAN (2009).

This Figure shows that LA's remarkable improvement in market shares in world trade (i.e., increased export-competitiveness) - the successful movement from quadrants 1 to 2 - was not accompanied by an improvement in the 'quality' of its exports (an upward movement from ' 2 to $3^{\prime}$ ). ${ }^{40}$ It is well known that LA's improved export-competitiveness did not include many 'high-tech' products, with their high-positive-externalities and spill-over-effects (see Palma, 2009b). Figure 20 indicates that it did not include demand-dynamic products in general. Meanwhile in EA the swift movement of the $\mathrm{N}-2$ countries and China from quadrants 2 to 3 is so fast that it even eats away some degree of exportcompetitiveness of the $\mathrm{N}-1$. This process is much more acute vis-à-vis Japan (and the EU). With the exception of the US (mostly due to the Clinton years), the overall pattern that emerges is an anti-clockwise trajectory.

For LA and other countries moving into quadrant 2, the crucial strategic trade and industrial policy issue is whether there are endogenous market forces that would lead them afterwards in an upward '2-to-3' trajectory. Or whether there are crucial (Ricardian) market failures that would (at best) trap them into being increasingly competitive in products that tend to be marginalised (in value terms) from world markets - except for temporary cycles such as those benefiting many commodities after 9/11, and after the 2008 global financial crisis. Furthermore, especially in commodity-markets, excessive competitive struggle for market shares often leads to a self-defeating fallacy of composition problems.

So far, there is little evidence of endogenous upward forces from '2-to-3'. Countries in quadrant 2 seem to need an East Asian-style 'exogenous push'. For these policies to be effective, however, what is also needed is an underlying power structure and institutional arrangements that would allow them to be successful (as was the case in most of Asia). These include a professional bureaucracy capable of devising a competent educational and training system that encourages the acquisition of productive capability, ${ }^{41}$ as well as able to implement intelligent trade and industrial policies that generate rents as incentives for the transfer of resources towards more growth-enhancing activities

40 In Palma (2009b), I show that the statistic used in Figure 20 to measure 'demanddynamics' could also be considered a proxy for a product's technological content.

41 In terms of education, LA tends to score well on quantities indicators (such as enrolment, gender, etc.), but rather badly in terms of quality. For a recent study of the weakness of the Chilean educational system, see Carnoy, at www.stanford.edu/dept/ SUSE/ICE/pdfs/Chilepaper.pdf, and Waissbluth (2010). 
(such as those with more long-term productivity growth potentials); and a state strong enough to be capable of imposing performance-related conditionalities to 'discipline' the capitalist élite to use these rents effectively. That is, a state capable of threatening non-performing companies credibly with withdrawal of subsidies.

If these policies - and the institutional arrangements necessary for their success - are not implemented in LA, the potential GDP-growth-enhancing effect of further increases in export-competitiveness would continue to be restricted by the generally low productivity growth long-term potential of its current export pattern, its modest positive externalities and spill-over effects, and (crucially) its low capacity to induce productivity growth elsewhere in the economy (including services). ${ }^{42}$ In other words, as has become evident so far, without these policies LA's current export pattern has little capacity to generate growth-sustaining processes of cumulative causation. Furthermore, lack of an upward movement from ' 2 -to-3' could seriously affect the welfare gains from trade specialization in terms of the purchasing power of exports.

Existing evidence for LA indicates that the (not-so-)invisible hand of globalised markets are only creating incentives leading towards further penetration into quadrant 2 . This 'quadrant-2 stickiness' is what I like to call the middle-income 'exporter trap.' This 'trap' seems to be equally relevant to those who export commodities (in terms of their capacity to increase the share of manufacturing value added in their exports, via the up and downstream manufacturing activities associated with commodity extraction and processing, as in the 'Nordic model'), as to those who export 'maquila-manufacturing' (in terms of their capacity to augment the share of value added in the gross value of output, especially via an increased domestic production of inputs). ${ }^{43}$ In fact, current Ricardian international comparative advantages, as Cimoli, Dosi and Stiglitz (2010) state, "are a luxury that only technological and market leaders can afford (indeed a major asset that they can exploit)". One case in point is Chile, whose Ricardian comparative advantages led to a horizontal export trajectory (in fact, slightly downward) from quadrant 1 to 2 . Its copper industry is a good example; while rapidly gaining market share, Chile has actually been reducing the share of manufacturing value-added in its copper exports, with the proportion of refined copper in total exports being drastically reduced in favour of the far more primitive copper 'concentrates' (Palma, 2009b). ${ }^{44}$ Not much evidence of a Hamilton-List-Akamatsu-style logic here. There is ample evidence, however, that the sharp slowdown in Chile's growth since the late 1990s is partly due to this under-investment in upward productive diversification (Moguillansky, 1999). Finally, the nature of regional trade agreements with the US is likely to make the

42 On the distinction between "allocative", "Schumpeterian" and "growth" efficiencies, see Dosi, Pavitt and Soete (1990), and Cimoli, Dosi, Nelson and Stiglitz (2009).

43 Unfortunately, as exports are only measured in terms of gross value of output, the lack of 'deepening' of maquila exports cannot be shown in Figure 20. In Mexico, for example, the share of imported inputs in the gross value of production by maquila-export activities has remained constant at about $75 \%$ of the total. In fact, in this 'end-of-value-chainassembly-activities' the gross value added is not only a small proportion of the value of exports, but its relative size has actually declined (see http://www.inegi.org.mx; and Palma (2005a).

44 In Chile, the proportion of refined and 'blister' copper (i.e., copper that is 96 to 99 percent pure) has fallen from $97 \%$ of total copper exports in 1972 (i.e., before economic reforms) to about $60 \%$ in the mid-2000s - in favour of the far less processed form of copper 'concentrates' (with just over one third metal content). See, http://www.cochilco. cl/english/productos/anuario.asp; Caputo (2000); Lagos (2000); and Debrott (2001). 
'2-to-3' transition even more intricate - as opposed to Asia's Japanese and Chinese 'upward pulling' powers. ${ }^{45}$

In sum, export-led growth when based on relatively unprocessed primary commodities or 'thin' maquila exports has proved to be a poor engine of growth. The main lesson from post-reform LA is that if the region wants to insist on this export orientation, it should think about this model only as an export-'enabling' growth-strategy, not as an export-'led' one. That is, one in which dynamic (but not much growth-enhancing) exports can only be expected to provide the necessary foreign exchange to enable a fast rate of growth that is not balance-ofpayments constrained. However, for this growth actually to take place there is still the need for a proper 'engine' to be found elsewhere in the economy. That is, other sectors or activities that would play the role of 'production frontier shifters', able to set in motion processes of cumulative causation - characterized by their positive feedback loops into the system, and capable of generating a momentum of change which is self-perpetuating (e.g., in the Veblen/Myrdal or the Smith/Young/Kaldor manner). There is not much evidence from LA that unprocessed primary commodities or 'maquila' exports can play that role - nor that the countries of this region have made much effort toward export-upgrading or looking elsewhere for an effective engine of growth; furthermore, their 'monetarist' macro and open capital accounts have contributed to a deficient effective demand by switching a disproportionate amount of the aggregate demand towards foreign markets due to overvalued exchange rates.

As Stiglitz always insists, even from the narrow perspective of mainstream economics, in a world full of distortions the lifting of one (e.g., a trade barrier or a capital control) does not necessarily lead to a superior (let alone optimal) equilibrium. Or, as Lipsey and Lancaster demonstrated half a century ago, "if one of the Paretian optimum conditions cannot be fulfilled, a second best optimum situation is achieved only by departing from all other optimum conditions" (1956, p. 12, emphasis added; see epigraph to this paper). For example, if policy makers in LA ignore crucial distortions simply because they are out of bounds (such as Asian competitors with 'distorting' trade and industrial policies, and 'distorting' pro-growth macros) and design what they - from their mainstream perspective - consider to be 'first-best' policies (and apply, for example, flexible exchange rates, a low and flat import tariff, or abandon trade and industrial policies), then the likely outcome will not even be a 'second-best'. Additionally, if policy makers in LA keep assuming that they live in a world in which the 'efficient capital market theory' rules, and continue to implement sweeping financial deregulation and full opening of capital accounts (as if all that mattered in financial markets were market discipline and self-regulation), the likely outcome would be even more financialisation, overvalued exchange rates, and so on. That is, rather than an outcome that is a 'first-best' scenario, it is more likely that there will be one visited by 'first-class' financial crises. ${ }^{46}$

45 In the case of the N-2 countries, for example, the ('non-maquila') production of manufacturing components for export to China has had a significant effect in this direction (Palma, 2009b).

46 It is quite remarkable how in LA financial policy is still inspired by the 'efficient capital markets hypothesis'; i.e., it is still devised assuming that in financial markets prices at all times "fully reflect" all available information, so that there cannot be an endogenous gap between market prices and fundamentals, let alone a bubble. And that stock markets would always 'self-correct', because stock prices are supposed to be a 'random walk' i.e., in stock markets there is no scope for profitable speculation (especially under risk neutrality) because smart market players would simply force stock prices to become rational (by taking the other side of trades if prices begin to develop a pattern, as this is bound to have no substance). In other words, for the efficient market theology a 'rational 
Surely it is time to realize that free trade, Ricardian comparative advantages, fully open capital accounts, 'flexible' exchange rates, 'independent' monetary policy, regressive taxation, liberalized finance, economies on automatic pilot and policy 'neutrality', and so on may well be (from a logical point of view) internally coherent in mainstream power-point models, but in the real world these policies do not lead to sustainable growth. Although there is little doubt that the alternative scenario of pro-growth macros, strategic trade and industrial policies, coordination of investment, capital controls, progressive taxation, a competent educational and training system that encourages the acquisition of productive capability, and so forth are challenges as big as they come, why should it be that only low- and middle-income Asian countries are capable of mastering this complex course of action effectively? Perhaps LA's 'purity of belief' is just an excuse for not even trying...

To summarize, from the perspective of their own mainstream economic thinking, perhaps the main problem with LA's neo-liberal economists (of all political denominations) is how a rigid ideology seems to constrain their core policy-making from moving beyond a virtual world of 'first bests'. As a famous Chicago-trained economist said in a recent interview in Chile, the main problem with Latin American market fundamentalists is "...that [their] ideology ... is blind to the common sense." 47

\section{7.- Manufacturing as a faltering engine of growth due to Latin America's premature de-industrialisation}

It's hard to believe today that during the 1960s and 1970s LA was the undisputed manufacturing powerhouse of the South, responsible for nearly three of every four dollars of manufacturing value-added generated there (Figure 21, left-hand panel). Although its share began to fall in the 1970 s due to some inevitable catching-up from late-starters, this process accelerated after 1980 in such a way that by 2008 LA's share represented just one-fourth of the total - and adding Taiwan to East Asia (not included in the WDI database), just one-fifth. As South Asia has kept its share almost intact, and as Sub-Saharan Africa represents a small (and declining) proportion of the total, what was really going on was a switching of position between LA and East Asia. That is, when the inevitable catching-up from Asian late-starters began to take place properly, LA, instead of putting up a fight, threw in the towel...

surfer' is not one who has fun riding waves, but one who gets drowned trying to create undertows!

47 See interview with Martin Carnoy, Professor of Economics and Education at Stanford University, June 2010, in http://www.elmostrador.cl/noticias/pais/2010/06/24/\%E2\%80\% 9 Cla-competencia-en-educacion-es-una-locura-de-la-derecha\%E2\%80\%9D/. For his paper on Chile, see www.stanford.edu/dept/SUSE/ICE/pdfs/Chilepaper.pdf. 
FIGURE 21
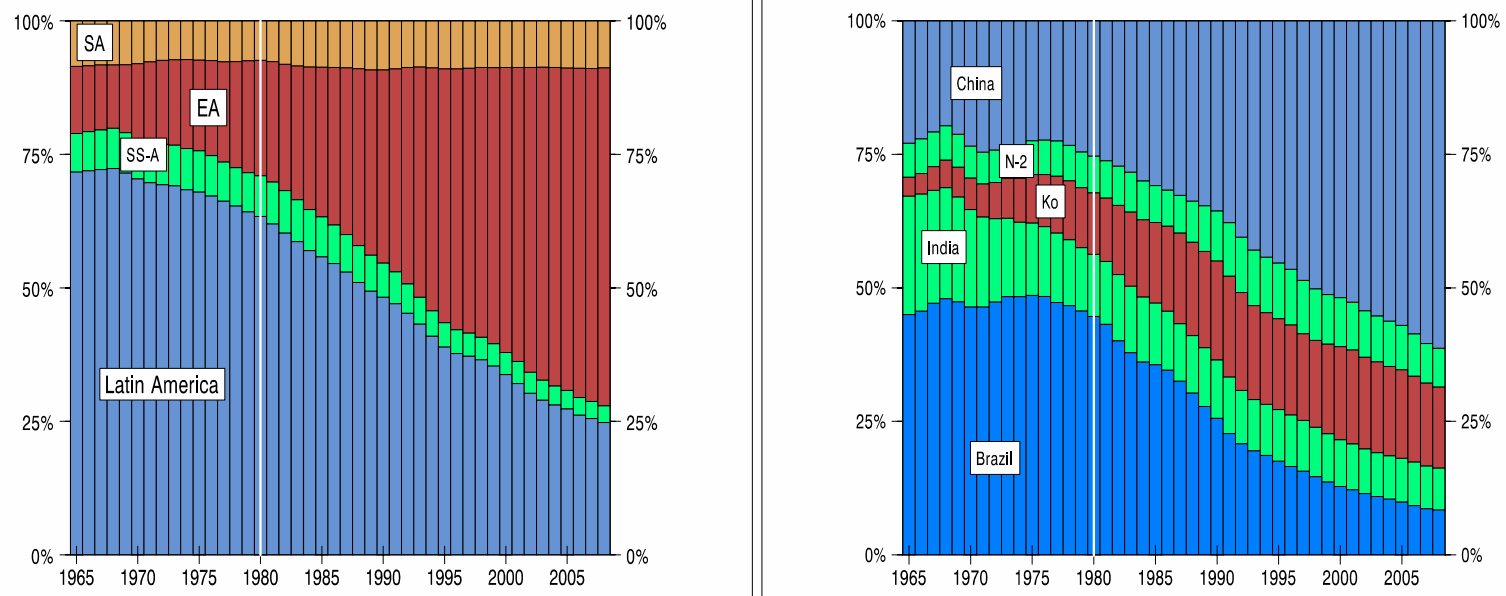

- Regions according to WDI definitions; DCs = developing countries; and $\mathbf{N}-\mathbf{2}=$ Malaysia and Thailand.

- Source: WDI (2010; data are only available from 1965 for most countries and regions).

LA's relative decline is particularly acute in the case of Brazil (right-hand panel). By the mid-1970s Brazil's manufacturing output (US\$ 56 billion) was almost identical to the combined output of China, India, Korea, Malaysia and Thailand (US\$ 57.8 billion). By 2008 its manufacturing output (US\$ 121 billion) was equivalent to less than $10 \%$ the combined output of the other 5 Asian countries (US\$ 1.4 trillion; WDI, 2010; data in constant 2000-US\$). This turnaround took place because while Brazil's manufacturing output grew at roughly the same pace as the combined output of these Asian countries between 1965 and 1980 (9.5\% and $9.2 \%$, respectively), between 1980 and 2008 it did so at just one fifth the Asian rate $(1.9 \%$ and $9.8 \%$, respectively $-2.1 \%$ and $10.1 \%$ for the post -1990 economic reform period). In other words, while the combined manufacturing output of the five Asian countries continued to grow at roughly the same pace after 1980 as it had done previously (9.2\% and $9.8 \%$, respectively), Brazil's rate collapsed by four fifths (from $9.5 \%$ to just $1.9 \%$ ). Perhaps this remarkable process of de-industrialisation is what the President of the Brazilian Central Bank wanted to unleash when he declared in 1996 (see introduction) that the main aim of the economic reforms in his country was 'to undo forty years of stupidity'...

In turn, Figure 22 shows the relationship between the growth of manufacturing and that of non-manufacturing GDP since 1990. 
Growth of manufacturing and non-mf GDP in three developing regions, 1990-2008

\section{[Y] growth of non-mf GDP}

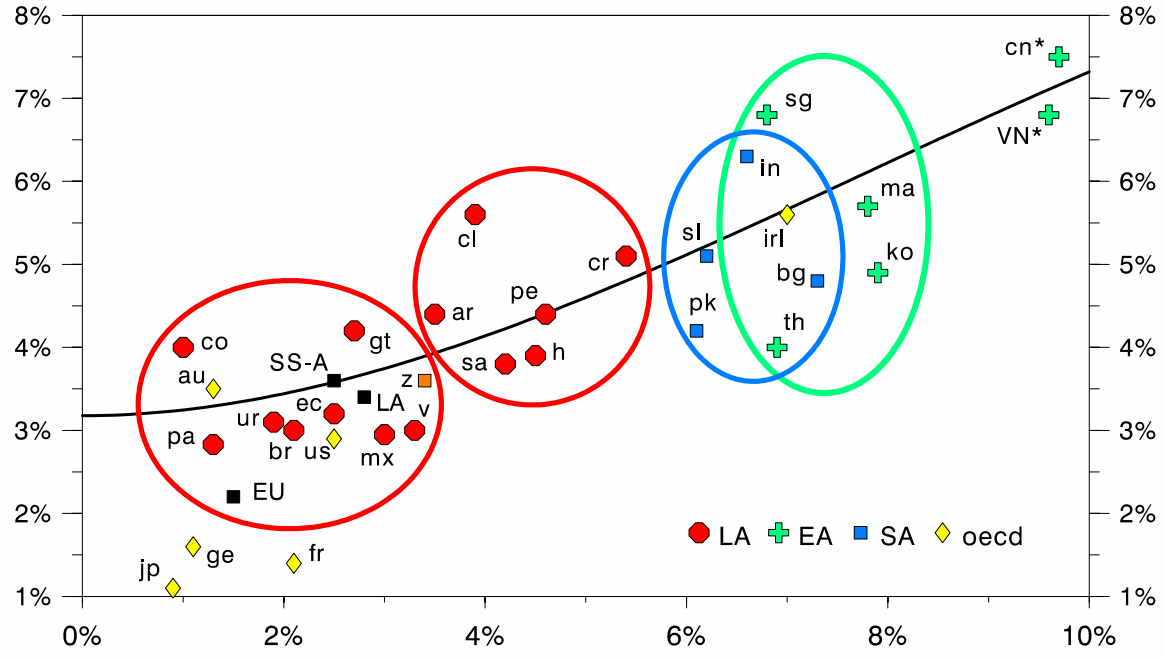

[X] growth of manufacturing output

- $[\mathbf{Y}]=$ vertical axis; and $[\mathbf{X}]=$ horizontal axis. $\mathbf{m f}=$ manufacturing.

- Regions: SS-A = Sub-Saharan Africa (excluding South Africa).

- Countries: acronyms as Figure 2 and 12 ; and $\mathbf{c n}^{*}=$ manufacturing growth of China $=$

$12.3 \% ; \mathbf{h}=$ Honduras; $\mathbf{f r}=$ France; $\mathbf{g e}=$ Germany $; \mathbf{p k}=$ Pakistan; $\mathbf{v}=$ Venezuela; $\mathbf{V N}$ * $=$ manufacturing growth of Vietnam $=11.2 \%$; and $\mathbf{z}=$ South Africa (1994-2008). There are negative intercept and slope dummies for the EU, Eastern Europe, and Sub-Saharan Africa not shown in the graph.

- $\mathrm{R}^{2}=71 \%$; all variables are significant at the $1 \%$ level (see Palma, 2010).

- Source: WDI (2010; some Eastern European countries only have data available from 1995). For Ireland, UN (2010), and for Taiwan, Taiwan (2010).

In manufacturing (unlike in exports) LA is best represented by the base regression (i.e., there is no significant Latin American dummy): generally poor performance in manufacturing is linked to similarly poor performance in GDP as opposed to the EU, Eastern Europe and Sub-Saharan Africa, where their even poorer performance in manufacturing generate three different negative regional dummies. As in exports, there is a slightly better cluster made up of Argentina, Chile, Costa Rica and Peru (this time followed by the 'maquila' countries of Honduras and El Salvador). In addition, the most robust specification for this relationship tends to confirm 'Kaldorian' dynamic increasing returns in manufacturing; that was not the case for the (linear) export regression.

Together with low rates of investment (including in services and infrastructure) and lack of upward export capacity diversification, there is little doubt that the remarkable neglect of manufacturing since economic reforms lies at the heart of LA's productivity problem, especially its long-term sustainability.

Finally, Figure 23 builds on my previous work on de-industrialisation (Palma, 2005b, and 2008), this time using an imaginative de-composition methodology (Tregenna, 2009), which disaggregates the changes in the share of 
manufacturing employment into its three main components - the economy-wide labour productivity, the share of manufacturing in GDP, and the labour intensity in manufacturing (i.e., the inverse of labour productivity).

\section{FIGURE 23}

\section{Latin America: the neglect of manufacturing and the post-1980 process of de-industrialization}
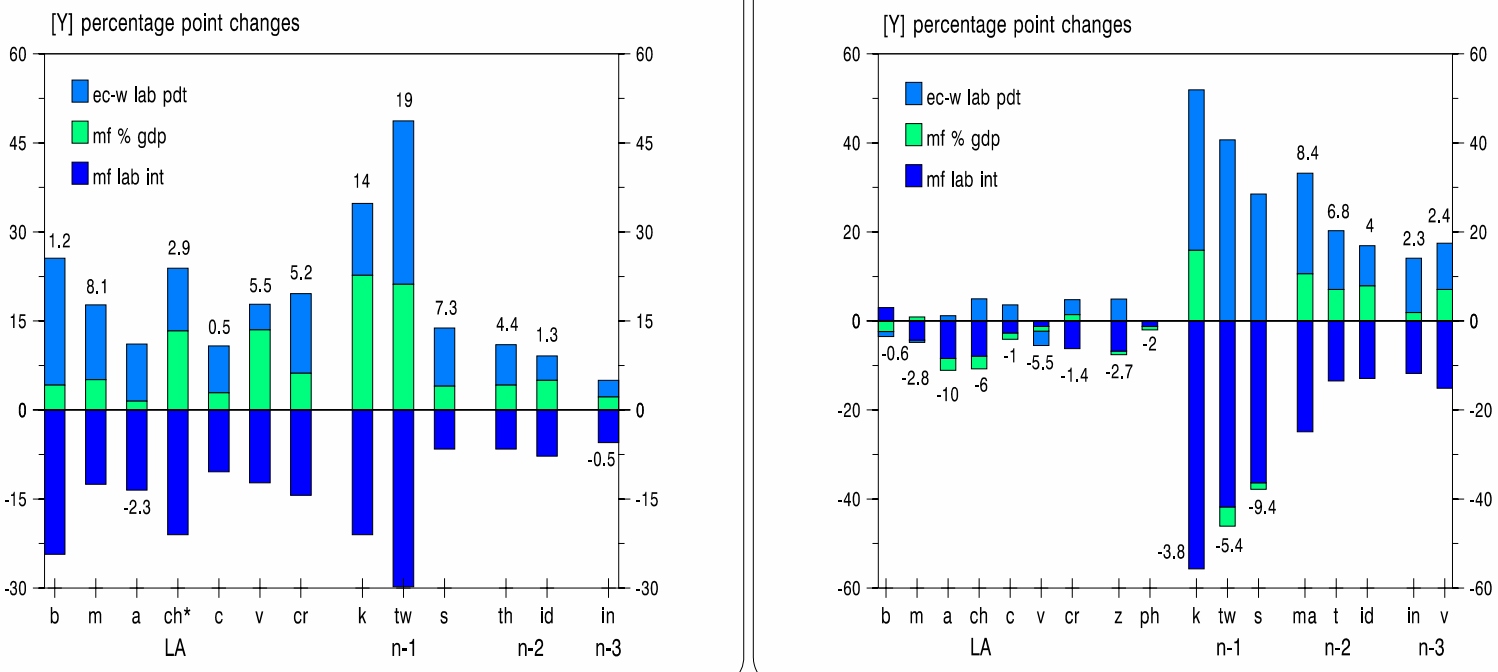

- $[\mathbf{Y}]=$ vertical axis; and $[\mathbf{X}]=$ horizontal axis. $\mathbf{m f}=$ manufacturing. ec-w lab pdt $=$ economy-wide labour productivity; $\mathbf{m f} \% \mathbf{~ g d p ~ = ~ t h e ~ s h a r e ~ o f ~ m a n u f a c t u r i n g ~ i n ~ G D P ; ~} \mathbf{m f}$ lab int = labour intensity in manufacturing (the inverse of labour productivity).

Percentages shown above each bar are the overall percentage change in the share of manufacturing in total employment (the net effect of the three processes at work); when the figure is negative, the percentage is shown below the bar.

- Countries: acronyms as Figure 2, 8 and 13, and ch* = Chile (1950-73); Malaysia and Vietnam are excluded from the left-hand panel due to lack of data on manufacturing employment.

- Sources: for manufacturing output, WDI (2010). For Taiwan, Taiwan (2010). For manufacturing employment, GGDC (2007) and ILO (2010). Tregenna (2009) was used for the methodology in the 'three-way decomposition' analysis.

The main findings in Figure 23 are: first, with the exception of Argentina, between 1950 and 1980 changes in the share of employment in manufacturing were all positive, and were the outcome of large changes in its three components. These changes were not as large as those of Korea and Taiwan, but were larger than those of Singapore, Thailand, Indonesia and India (see left-hand panel). Second, that LA's overall post-1980 decline in the share of manufacturing employment are similar to those of much more advanced, much higher income per capita, $\mathrm{N}-1$ economies (as opposed to the positive changes that took place in Asian countries with more similar levels of income per capita - the $\mathrm{N}-2$; see negative figures below the bars in the right-hand panel). Third, LA's post-1980 decline in the share of employment in manufacturing, although similar in size to those in the $\mathrm{N}-1$ countries, was the result of forces of a very different nature. The remarkably small change in the three components of manufacturing employment after trade liberalisation and neo-liberal reforms suggests that LA adopted a type of 'standing still' defensive strategy in this respect. And fourth, as 
the evidence of the right-hand panel particularly suggests, that rather than referring just to the 1980 s as the 'lost decade', as far as manufacturing is concerned (and with few exceptions, as EMBRAER) in LA the three post-1980 decades might well deserve that label. ${ }^{48}$

Part of the post-reform problem with LA's manufacturing, of course, was due to the nature of the ISI's legacy. ISI's rigid system of protection (in highlyincome-unequal domestic markets) resulted in many distortions, as incentives inevitably led to horizontal diversification because there were more rewards for developing new products than for productivity 'deepening'. In this sense, despite its discourse, ISI did not really have a proper 'infant industry' agenda because its logic was not one of temporary protection to help - and push - firms to get to the frontier and become internationally competitive (Pérez, 2008; Díaz-Alejandro, 1989; and Fajnzylber, 1990). Rather, often supposedly 'infant' corporations (eg. General Motors, ITT, General Electric, Bayer or Nestlé) ended up protected with effective rates that sometimes reached four-digits. In fact, there was actually a 'double play': with big exceptions (as the already mentioned case of EMBRAER indicates), the manufacturing industry that emerged from ISI found it particularly difficult to adjust to the new open paradigm and the surge of Asia. This was made worse by the speed taken by trade liberalisation, and the unnecessary difficulties and distortions created by monetarist-macros. But what developed around ISI (including institutions, suppliers and skills) was considerable. ${ }^{49}$

After trade liberalisation LA's (relatively fragile) manufacturing not only had to adapt hastily to a new tough internationally competitive scenario, but it had to face two further problems. On the supply side, it had to struggle against an Asian "double-squeeze". On the one hand (and as mentioned above), as labour-intensive techniques in manufacturing had been mastered in low-income Asia - where wages are even lower, labour is in abundance, and exchange rates and interest rates are kept "artificially" at levels which are both stable and competitive - LA found it particularly difficult to compete in low-wage, labourintensive, small-profit-margins manufacturing (except when its geographical location and US's trade treaties created distortions that favoured 'maquila' activities). On the other, LA's manufacturing also found it difficult to compete with technologically-complex, rapid-product-evolving manufacturing production from high-middle income Asian countries, with their huge investment rates, effective trade and industrial polices, 'pro-growth' macros, and outstanding technological-absorpting capabilities. ${ }^{50}$ From this perspective, what is particularly difficult to understand is what little effort was made by Latin American countries to develop the obvious manufacturing niche available to them: the up and downstream manufacturing activities associated with commodity extraction and processing. ${ }^{51}$

To summarise, LA's post-economic reform 'policy neutrality' attitude regarding manufacturing (despite the huge distortions in world trade in

\footnotetext{
48 According to a senior manager of one of the major retail outlets in Chile, nearly $90 \%$ of manufacturing products currently sold in his department store are imports (see http://diario.elmercurio.com/2010/06/23/economia_y_negocios/economia_y_negocios/ noticias/35E59938-CA53-43F2-8571-088B44D979E5.htm?id $=\{35 E 59938-C A 53-43 F 2-$ 8571-088B44D979E5\}).

49 Unfortunately, ISI was not allowed to transform the region's political configuration either (as a normal process of industrialisation would have done) - military regimes put a stop to that.

50 For three views on the rise of Asia, see Amsden (2001), Chang (2006), and Khan (2001). See also Cimoli, Dosi and Stiglitz (2009). See also Ferguson (2011).

51 See Walker and Jourdan (2003), and Palma (2009b).
} 
manufacturing) happened because supposedly 'the markets-always-know-best'; this led to a process of premature de-industrialisation without an end in sight. In other words, the naïve attitude of "let's assume that all the Paretian optimum conditions are fulfilled" (including a level playing field in international trade in manufacturing) has led to the supposed 'first-best' policies in this respect. LA's 'manufacturing-catching-up-in-reverse' (Figures 17 and 18), LA's huge relative decline in its share of manufacturing output in the South (Figure 21), and the remarkably small change in the three components of manufacturing employment after neo-liberal reforms (Figure 23) should then not come as a surprise; nor should the lack of a sustainable engine of growth, or the productivity slowdown. In Brazil not even an institution such as BNDS has been able to do much about it.

Added to this, on the demand side, Latin American-style neo-liberal capitalism has been characterised by a chronic deficiency of effective demand for its non-commodities tradable sector, especially manufacturing. This has been the direct outcome of the 'deadly triad' of undervalued labour, overvalued exchange rates (backed up by high interest rates), and 'sterilised' governments. These are, respectively, the direct outcome of 'flexible' labour markets, open capital accounts with 'tough' monetarist macros, and governments with their hands

(institutionally) tied in terms of implementing effective counter-cyclical action and pro-active public investment. ${ }^{52}$

In other words, in post-reform LA there is not much evidence in manufacturing of the characteristics that have been associated in the mainstream literature with 'high-imagination-enabling-countries' (Friedman, 2007). Rather, evidence (particularly that in the right-hand Panel of Figure 23) points towards countries whose manufacturing sector have been (defensively) in 'hibernation'.

\section{8.- Conclusions}

In the economic literature there are three different analytics of growth, but only in one is growth analysed as a 'sector-specific' phenomenon (the structuralist/ Post Keynesian/heterodox tradition; see Palma, 2005b, and 2008). From this perspective, LA's abysmal TFP-record wells after economic reform should make those who believe otherwise think again. In particular, how can those in the Washington Consensus - with their emphasis on 'getting the prices right' and 'getting the institutions right' - explain that after two decades of putting into practice open capital accounts, free trade, balanced public accounts, well defined and enforced property rights, independent central banks and so on (i.e., well after having set the Latin American economies on automatic pilot and policy neutrality), LA's TFP record can still only be described as appalling? ${ }^{53}$ And the well-rehearsed argument that what is needed is yet more of the same sounds increasingly hollow.

\footnotetext{
52 According to a Goldman Sachs analyst, Brazil's real is currently the world's most overvalued major currency (see http://www.bbc.co.uk/news/business-11424864). In the same spirit, perhaps Brazil's current growth acceleration is the world's most overrated boom! In turn, in the October 'Economist's Big Mac index' the real comes second (after the Swiss Franc) in terms of degree of overvaluation - $42 \%$ vis-à-vis its 'Big Mac PPP level' (or the exchange rate that would mean hamburgers cost the same in the US as in Brazil); see http://www. economist.com/node/17257797?story_id=17257797.

53 Not much evidence in LA, though, of even an attempt at 'getting the social capital right'. But this was never really part of the neo-liberal blueprint. As Mrs. Thatcher famously made it clear, from a neo-liberal perspective "there is no such a thing as society, just individuals."
} 
Perhaps the main lesson from LA's experiment with neo-liberal reforms is that the Washington Consensus is just one of the many heaps of ideological recipes still waiting for a theory relevant to the real world (or a bonfire...). How can it explain why so many in Asia do things 'wrong' (sometimes very 'wrong') but develop fast, while LA does almost everything 'right' (and with so much 'credibility', and scoring so high in the usual indices, such as those of 'economic freedom', 'competitiveness', and so on) but can only achieve a low-intensity growth dynamic - with all its difficulties in creating, let alone sustaining productivity growth? And why is it that the 'invisible hand' does not know how to break this low-intensity growth dynamic? When Keynes said that people usually prefer to fail through conventional means rather than to succeed through unconventional ones, he could not have guessed just how accurately his remarks would define LA today.

So, most of Asia gets a capitalism that is pretty unsavoury (with all its contradictions, unfairness and excuses), but one that at least is capable of developing many of the productive forces of society (despite the fact that financial markets, and sometimes also policy makers, often insist in forging ahead in the wrong direction). ${ }^{54}$ LA, meanwhile, gets a neo-liberal brand of 'sub-prime' capitalism which is not even able to offer much productivity growth - i.e., as mentioned above, LA gets the cloud without the silver lining. This is mostly due to an elite that does not want to know what capitalism is really about, and a bunch of highly-trained economists who still believe that when it comes to policy making the first commandment is that one has to stick to the 'first-best'.

From the latter perspective, perhaps the key difference between LA and many countries in Asia is that policy-makers in the former still believe that the Washington Consensus is a set of ingenious tricks devised by Dumbledore, while the latter instinctively know that they actually are the work of Voldemort...

Apparently, in LA market capitalism is a system in which only workers and small firms continuously have to struggle to improve their performance just to survive; for big capital the rules of the game are more agreeable. What the new neo-liberal paradigm seems not to grasp is that it is one thing to implement reforms in order to create market opportunities, but quite another to ensure that there are sufficient market compulsions to guarantee that these opportunities are taken up. ${ }^{55}$ As a result, LA's brand of capitalism is characterised as much by its capacity to generate market opportunities as by its ability to waste them. What LA urgently needs today is new institutions to help create both the required

54 India, for example, is an extreme example of this. It has had 30 years of remarkably rapid GDP-growth, leading to a near six-fold increase in output. However, on the one hand, financial markets and policy makers are increasingly leading the economy into a rapid process of financialisation (with the inevitable bubbles and growing financial fragilities); and on the other, nowhere is more evident the failure of capitalist economic growth to improve the well-being of the majority of the population. In fact, according to the Multidimensional Poverty Index (an index that measures the 'deprivations' in households - from education and health to assets and services - just eight Indian states still account for more poor people than the 26 poorest African countries combined (421 million). Furthermore, the 'intensity' of the poverty in many parts of India is still today (after 30 years of rapid growth) much worse than that in Sub-Saharan Africa (see http://www.ophi.org.uk/policy/multidimensional-poverty-index/). The latter phenomenon has made the study of India's rapid economic growth much more difficult because many analysts (at home and abroad) have tended to confuse a well-founded socialist critique of India's capitalist development with the concrete analysis of how capitalism has been able to develop many of the productive forces there (on its own terms, 'warts and all') - for example, the average labour productivity has increased three-fold since 1980 - what a difference with LA! (see GGDC, 2010).

55 Wood (2002) and Khan (2005). 
capabilities and the necessary compulsions for productivity growth, especially those that would help to 'discipline' the capitalist elite à la EA. It also needs a new structure of property rights - including well-defined and enforced rights on skills à la Japan or Germany. ${ }^{56}$ And, of course, the ideology to back this up would also help - as Gramsci said, more often than not battles are won or lost on the field of ideology.

Added to this is the already mentioned phenomenon that Latin Americanstyle capitalism has also been characterized by a chronic deficiency of effective demand from the 'deadly triad' of undervalued labour (due to 'flexible' labour markets), overvalued exchange rates with high interest rates (due to open capital accounts and monetarist macros), and 'sterilized' governments.

In summary, the region's growth performance since economic reform may be rather disappointing (particularly in terms of productivity-growth), but Latin American-style neo-liberal capitalism became unrivalled when it came to offering world-class commodities, an abundance of (precarious, low-productivity and lowwage) jobs, stylish retail, lucrative finance, and the 'purity of belief'.

By now it should be obvious that 'flexible' labour markets do not transform an oligarchy into a proper capitalist class; even from a neo-liberal perspective surely one can have too much of a good thing. The same happens with the opening of capital accounts excessively reinforcing the domestic élite's 'highappropriation-cum-little-accumulation' distributive strategies, and its longstanding biases for mobile assets. In Brazil, for example, the 'coefficient of financialisation' - the ratio of the stock of non-monetary financial assets to the stock of productive capital - increased from $7 \%$ at the beginning of economic reform (1991) to 40\% in 2009 (See Bruno, 2010).

As discussed in detail elsewhere (Palma, 2009a and 2009c; see also Frangie and Palma, 2011), neo-liberalism may well have become the most effective technology of power ever. Perhaps the neo-liberal ideology associated with LA's post-1980 period (with its incredibly successful process of 'relegitimisation' of capital) is just shorthand for 'the art of getting away with such remarkably asymmetric distributional outcomes and political settlements within democracies.' That is, in the language of game theory, for its capacity to transform a particularly asymmetric set of distributive strategic choices, and the corresponding payoffs, into a Nash equilibrium by convincing the majority that there is no point trying to challenge these strategies while the all-too-powerful top income players keep theirs unchanged. What is particularly remarkable about neo-liberalism is its capacity to achieve this not by 'old-fashioned' forms of social conflict resolution, such as 'chicken' or 'hawk-dove' games. ${ }^{57}$ Now, neo-liberalism

56 On the necessity of adequate property rights on skills, see especially Pagano (1991).

57 'The game of chicken' is a model of conflict associated with a diverse range of social conflicts. In this game the key issue is which player yields first (or blinks first). The bestknown example takes place in the 'chicken race' in the 1955 film Rebel Without a Cause. They race stolen cars towards an abyss, and whoever jumps out of the car first loses and will be deemed a 'chicken'. Bertrand Russell also made it famous as a metaphor for the psychotically dangerous game of nuclear stalemate. This game is an 'anti-coordination' one because the shared resource is rivalrous (although non-excludable). Namely, sharing comes at a cost; i.e., it is subject to a negative externality (although in an income distribution game this does not have to be the case if the players are involved in a Marshallian 'efficiency wage' scenario - but try explaining that to a neo-liberal!) The unstable situation that characterises a game of chicken leads to a situation in which there is more than one outcome that could end up in a Nash equilibrium. In fact, in an anticoordination game of this type there are two opposite Nash equilibria corresponding each to the 'pure' strategy of each player. In this game, the strategic space for both players would be 'demand redistribution' and 'not demand redistribution' for the large-majority 
has been able to achieve this Nash equilibrium mostly by ideological conviction. In other words, there seems to be no longer any need for neo-liberals to threaten the majority credibly with the idea that they have too much to lose and little chance of winning by challenging the top player's strategy. Now, by ideologically convincing the majority that neo-liberalism is the only workable game in town (or, in Mrs. Thatcher's terms, that "there is no alternative"), the capitalist élite can now get away with such a remarkably asymmetric distributional outcome through a spontaneous consensus type of hegemony (in the Gramscian sense). ${ }^{58}$ As a result, (with the exception of some Central American countries that insist on behaving like Banana Republics, such as Honduras) military regimes - as a hedge against a distributional challenge by the majority - have become (temporarily?) obsolete.

The key point here is that there is a big difference between the great majority entering into such an unfavourable Nash equilibrium out of having 'thrown in the towel' when faced with overwhelming odds against the likelihood of succeeding in challenging the 'pure' distributional strategy of the capitalist élite, or entering into this Nash equilibrium simply out of ideological conviction. If the latter dominates, the game would then cease to be one of 'chicken'. The astounding aspect of this most unlikely of Nash equilibria (in which the great majority is now ideologically prepared to put up with such an unequal distributive outcome as if it was just their lot in life) is that it takes place despite the obvious 'collective action' conundrum by which the majority could clearly improve their payoffs if only they could somehow believe - and agree - on a strategy different from the current one. For having achieved this most unlikely of Nash equilibria by a spontaneous consensus type of hegemony, the Latin American élite (and their friends in the 'new' left) surely deserves an entry in the 'Guinness Book of Political Records.'

However, with very few exceptions, from an economic perspective, this remarkable set of ('by ideological conviction') Nash equilibria in terms of political settlements and distributive outcomes seems only able to deliver nearly productivity-less growth and a huge process of financialisation. ${ }^{59}$ For example, in the five-year period before the global financial crisis (2002-2007) the capitalisation of LA's stock exchanges increased 10 times faster than GDP (see IMF, 2009). So (as mentioned above), in Latin American style neo-liberal capitalism commodities have the rôle of providing the foreign exchange, services the jobs, and financial markets all the fun. A rather good example of a Nash equilibrium that (although rather pleasant for the élite) is clearly not Pareto optimal.

player, and 'yield to redistribution' and 'not yield to redistribution' for the capitalist élite one. So one effective tactic in this game (relevant for this story) would be for one party to signal his or her intentions convincingly enough - i.e., it could become a game of 'brinkmanship' (a strategic move designed to avert the possibility of the opponent switching to aggressive behaviour). This is one reason why in a 'game of chicken' scenario an 'irrational' player tends to have the upper hand.

58 The bait that a Nash equilibrium of this type would be able to bring a better pay-off in the future may have been instrumental in helping the majority to swallow such an unpalatable current outcome. From this perspective the new ideology would have come about because it was able to deliver convincingly a 'free-market-are-superior' cum 'trickledown' discourse. Capital gains from multiple asset bubbles and easy access to an almost unlimited amount of credit may have helped confirm the 'trickle-down' part of the story, and facilitate sustain popular support for the free-market-supremacy discourse (despite its obvious shortcomings).

59 For an analysis of the relationship between income inequality and financialisation, see Palma (2009c). 
Perhaps, the very fact that this equilibrium has not been challenged from within is a significant ingredient in the dynamic that leads to productivity-less growth and financialisation. When Adam Smith said that 'without competition there is no progress', he was surely also referring to ideology. And as Ortega y Gasset explained, "human history is the product of discontent" (see epigraph to this paper). The UNDP may well find this model irresistible - even call it 'propoor' - because (given the nature of the Latin American capitalist élite) the alternative could well be more or less the same plus South African levels of unemployment. But (despite all the current euphoria in Brazil) there is no emerging 'tiger' in sight.

Some economists, like Rodrik (2007), have argued that in LA the contrast between the two periods (pre- and post-economic reform) is based on the fact that during ISI there were incentives to invest (industrial policies), but little market discipline due to lack of competition. In turn, during the reform period there was little incentive to invest, but a lot of market discipline. However, on the latter issue, I think the region is still waiting for the real thing - as the head of Chile's largest holding company and former President of the Confederation of Chilean Industry explains, "[t]his is a market economy in name only.

Competition has disappeared; mergers and acquisitions have led to a huge degree of oligopolistic concentration." (http:// www.atinachile.cl/node/4629). ${ }^{60}$ Moreover, one should never forget that in many countries in EA the 'market discipline' part of the story has had an added 'state discipline' component; i.e., the ability of the state to threaten non-performing companies credibly with withdrawal of subsidies.

Those in heterodox circles who like to look at the Anglophone periphery as models (i.e., Ireland and New Zealand rather than Korea or Malaysia), and argue that what LA needs to be able to replicate their pattern is an industrial policy that attracts FDI to fill the more challenging technological gaps, create 'clusters', and so on, have something to explain: how will middle-income LA ever become a dynamic capitalist endeavour without a proper domestic capitalist class (like those found in some Asian countries)? In this respect, the weakness of post-reform FDI-intensive Mexico is particularly telling. And oddly enough, many pre-1980 structuralist thinkers made the same mistake, expecting (in vain) that FDI would be the force that would transform ISI into a more export-oriented endeavour. Despite its many contributions, FDI was actually part of ISI's main problem: its anti-learning bias (Pérez, 2008). In addition, even when it was the Latin American domestic firms that had contracts with foreign companies, they normally had to import the technology and use it rigidly as it came; whenever possible, they also had to import the machinery and parts. In the early $1970 \mathrm{~s}$ Brazil may have produced more cars than the whole of developing Asia put together, but there was no Hyundai in sight...

Surely it is time to acknowledge that Latin American economies, some of them already well above the ten thousand dollar mark in per-capita PPP terms, should be perfectly capable of relying on their own resources and capabilities when dealing with their main current economic challenges. But for this to happen, two obstacles need to be overcome. The first is the one facing LA's neoliberal economists of all political persuasions: when it comes to policy making, how to abandon their 'first best' fantasy world, and stop de facto assuming 'complete markets', 'automatic stabilisers', 'efficient market hypotheses' and so on (i.e., how to give up their self-imposed rôle of 'keepers of the neo-liberal holly

60 According to a recent study, four family-groups (including that of the current Chilean President) control $47 \%$ of the assets traded in the Chilean Stock Exchange; see http:// www.emol.com/noticias/economia/detalle/detallenoticias. asp?idnoticia $=430194$. 
grail' - the only true believers) ${ }^{61}$ The second is the one facing LA's capitalist élites: how to overcome their long-standing addiction to 'low-intensity' economic life (currently so well nourished by the discreet charm of a narcissistic ideology), and acquire the Schumpeterian ambitions of some of their Asian counterparts with their Canon-style motto: 'if anybody can, we can'.

Perhaps the key difference between the Latin American and many Asian oligarchies simply boils down to the fact that while the former have 'tenure', the latter have continuously to deliver if they want to go on enjoying their power and privileges (Palma, 2011).

Alexis de Tocqueville once said that he "[could not] help fearing that men may reach a point where they look on every new theory as a danger, every innovation as a toilsome trouble, every social advance as a first step toward revolution, and that they may absolutely refuse to move at all" (quoted in Judt, 2010). Neo-liberalism (despite all the flashy virtual realities and fickle-minded euphorias) may well be leading LA into that cul-de-sac...

61 Otherwise, they should hardly complain if their zombie policy-making is sometimes described as being inspired by 'voodoo economics' (see, for example, Krugman, 2010). It is quite remarkable that in LA as well not only New Classical, but also New Keynesian economists still work within a 'complete markets paradigm', and with the strongest version of the 'efficient markets hypothesis' (for a critique, see Buiter, 2009). 


\section{References}

Acharya, A (2009), The Impact of Globalisation on International Convergence and Growth, Cambridge, mimeo.

Adorno, T (2006), Minima Moralia: Reflections From Damaged Life, Verso.

Aghion, P and P Howitt (1998), Endogenous Growth Theory, MIT Press.

Amsden, A (2001), The Rise of "The Rest": Challenges to the West from LateIndustrializing Economies, OUP.

Arantes, P 2007. Extinção, São Paulo, Boitempo Editorial.

Boix, C (2003), Democracy and Redistribution, CUP.

Bruno, M (2010), 'Growth Regimes in Brazil: periodization and macroeconomic implications', IPEA.

Buiter, W (2009), 'The unfortunate uselessness of most 'state of the art' academic monetary economics', Financial Times, March 3.

Caputo, O (2000), 'Hacia una Política Nacional del Cobre', Visiones Económicas, Mayo.

CEPAL (2010), Statistical Division, at: www.cepal.org.

Chang, H-J (2006), The East Asian Development Experience - The Miracle, the Crisis, and the Future, Zed Press.

Chang, $\mathrm{H}-\mathrm{J}$, ed. (2007), Institutional Change and Economic Development, Anthem Press and United Nations University Press.

Cimoli, M, G Dosi and J Stiglitz (eds.), (2009), The Political Economy of Capabilities Accumulation, OUP.

Cimoli, M, G Dosi, R Nelson and J Stiglitz (2009), 'Institutions and policy shaping industrial development', in Cimoli et. al. (2009).

Debrott, D (2001), 'Teoría de la Renta y Renta de Recursos Naturales', Revista Investigación y Crítica, 5.

De Soto, H (1989), The Other Path: The Economic Answer to Terrorism, Basic Books.

Di John, J (2007), 'The Political Economy of Taxation and Tax Reform in Developing Countries', in $\mathrm{H}-\mathrm{J}$ Chang (2007).

Di John, J (2009), 'Taxation as State-Building. Reforming Tax Systems for Political Stability and Sustainable Economic Growth. A Practitioner's Guide', mimeo, FIAS/The World Bank (available at http://www.ifc.org/ifce xt/fias.nsf/AttachmentsByTitle/Taxationgrowthandgovernanceprogram_tax andgovernancetaxationasstatebuilding/\$FILE/TaxationasStateBuilding.pdf).

Díaz-Alejandro, C (1989) Collected Essays, (edited by A Velasco), OUP.

Dosi, G, K Pavitt, and L Soete (1990), The Economics of Technical Change and International Trade, Harvest.

Fajnzylber, F (1990) Unavoidable Industrial Restructuring in Latin America, Macmillan.

Ferguson, N (2011), Civilization: The West and the Rest, Allen Lane.

Frangie S (2008), The Good Governance Agenda, Weak States and Economic Development, PhD thesis, Cambridge University.

Frangie S, and JG Palma (2010), 'Neo-liberalism in theory and in practice', mimeo, Beirut and Cambridge.

Friedman, T (2007), The World Is Flat: A Brief History of the Twenty-First Century, Farrar, Straus and Giroux.

Foucault, M (2004), Naissance de la Biopolitique: Cours au Collège de France, 1978-1979, Paris, Gallimard Seuil.

GGDC, (2007), Groningen Growth and Development Centre, 10-sector database, in http://www.ggdc.net/. 
GGDC, (2009), Groningen Growth and Development Centre, Total Economy Database, in http://www.conference -board.org/economics/.

Goñi, E, H López, and L Servén (2008), 'Fiscal Reform for Social Equity in Latin America', World Bank Policy Research Working Paper, No. 4487.

Hall, R and C Jones, (1999) 'Why do some countries produce so much more output per worker than others?, QJE, 114.

Hirschman, A (1982), Shifting Involvements: Private Interest and Public Action, Princeton University Press.

Hofman, AA (2000), The economic development of LA in the twentieth century, Elgar.

ILO, (2010), KILM, Sixth Edition, www.ilo.org.

IMF (2009), Global Financial Stability database, www.imf.org.

IMF (2010), WEO database, www.imf.org.

India (2010), Statistical Division, http://mospi.gov.in/.

Infante, R, A Marinakis, and J Velasco (2003), 'Minimum wage in Chile: An example of the potential and limitations of this policy instrument', ILO Employment Paper, 2003/52.

Judt, T (2010), IIl Fares the Land, Allen Lane.

Katz, J (2004), 'Market-oriented reforms, globalization and the recent transformation of Latin American innovation systems', Oxford Development Studies, Vol. 32, No. 3.

Kelvin, Lord (W Thomson), (1900), Address to the British Association for the Advancement of Science: http://www.physics.gla.ac.uk/Physics3/ Kelvin_online.

Khan, M (2004), 'Strategies For State-Led Social Transformation: Rent Management, Technology Acquisition and Long-Term Growth', ADB (available at http://mercury.soas.ac.uk/users/mk17/Docs/Strategies \%20For\%20State-Led\%20Transformation\%20Hanoi.pdf).

Khan, M (2005), 'The Capitalist Transformation', in Jomo, KS and Reinert, ES (eds.), The Origins of Development Economics, Zed.

Khan, MH and S Blankenburg, (2009), 'The political economy of industrial policy in Asia and Latin America, in Cimoli et. al. (2009).

Krugman, P (2010), 'Redo That Voodoo', at http://www.nytimes.com/2010/07/ 16/opinion/16krugman.html?_r=1.

Lagos, JF (2000), 'Chile, de Exportador de Cobre Refinado a Gran Exportador de Concentrados: ¿la segunda fase exportadora?', mimeo, Santiago de Chile.

Lipsey, RG and K Lancaster (1956), 'The General Theory of Second Best', The Review of Economic Studies, 24(1)

Moguillansky, G (1999), La Inversión en Chile: ¿el fin de un ciclo en expansión?; Fondo de Cultura Económico.

Nelson, R (1956), 'A Theory of the Low Level Equilibrium Trap in Underdeveloped Economies', AER, May.

Ocampo, JA (2004), Reconstruir el futuro: Globalización, desarrollo y democracia en América Latina, ECLAC.

Ocampo, JA (2005), Beyond Reforms, Structural Dynamics and Macroeconomic Vulnerability, Stanford University Press.

Ocampo, JA, C Rada and L Taylor, (2009 ), Growth and Policy in Developing Countries: A Structuralist Approach, Columbia University Press.

Oliveira, F de 2006. Lula in the Labyrinth, New Left Review, 42(November).

Ortega y Gasset, J (1918), 'Impresiones de un viajero', Hebe, 5.

Pagano, U (1991), 'Property Rights, Asset Specificity, and the Division of Labour under Alternative Capitalist Relations', Cambridge Journal of Economics 15(3). 
Palma, JG (2005a), 'The six main stylised facts of the Mexican economy since trade liberalisation and NAFTA', Journal of Industrial and Corporate Change, December.

Palma, JG (2005b), 'Four sources of de-industrialisation and a new concept of the Dutch Disease', in JA Ocampo (2005).

Palma, JG (2006), 'The 1999 financial crisis in Brazil: "macho-monetarism" in action', Economic and Political Weekly, 41(9).

Palma, JG (2008), De-industrialisation, premature de-industrialisation and the Dutch disease, in The New Palgrave Dictionary of Economics, 2nd edn., Palgrave.

Palma, JG (2009a) Why did the Latin American critical tradition in the social sciences become practically extinct?, in Blyth, M. (ed.) The Handbook of International Political Economy, Routledge.

Palma, JG (2009b), Flying-geese and waddling-ducks: the different capabilities of East Asia and Latin America to 'demand-adapt' and 'supply-upgrade' their export productive capacity, in Stiglitz, JE, M Cimoli and G Dosi (eds.), Industrial Policy in Developing Countries, OUP.

Palma, JG (2009c), 'The Revenge of the market on the rentiers: why neo-liberal reports of the end of history turned out to be premature', Cambridge Journal of Economics 33(4). An extended version can be found in http://www.econ.cam.ac.uk/dae/repec/cam/pdf/cwpe0927.pdf.

Palma, JG (2010), The Latin American Economies since 1980, mimeo.

Palma, JG (2011), Homogeneous middles vs. heterogeneous tails, and the end of the 'Inverted-U': the share of the rich is what it's all about, Development and Change 42(1).

Pérez, C (2002), Technological Revolutions and Financial Capital, Elgar.

Pérez, C (2008), 'A Vision for Latin America: a resource-based strategy for technological dynamism and social inclusion', Globelics WP No.WPG0804.

Pesaran H, NU Haque and S Sharma (2000), 'Neglected heterogeneity and dynamics in cross-country savings regressions', in J Krishnakumar and E Ronchetti, (eds.) Panel Data Econometrics-Future Direction, Elsevier Science.

Quantec, 2009), South African Standardised Industry Database, http://www. quantec.co.za/data/easydata-rsa-regional-indicators.

Robinson, WI (2008), Latin America and Global Capitalism, Johns Hopkins.

Rodrik, D (2007), One Economics, Many Recipes: Globalization, Institutions, and Economic Growth, Princeton University Press.

Sodré, I (2009), 'Imparadised in hell', mimeo, London.

Taiwan (2010), National Statistics, http://eng.stat.gov.tw/mp.asp?mp $=5$.

Taylor, L (2010), Maynard's Revenge: Keynesianism and the Collapse of Free Market Macroeconomics, Harvard University Press, forthcoming.

Trần Văn Thọ, Nguyênn Ngọc Đức, Nguyên Văn Chỉnh, and Nguyên Quán (2000), Kinh té Việt Nam 1955-2000, Nhà xuát bản Thông Kê.

Tregenna, F (2009), 'Characterising deindustrialisation', Cambridge Journal of Economics 33(3).

WB (2002), Investment as a share of GDP, http://www.worldbank.org.

WDI (2010), World Development Indicators, www.worldbank.org.

Waissbluth, M (2010), Se Acabó el recreo. La desigualdad en Educación, Debate.

Walker, M and P Jourdan (2003), 'Resource-based sustainable development: an alternative approach to industrialisation in South Africa', Minerals \& Energy - Raw Materials Report, 18(3).

Wood, EM (2002), The Origins of Capitalism: A Longer View, Verso. 